\title{
Suppressing Foreign Terrorist Fighters and Supporting Principled Humanitarian Action: A Provisional Framework for Analyzing State Practice
}

\section{Citation}

Jessica Burniske, Dustin Lewis \& Naz Modirzadeh, Suppressing Foreign Terrorist Fighters and Supporting Principled Humanitarian Action: A Provisional Framework for Analyzing State Practice, Harvard Law School Program on International Law and Armed Conflict, Counterterrorism and Humanitarian Engagement Project, Research Briefing (Oct. 14, 2015).

\section{Permanent link}

http://nrs.harvard.edu/urn-3:HUL.InstRepos:25122631

\section{Terms of Use}

This article was downloaded from Harvard University's DASH repository, and is made available under the terms and conditions applicable to Other Posted Material, as set forth at http:// nrs.harvard.edu/urn-3:HUL.InstRepos:dash.current.terms-of-use\#LAA

\section{Share Your Story}

The Harvard community has made this article openly available.

Please share how this access benefits you. Submit a story.

\section{Accessibility}




\section{SUPPRESSING FOREIGN TERRORIST FIGHTERS AND SUPPORTING PRINCIPLED HUMANITARIAN ACTION}

\section{A Provisional Framework for Analyzing State Practice}

Jessica Burniske and Dustin A. Lewis, with Naz K. Modirzadeh

Harvard Law School Program on International Law and Armed Conflict

Counterterrorism and Humanitarian Engagement Project

Research Briefing + Appendix October 2015

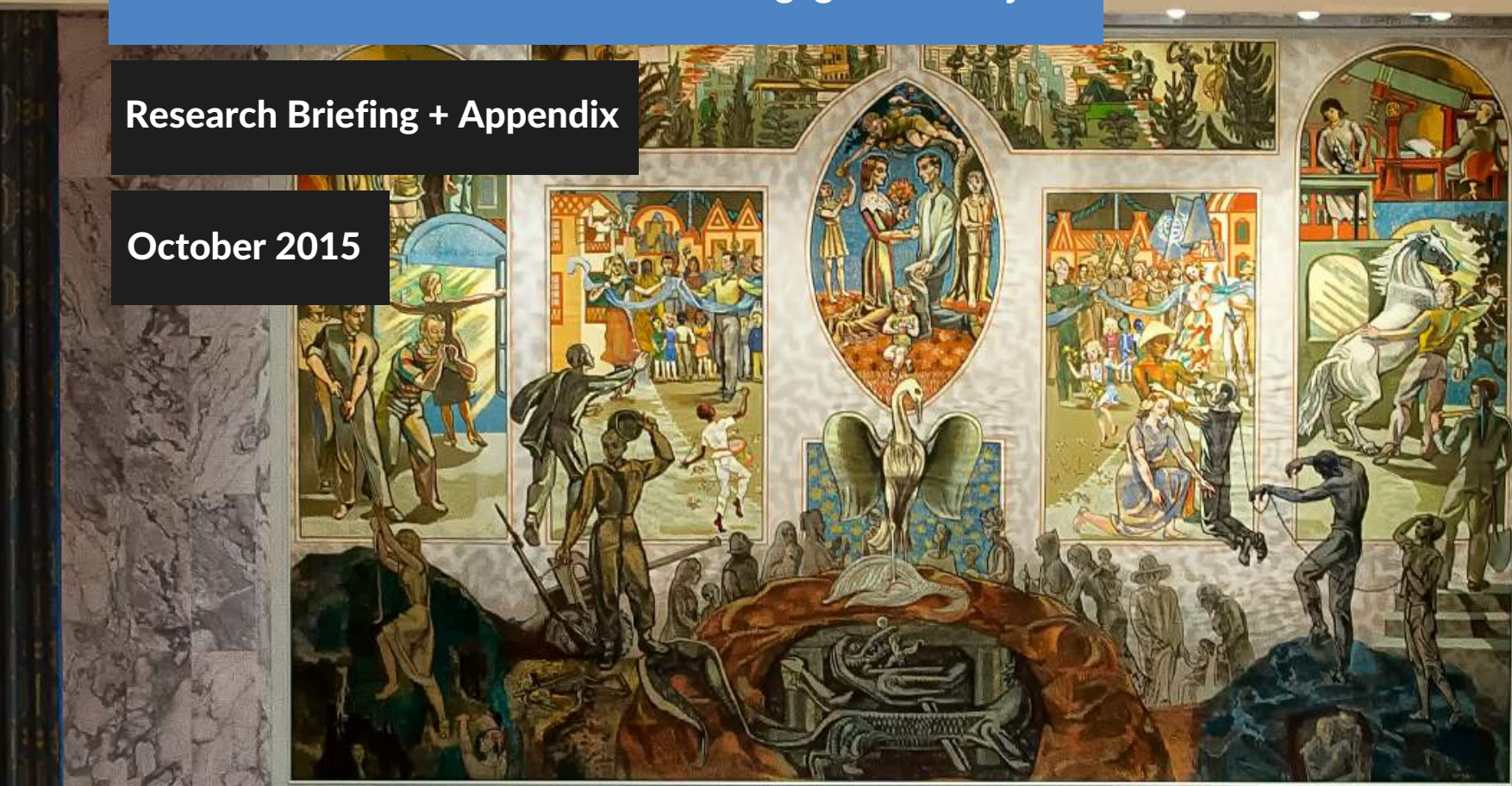

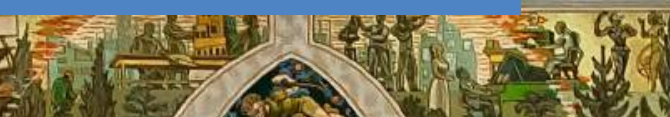

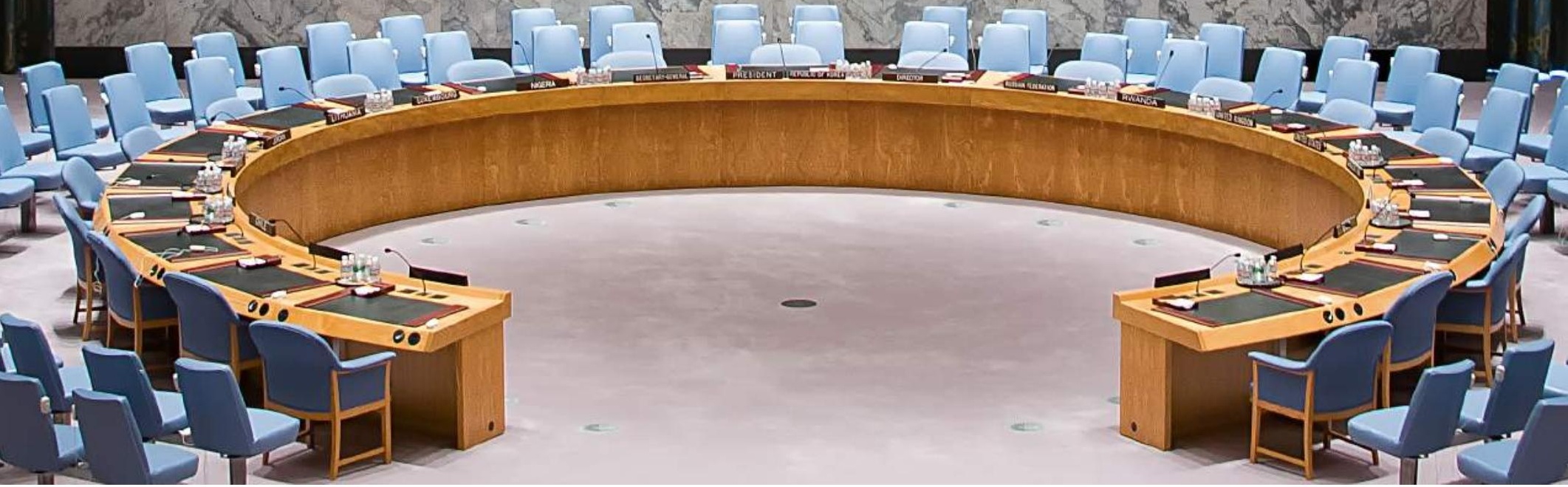




\section{SUPPRESSING FOREIGN TERRORIST}

\section{FIGHTERS AND SUPPORTING}

PRINCIPLED HUMANITARIAN ACTION

A PROVISIONAL FRAMEWORK FOR

ANALYZING STATE PRACTICE 


\title{
EXECUTIVE SUMMARY
}

\section{THE RISING THREAT OF "FOREIGN TERRORIST FIGHTERS"}

\author{
“" \\ The "unprecedented flow of foreign fighters in recent years \\ to and from conflict zones" provided the impetus for \\ Resolution 2178.
}

-President Obama (Sept. 24, 2014)

In 2014, reports suggested that a surge of foreign jihadists were participating in armed conflicts in Syria, Iraq, and elsewhere. The United Nations Security Council responded by imposing in Resolution 2178 (2014) an array of obligations on member states to counter the threat posed by "foreign terrorist fighters" (FTFs). In the intervening year, those states have taken a range of actions - though at various speeds and with varying levels of commitment-to implement the FTF obligations imposed by the Council.

\section{Proportional Distribution of Reported Foreign Fighters by Nationality for 25 Selected States*}

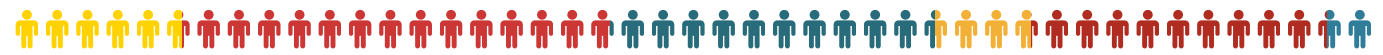

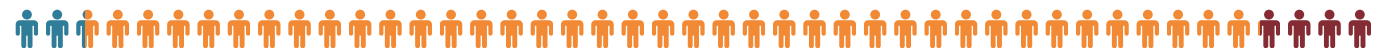

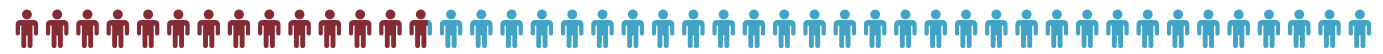

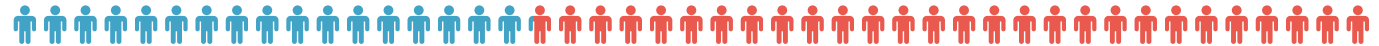

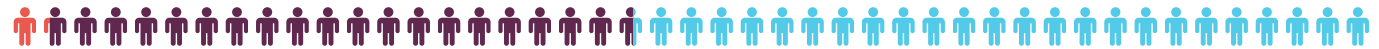

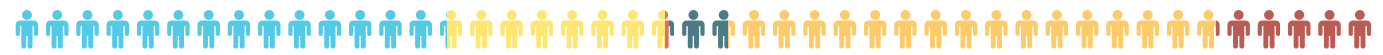

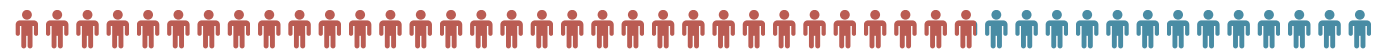

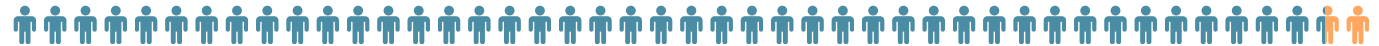

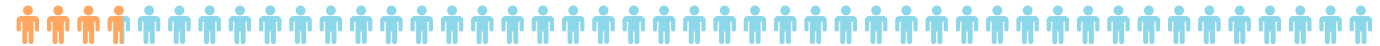

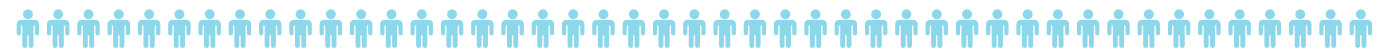

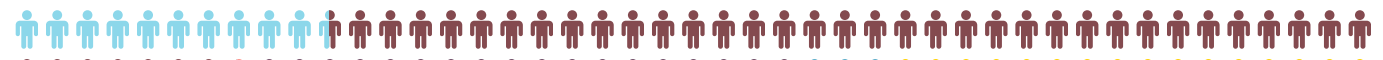

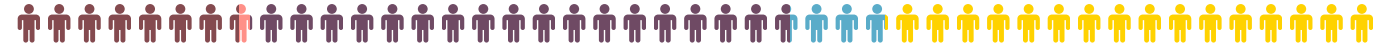

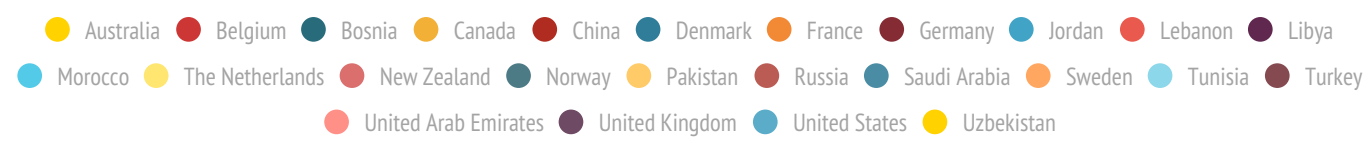

* Figures of foreign fighters came principally from International Centre for the Study of Radicalisation and Political Violence (January 26, 2015), available at http://icsr.info/2015/01/foreign-fighter-total-syriairaq-now-exceeds-20000-surpasses-afghanistan-conflict-1980s/, although for three states we had to find the numbers in other sources (e.g., news articles). Where an estimated range was given for a state, we added the range of estimates (the high and low figures) together and divided that combined figure in half to produce the estimate for that state. 


\section{SUPPORTING PRINCIPLED HUMANITARIAN ACTION IN COUNTERTERRORISM CONTEXTS}

Meanwhile, many states continue to fund and otherwise throw their support behind life-saving humanitarian relief for civilians in armed conflicts around the world-including conflicts involving terrorists. Yet, in recent years, members of the humanitarian community have been increasingly aware of the real, perceived, and potential impacts of counterterrorism laws on humanitarian action. Part of their interest stems from the fact that certain counterterrorism laws may, intentionally or unintentionally, adversely affect principled humanitarian action, especially in regions where terrorist groups control territory (and thus access to civilians, too). The effects of these laws may be widespread - ranging from heightened due diligence requirements on humanitarian organizations to restrictions on travel, from greater government scrutiny of national and regional staff of humanitarian organizations to decreased access to financial services and funding. Counterterrorism measures may also in principle give rise to a "chilling effect" on humanitarian action. That is, humanitarian actors may choose not to undertake life-saving relief schemes that they otherwise would due to fears of violating counterterrorism laws and policies.

\begin{tabular}{c} 
States should "exclude from the ambit of \\
[counterterrorism] offences activities that are \\
exclusively humanitarian and impartial in \\
character and are conducted without adverse \\
distinction [...]." \\
-International Committee of the Red Cross, 2011 \\
\hline
\end{tabular}

Given the awareness of the risks of counterterrorism laws and regulations to humanitarian action by the time Resolution 2178 was passed, one might have expected the Security Council and states to incorporate explicit and specific protections for humanitarian action, or to reaffirm expressly their commitment to humanitarian action in areas controlled by listed entities. This did not occur in Resolution 2178. One reason might be that those involved in crafting the resolution and those on the counterterrorism portfolios were not involved in the same discussions as those from the humanitarian or aid divisions. The Security Council did, however, expressly require that U.N. member states prevent and suppress the recruiting, organizing, transporting, or equipping of FTFs consistent with international humanitarian law (IHL). In doing so, the Council implicitly required states to discharge their FTF obligations in a manner that respects the various forms of humanitarian action protected by IHL. The Security Council did not, however, expressly require that states discharge each of the other key FTF obligations entailed in the resolution consistent with IHL. 


\title{
BRIEFING REPORT: 2 GOALS
}

\author{
1 \\ Provide a primer on the most salient issues at the intersection of counterterrorism \\ measures and humanitarian aid and assistance, with a focus on the ascendant FTF framing \\ <. 2 \\ Put forward, for critical feedback and assessment, a provisional methodology for \\ evaluating the following question: is it feasible to subject two key contemporary wartime \\ concerns - the fight against FTFs and supporting humanitarian aid and assistance for \\ civilians in terrorist-controlled territories-to meaningful empirical analysis?
}

After foregrounding the normative and operational frameworks, we note that FTF-related counterterrorism measures-following a long line of measures implementing increasingly robust anti-terrorism agendas - may have the capacity to adversely affect certain aspects of principled humanitarian action. Our research suggests, however, that more documentation from humanitarian organizations would be needed to firmly establish a systemic adverse impact of FTF-related counterterrorism measures on principled humanitarian action. We also note that the FTF framing by the Security Council may present a particularly strong opportunity for meaningful engagement between counterterrorism and humanitarian actors.

Defining "foreign terrorist fighters":

\begin{abstract}
"Nationals who travel or attempt to travel to a State other than their States of residence or nationality, and other individuals who travel or attempt to travel from their territories to a State other than their States of residence or nationality, for the purpose of the perpetration, planning, or preparation of, or participation in, terrorist acts, or the providing or receiving of terrorist training."
\end{abstract}

U.N. Security Council, Resolution 2178, para. 6(a)

In addition, we submit an analytical methodology aimed at ascertaining from an empirical perspective how (certain select) states have implemented the FTF-related obligations imposed by the Security Council in Resolution 2178 (2014) one year after its adoption. We also put forward a methodology aimed at ascertaining from an empirical perspective whether those same states are supporting —or, at least, not actively curtailing — humanitarian aid and assistance, especially in relation to conflicts involving FTFs and other terrorists. This section also offers provisional figures generated from the application of these methodologies to extant sources. In doing so, we developand invite critical feedback on-new ways to measure both of these areas of state practice. 


\section{State Selection}

Criteria

\footnotetext{
25

States selected

畻 P5

Permanent members of the Security Council, due to the importance of those states in developing binding counter-foreign terrorist fighter measures in particular and counterterrorism obligations in general
}

\section{Foreign Terrorist Fighters}

States with the highest reported numbers of foreign terrorist fighters per capita*

\section{(0] Humanitarian Donations to Iraq \& Syria}

Largest major state humanitarian donors, per capita, concerning two key conflicts involving foreign terrorist fighters (Iraq and Syria in 2015, as of July 2015)*

\section{x Border States}

States sharing borders with Syria and Iraq, since many foreign terrorist fighters may travel through those frontiers in order to reach the battlefield

*See Methodology section.

\section{Selected States}

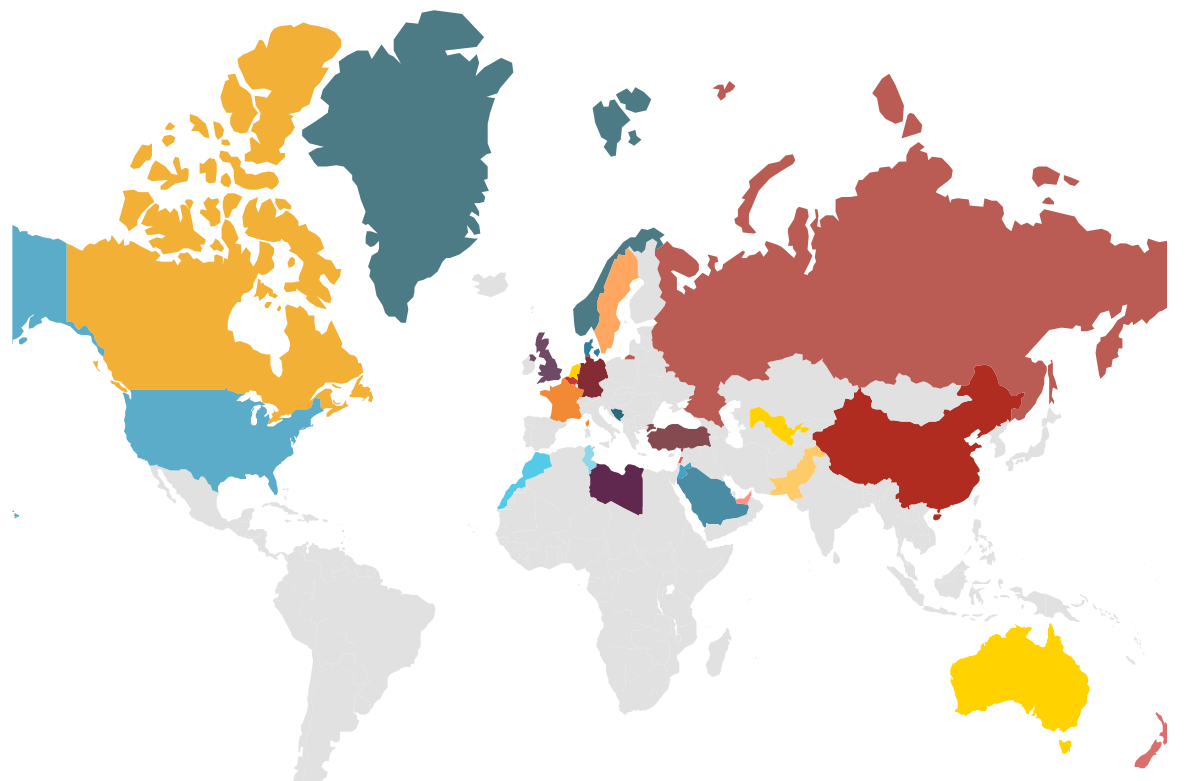




\section{Provisional Framework for Analyzing State Compliance with Key Foreign Terrorist Fighter Elements of Resolution 2178}

Provisional Indicators of State Compliance with Five Key Foreign Terrorist

Fighter Elements of Resolution 2178

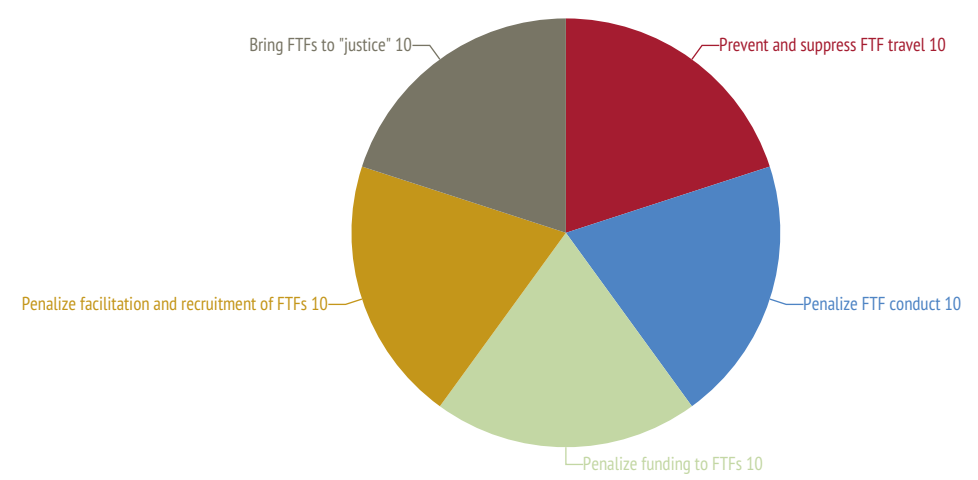

- Prevent and suppress FTF travel Penalize FTF conduct Penalize funding to FTFs Penalize facilitation and recruitment of FTFs

Bring FTFs to "justice"

10 potential points per subcategory

0 = lowest potential score per subcategory; 10 = highest potential score per subcategory; see Methodology section

Provisional Overall Compliance: Five Key Foreign Terrorist Fighter Elements of Resolution 2178

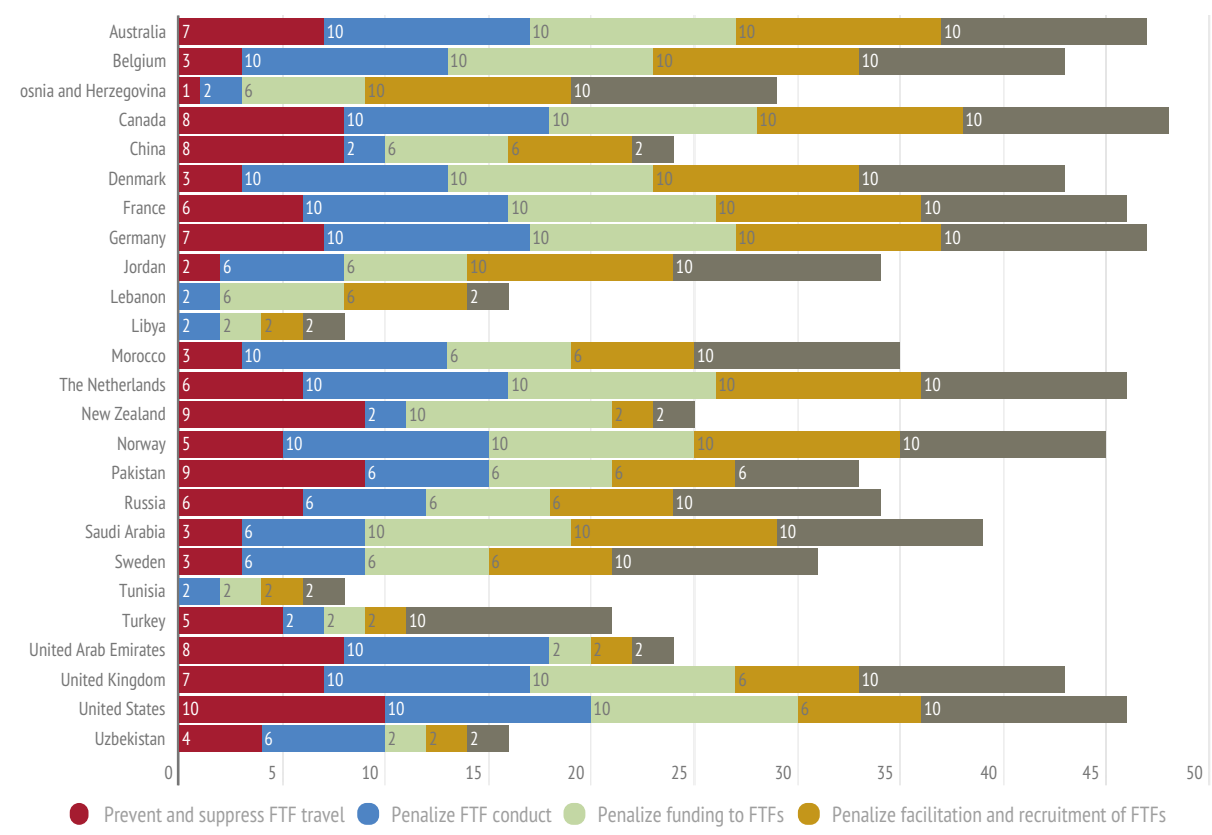

Bring FTFs to "justice" 


\section{Provisional Framework for Analyzing State Support of Principled Humanitarian Action in Counterterrorism Contexts}

Provisional Indicators of Support of Five Key Aspects of Principled Humanitarian Action in Counterterrorism Contexts

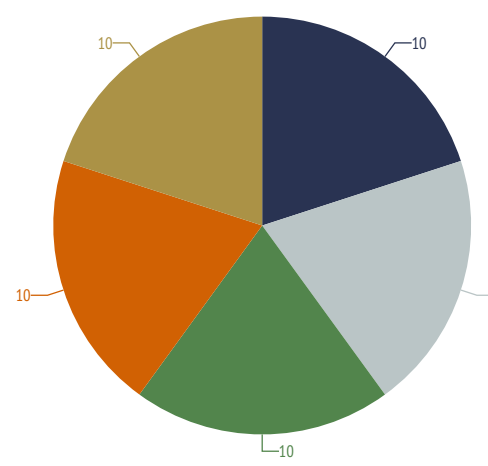

- Knowability of anti-terrorism lists Ease of navigating and efficiency of the regulatory system Explicit exemptions for principled humanitarian action

- No reported counterterrorism-based adverse legal proceedings nor reported counterterrorism-based "chilling effect" pertaining to principled humanitarian

- Financial supbort for humanitarian action in Iraa and Svria in 2015 (as of Julv 2015)

10 potential points per subcategory

Provisional Overall Support: 5 Key Aspects of Principled Humanitarian Action in Counterterrorism Contexts

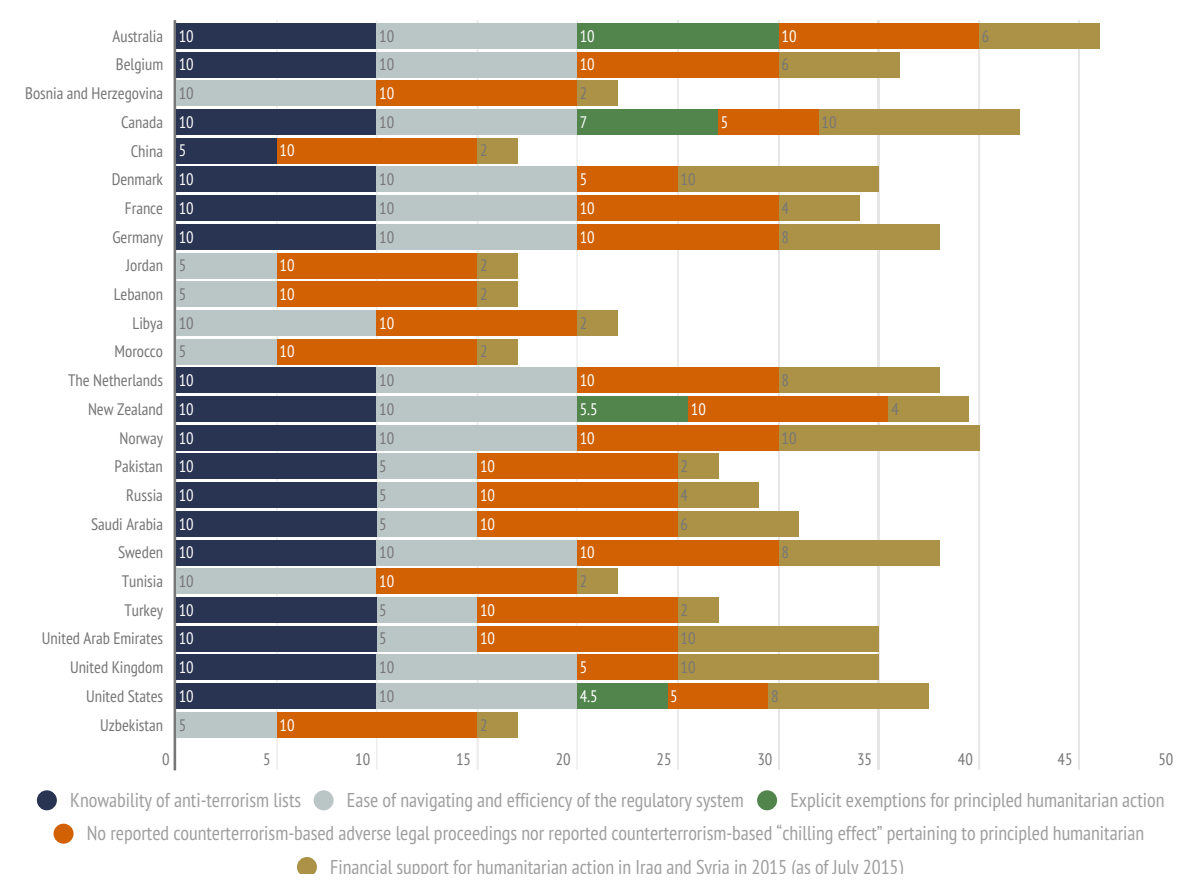




\section{OPPORTUNITIES AND CONCERNS FOR PRINCIPLED HUMANITARIAN ORGANIZATIONS}

Today, the overall political and operational environment for principled humanitarian action appears to be marked by increasingly aggressive counterterrorism responses. It may well be that donor states, states in the region, and states with comparatively greater numbers of FTFs experience the FTF threat as presenting a different order of national security concern than does terrorism more generally. Perhaps particularly in light of recent ISIS developments, refugee influxes into Europe, and al-Qaeda calling for lone-perpetrator attacks in the West, state responses appear to be tipping increasingly towards national security. These changing political realities should inform how humanitarian organizations understand the potential for additional changes to the regulatory environment. In particular, on the horizon there are six areas humanitarian actors should be particularly aware of and engaged with:

$\square$ Heightened administrative and programmatic burdens

Decreased freedom of movement of humanitarian personnel

Increased governmental scrutiny of national and regional staff

IIII Decreased access to financial services and funding channels

Elevated concerns regarding reputational harm

- Decreased autonomy of action with respect to engagement with all parties to armed conflict 


\section{RECOMMENDATIONS TO STRENGTHEN EVIDENCE-BASED DECISION-MAKING}

How could a better understanding of the relevant trends and trajectories-in state responses to the threats posed by foreign terrorist fighters, in state support of principled humanitarian action in counterterrorism contexts, and, especially, in the potential intersections between those areas of state practice-be established? Four areas may be particularly impactful to focus on in the current environment:

$\square$ Make assessments of state compliance with binding Security Council counterterrorism measures publicly available

Foster discussion and consensus on what it means to comply with IHL, IHRL, and IRL when discharging Security Council-imposed counterterrorism obligations, and make assessments of such compliance publicly available

\section{Evaluate whether to draft model exemptions from} counterterrorism obligations for principled
humanitarian action

Participate in efforts to document impact by building consensus around what counts as impact and then specifically identifying those impacts over time 


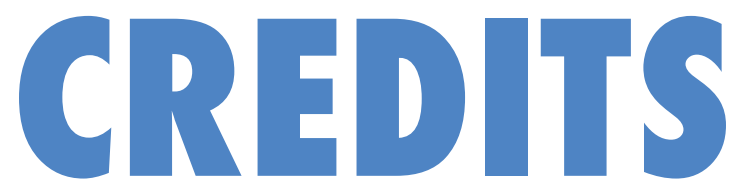

\begin{abstract}
ABOUT THE AUTHORS
Jessica Burniske, Dustin A. Lewis, and Naz K. Modirzadeh were the principal contributors to this Research Briefing. Ms. Burniske is an expert consultant for the Harvard Law School Program on International Law and Armed Conflict (HLS PILAC)'s Counterterrorism and Humanitarian Engagement Project (CHE Project). She performed the bulk of the underlying research for much of the qualitative analysis and most of the quantitative analysis. She also drafted the Appendix and portions of the report. Mr. Lewis, a Senior Researcher at the Program, provided legal and policy research and analysis; edited the report; created the charts, graphs, infographics, maps, and pictorials; and designed the print and online versions of the report. Ms. Modirzadeh, the Director of the Program who has also been designated a Lecturer on Law at Harvard Law School, conceptualized the initial framing of the report (with Mr. Lewis) and provided critical feedback on numerous drafts.
\end{abstract}

\title{
ACKNOWLEDGEMENTS AND DISCLAIMERS
}

This Briefing has been produced, in part, with the financial assistance of the Norwegian Ministry of Foreign Affairs (NFMA). The views expressed herein should not be taken, in any way, to reflect the official opinion of the NMFA. The Norwegian Refugee Council (NRC) facilitated this financial assistance through the NFMA. HLS PILAC/the CHE Project also receives generous support from the Swiss Federal Department of Foreign Affairs (FDFA). The views expressed herein should also not be taken, in any way, to reflect the official opinions of the Swiss FDFA nor NRC. The CHE Project is grateful for the support of the NMFA, NRC, and the Swiss FDFA. The research undertaken by the authors was completely independent. The views and opinions reflected in this report are those solely of the authors. And the authors alone are responsible for any errors.

The authors extend their thanks to Federica du Pasquier for research assistance; to Jennifer Allison, PILAC Liaison to the Harvard Law School Library (HLSL), and the staff of the HLSL for research support; to June Casey of the HLSL for open-access support; and to the Senior Law and Policy Working Group of the $\mathrm{CHE}$ Project for their insights and engagement around the issues discussed in this Briefing.

\section{LICENSE}

Creative Commons Attribution-NonCommercial-ShareAlike 4.0 International license (CC BY-NC-SA 4.0).

\section{SUGGESTED CITATION}

Jessica Burniske and Dustin A. Lewis, with Naz K. Modirzadeh, "Suppressing Foreign Terrorist Fighters and Supporting Humanitarian Action: A Provisional Framework for Analyzing State Practice," Research Briefing, Harvard Law School Program on International Law and Armed Conflict, October 2015.

\section{COVER PHOTO CREDIT}

Russ Allison Loar, "UN Security Council \& UN Security Guard," June 19, 2014, Flickr, License: Creative Commons Attribution-NonCommercial-NoDerivs 2.0 Generic (CC BY-NC-ND 2.0). 


\section{CHARTS}

- Subcategories: Provisional Indicators of State Compliance with Five Key Foreign Terrorist Fighter Elements of Resolution 2178, page 21

- Subcategories: Provisional Indicators of State Support of Five Key Aspects of Principled Humanitarian Action in Counterterrorism Contexts, page 30

\section{GRAPHS}

- Reported Foreign Fighters per Capita (per Million) for Selected States, page 22

- Provisional Indicators of Overall State Compliance with Five Key Foreign Terrorist Fighter Elements of Resolution 2178 Per Subcategory, page 27

- Provisional Indicators of Overall State Support of Five Key Aspects of Principled Humanitarian Action in Counterterrorism Contexts Per Subcategory, page 36

\section{INFOGRAPHICS}

- Report Goals, page iii

- State Section, page iv

- Provisional Framework for Analyzing State Compliance with Key Foreign Terrorist Fighter Elements of Resolution 2178, page v

- Provisional Framework for Analyzing State Support of Principled Humanitarian Action in Counterterrorism Contexts, page vi

- Opportunities and Concerns for Principled Humanitarian Organizations, page vii

- Recommendations to Strengthen Evidence-based Decision-making, page viii

- State Selection Criteria, page 15

\section{MAPS}

- Selected States, page 16

- Heat Map: Provisional Indicators of Overall State Compliance with Five Key Foreign Terrorist Fighter Elements of Resolution 2178 perTier, page 28

- Heat Map: Provisional Indicators of Overall State Support of Five Key Aspects of Principled Humanitarian Action in Counterterrorism Contexts per Tier, page 37

\section{PICTORIALS}

- Proportional Distribution of Reported Foreign Fighters by Nationality for 25 Selected States, pages $i$ and page 25

\section{WEB}

This report is available free of charge online at http://pilac.law.harvard.edu/ftf. 


\section{CONTENTS}

INTRODUCTION 1

Themes and Outline 3

2

INTERSECTIONS BETWEEN STATE RESPONSES

TO TERRORISM AND TO HUMANITARIAN EMERGENCIES IN ARMED CONFLICT

Simultaneously Converging and Diverging

Normative and Operational Frameworks

$\begin{array}{ll}\text { Security Council Responses to Terrorism } & 7\end{array}$

$\begin{array}{ll}\text { Supporting Principled Humanitarian Action } & 8\end{array}$

Intersections: State Responses to Terrorism and Supporting

Principled Humanitarian Action in Counterterrorism Contexts

3

PROVISIONAL QUANTITATIVE METHODOLOGY AND ANALYSIS

State Responses to Foreign Terrorist Fighters and

Support for Humanitarian Action in Counterterrorism Contexts $\quad 14$

Empirical Research Methodologies and Approaches

Selection of States

Research Caveats and Limitations of the Provisional Quantitative Findings 
Provisional Assessment and Allocation of Points

Provisional Indicators of State Compliance with Five

Key Foreign Terrorist Fighter Elements of Resolution 2178

Provisional Indicators of State Support of Five Key Aspects of

Principled Humanitarian Action in Counterterrorism Contexts

CONCLUSION

Opportunities and Concerns for Principled Humanitarian Organizations

Heightened administrative and programmatic burdens on humanitarian organizations in terms of their vetting and due diligence responsibilities

Decreased freedom of movement of humanitarian personnel

Increased governmental scrutiny of national and regional staff

Decreased access to financial services and funding channels

Elevated concerns regarding reputational harm

Decreased autonomy of action with respect to engagement with all parties to armed conflict

Recommendations to Strengthen

Evidence-based Decision-making

Evidence of and data on compliance with

Security Council counterterrorism measures

Monitoring compliance with relevant

(additional) fields of international law

Potential exemptions in counterterrorism measures for principled humanitarian action

Evidence and data related to potential counterterrorism impacts on humanitarian action 


\section{APPENDIX: RESEARCH BASES FOR PROVISIONAL QUANTITATIVE ALLOCATION OF POINTS PER STATE}

Australia

Belgium

Bosnia and Herzegovina

Canada

China

Denmark 60

France 62

Germany

Jordan 66

Lebanon

Libya 71

Morocco

The Netherlands

New Zealand

Norway

Pakistan

81

Russia

Saudi Arabia

Sweden

Tunisia

Turkey

United Arab Emirates

94

United Kingdom

96

United States

Uzbekistan 

Terrorism is nothing new; we have been facing it for years. But it has taken on another dimension; it is now looking to conquer territory, to set up States, to subjugate peoples. It is attacking civilian populations - women, children. It has new names; it is no longer called just Al-Qaida or Al-Qaida in the Islamic Maghreb, but Boko Haram or Daesh. Daesh is the most recent incarnation of this terrorist madness. It is a new phenomenon in the sense that it aims to conquer and also to recruit a growing number of our citizens, wherever they may be, into its ranks. It is attracting people, often young people, of all nationalities, and not just, as it is often said, those of Muslim origin - even though Islam has nothing to do with this fight.

— President Francois Hollande, Sept. 24, 2014 U.N. SCOR, 7272 mtg. at 6, U.N. Doc. S/PV.7272 



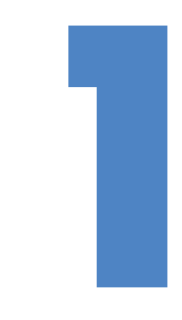

\section{INTRODUCTION}

In 2014, reports suggested that a surge of foreign jihadists were participating in armed conflicts in Syria, Iraq, and elsewhere. ${ }^{1}$ The United Nations Security Council responded by imposing an array of obligations on member states to counter the threat posed by "foreign terrorist fighters" (FTFs). In the intervening year, those states have taken a range of actions - though at various speeds and with varying levels of commitmentto implement the foreign terrorist fighter (FTF) obligations imposed by the Council. Meanwhile, the levels of humanitarian need in conflicts involving FTFs-already devastating-continue to swell.

Scholars, security experts, and policy analysts have assessed a number of issues relating to foreign fighters in general ${ }^{2}$ and to FTFs in particular. ${ }^{3}$ The humanitarian situation and the accompanying challenges in conflicts involving FTFs are relatively well-documented as well.

Building on that analysis, this paper has two goals. First, we aim to provide a primer on the most salient issues at the intersection of counterterrorism measures and humanitarian aid and assistance, with a focus on the ascendant FTF framing. Second, we seek to put forward, for critical feedback and assessment, a provisional methodology for evaluating the following question: is it feasible to subject two key contemporary wartime concerns - the fight against FTFs and supporting humanitarian aid and assistance for civilians in terrorist-controlled territories—to meaningful empirical analysis?

Of course, foreign fighters are not a new phenomenon in war. Since the advent of

1. See, e.g., Spencer Ackerman, Foreign Jihadists Flocking to Iraq and Syria on Unprecedented Scale - UN, The Guardian (Oct. 30, 2014).

2. Foreign Fighters Under International Law, Geneva Academy of International Humanitarian Law and Human Rights (Oct. 2014).

3. See, e.g., Daniel Byman \& Jeremy Shapiro, Be Afraid, Be a Little Afraid: The Threat of Terrorism from Western Foreign Fighters in Syria and Iraq, Brookings Institution, Policy Paper No. 34 (Nov. 2014). 


\title{
Proportional Distribution of Reported Foreign Fighters by Nationality for 25 Selected States*
}

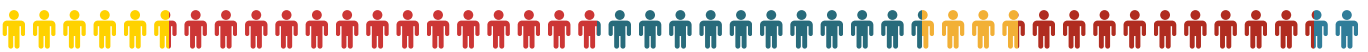

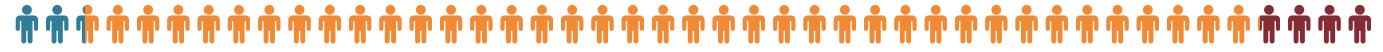

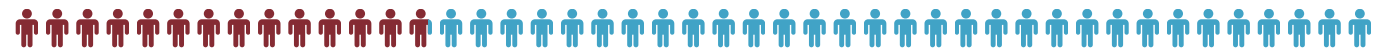

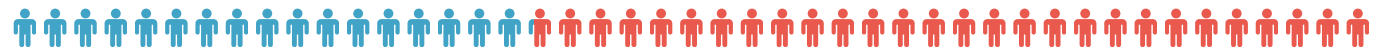

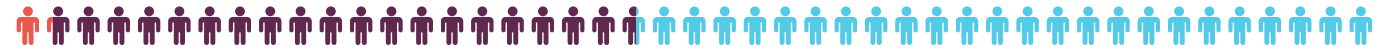

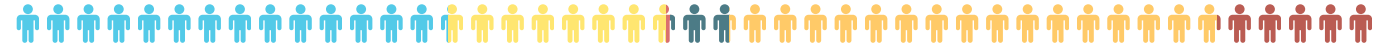

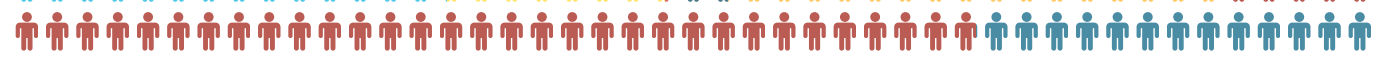

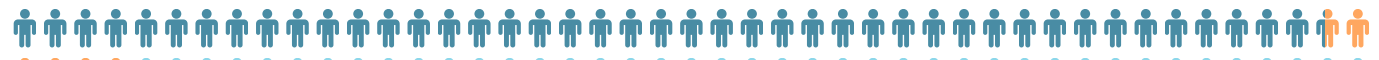

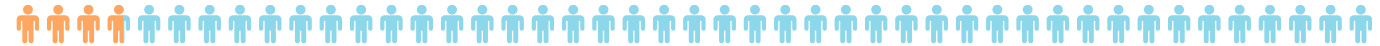

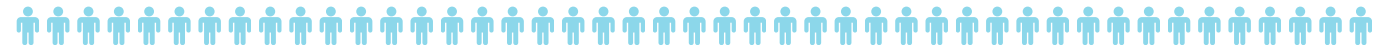

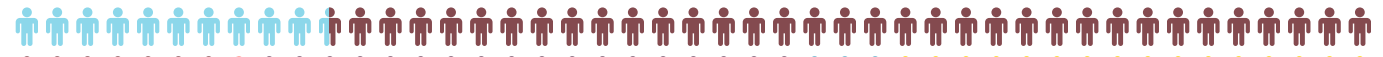

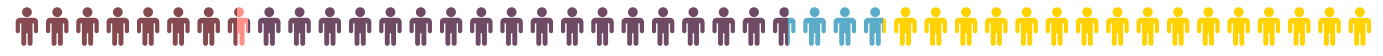

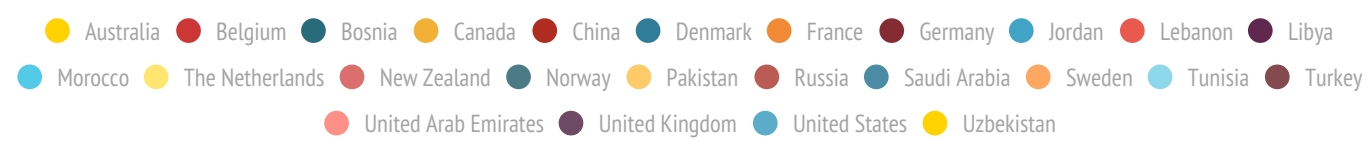

* Figures of foreign fighters came principally from International Centre for the Study of Radicalisation and Political Violence (January 26, 2015), available at http://icsr.info/2015/01/foreign-fighter-total-syriairaq-now-exceeds-20000-surpasses-afghanistan-conflict-1980s/, although for three states we had to find the numbers in other sources (e.g., news articles). Where an estimated range was given for a state, we added the range of estimates (the high and low figures) together and divided that combined figure in half to produce the estimate for that state.
\end{abstract}

the modern international system, foreigners and other non-nationals have participated in numerous armed conflicts. ${ }^{4}$ History books are replete with examples. Consider, for instance, the Texas Revolution (1835-36), the Spanish Civil War (1936-39), and certain recent conflicts in Afghanistan (1978-92). ${ }^{5}$

Yet with the growing power and influence of the Islamic State of Iraq and al-Sham (ISIS), states have become increasingly concerned about the rise of foreign fighters, and especially a sub-group of those fighters increasingly referred to as FTFs. The apparent trigger was the influx of foreign nationals into the armed conflict in Syria. As this flow of fighters continued, the international community sharpened its focus not only on foreign nationals traveling to support parties in conflict in an internal war but, more specifically, on Muslims or recent converts traveling to Syria to join jihadi organizations. This concern grew with the rise of al-Qaeda in Iraq and ISIS. ${ }^{6}$ On September 24, 2014, President Barack

4. See, e.g., David Malet, Foreign Fighters: Transnational Identity in Civil Conflicts 2013.

5. Interview by Robert Siegel with David Malet, University of Melbourne, NPR News (Oct. 21, 2014).

6. See, e.g., Nick Cumming-Bruce, Extremist Groups in Iraq Threaten Regional War, U.N. Panel Warns, N.Y. Times (June 17, 2014) http://www.nytimes.com/2014/06/18/world/middleeast/extremist-groups-in-iraq-threaten-regional-war-un- 
Obama convened a meeting of the Security Council that culminated in the unanimous adoption of Resolution 2178. Building on a long line of anti-terrorism measures, the resolution aims to stem the flow of FTFs to conflict zones. During this summit, heads of state overwhelmingly agreed that the passage of this resolution, and the recognition of the threat posed by FTFs, represented a shift in the nature and threat of terrorism, and that states would need to respond with increased regulation and enforcement. ${ }^{7}$

Meanwhile, many states continue to fund and otherwise throw their support behind life-saving humanitarian relief for civilians in armed conflicts around the worldincluding conflicts involving terrorists. Yet, in recent years, members of the humanitarian community have been increasingly aware of the real, perceived, and potential impacts of counterterrorism laws on humanitarian action. ${ }^{8}$ Part of their interest stems from the fact that certain counterterrorism laws may, intentionally or unintentionally, adversely affect principled humanitarian action, especially in regions where terrorist groups control territory (and thus access to civilians, too). The effects of these laws may be widespread-ranging from heightened due diligence requirements on humanitarian organizations to restrictions on travel, from greater government scrutiny of national and regional staff of humanitarian organizations to decreased access to financial services and funding. Counterterrorism measures may also in principle give rise to a "chilling effect" on humanitarian action. That is, humanitarian actors may choose not to undertake life-saving relief schemes that they otherwise would due to fears of violating counterterrorism laws and policies.

\section{Themes ANd OUtLine}

This report focuses on the concept of "foreign terrorist fighters" as it relates to U.N. Security Council practice and principled humanitarian action in situations of armed conflict involving terrorists. The following themes and inquiries form the broader backdrop for our analysis:

- The rise of the concept of and the legal and policy frameworks concerning FTFs;

- How those frameworks may affect existing counterterrorism laws, terrorist-listing mechanisms, and intelligence-sharing between governments;

panel-warns.html.

7. See, e.g., Remarks of President Francois Hollande, U.N. SCOR, 7272 mtg. at 6, U.N. Doc. S/PV.7272 (Sept. 24, 2014).

8. See, e.g., Sara Pantuliano et al., Counter-terrorism and Humanitarian Action: Tensions, Impact and Ways Forward, Humanitarian Policy Group, Policy Brief 43 (Oct. 2011). 
- How those frameworks may operate to broaden the monitoring and enforcement scope of key counterterrorism bodies, intelligence agencies, financial authorities, police, and courts;

- The real or potential impacts of those frameworks on the practical aspects of principled humanitarian action, for example in relation to travel, financial services, visas, and exemptions;

- Whether the FTF framing may operate so as to authorize increasingly robust offensive counterterrorism approaches; and

- Whether the rise of the concept of FTFs represents an opportunity to recalibrate the relationship between principled humanitarian action and counterterrorism efforts.

The terms "foreign fighters" and "foreign terrorist fighters" lack definitional consensus in international law. For our purposes, we use the following definitions:

Foreign fighter: An individual who leaves his or her country of origin or habitual residence to join a non-state armed group in an armed conflict abroad and who is primarily motivated by ideology, religion, and/or kinship. ${ }^{9}$

Foreign terrorist fighters (FTFs): As used by the United Nations Security Council: "Nationals who travel or attempt to travel to a State other than their States of residence or nationality, and other individuals who travel or attempt to travel from their territories to a State other than their States of residence or nationality, for the purpose of the perpetration, planning, or preparation of, or participation in, terrorist acts, or the providing or receiving of terrorist training."10

In Section 2, we frame the analysis by highlighting —at a 30,000-ft. view-potential trends and trajectories in the overlap between the counterterrorism and humanitarian spheres. Often thought to operate completely separate from one another, these spheres may come into contact, especially in armed conflicts involving terrorists. After foregrounding the normative and operational frameworks, we note that FTFrelated counterterrorism measures-following a long line of measures implementing increasingly robust anti-terrorism agendas-may have the capacity to adversely affect

9. Foreign Fighters Under International Law, Geneva Academy of International Humanitarian Law and Human Rights (Oct. 2014), at 6.

10. S.C. Res. 2178, para. 6(a), U.N. Doc. S/RES/2178 (Sept. 24, 2014). 
certain aspects of principled humanitarian action. ${ }^{11}$ Our research suggests, however, that more documentation from humanitarian organizations would be needed to firmly establish a systemic adverse impact of FTF-related counterterrorism measures on principled humanitarian action. We also note that the FTF framing by the Security Council may present a particularly strong opportunity for meaningful engagement between counterterrorism and humanitarian actors.

Next, in section 3, we submit an analytical methodology aimed at ascertaining from an empirical perspective how (certain select) states have implemented the FTF-related obligations imposed by the Security Council in Resolution 2178 (2014) one year after its adoption. We also put forward a methodology aimed at ascertaining from an empirical perspective whether those same states are supporting-or, at least, not actively curtailing-humanitarian aid and assistance, especially in relation to conflicts involving FTFs and other terrorists. This section also offers provisional figures generated from the application of these methodologies to extant sources. In doing so, we propose-and invite critical feedback on-new ways to measure both of these areas of state practice.

In the Conclusion, we highlight areas that merit further attention from counterterrorism and humanitarian actors. We also observe how states, U.N. bodies, and humanitarian organizations can provide a better basis on which to formulate research and analysis - and thus, ultimately, policy-with respect to FTF measures and to principled humanitarian action in terrorist-controlled territories.

11. For purposes of this report, by "principled humanitarian action," we mean humanitarian action defined by the principles of humanity, independence, neutrality, and impartiality. Humanity means that human suffering must be addressed wherever it is found. Neutrality means that humanitarian actors must not take sides in hostilities. Impartiality means that humanitarian action must be carried out on the basis of need alone, and making no distinctions on the basis of characteristics such as nationality, race, and gender. Independence means that humanitarian action must be autonomous from the objectives of any actor with regard to the areas where humanitarian action is being implemented. See, e.g., UN OCHA on Message: Humanitarian Principles, https:// docs.unocha.org/sites/dms/Documents/OOM-humanitarianprinciples_eng_June12.pdf. 


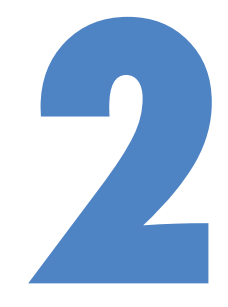

\section{INTERSECTIONS BETWEEN STATE RESPONSES TO TERRORISM AND TO HUMANITARIAN EMERGENCIES IN ARMED CONFLICT}

This section aims to provide a 30,000-ft. view of the key areas of convergence and, especially, divergence between state responses to the threat posed by foreign terrorist fighters, on one hand, and state support of principled humanitarian action in counterterrorism contexts, on the other.

\section{Simultaneously Converging and Diverging Normative and Operational Frameworks}

Since the late 1990s, states and international bodies have increasingly adopted laws and policies to respond to threats posed by al-Qaeda and other non-state actors designated as terrorists. At the same time, humanitarian crises where designated terrorists control territory and access to civilians have demonstrated the continued need for effective lifesaving relief. ${ }^{1}$ While counterterrorism policies and humanitarian action may, from some

1. See, e.g., Mohammed Hussein, Humanitarian Crisis of Immense Magnitude Looms in Yemen, Al-Jazeera (April $25,2015)$. 
perspectives, share several goals in principle, they intersect in ways that may also result in sharp tensions or even in direct conflict.

\section{Security Council Responses to Terrorism}

Terrorism has been a matter of international concern at least since the 1930 s. $^{2}$ Since the 1960s, States have agreed to numerous anti-terrorism conventions, at the international and regional levels. And, more recently, courts have addressed customary international law concerning transnational terrorism. But the last decade and a half has witnessed a surge in counterterrorism policies and programming at the international level. The U.N. Security Council is one of the key drivers of these initiatives. In the years immediately prior to, but especially in the aftermath of, the attacks of September 11, 2001, the Council took action to protect states and to deter and punish terrorist acts.

Two clusters of Security Council decisions, in particular, require states to address the threat to international peace and security posed by terrorism. The first cluster originated in 1999 in Security Council Resolution 1267. ${ }^{3}$ That line of resolutions requires states to (among other things) take steps to impose a travel ban, an asset freeze, and an arms embargo on al-Qaeda and associated individuals and groups. In the second, sometimes overlapping, cluster of decisions, which originated in Resolution 1368 in 2001, the Security Council "legislated" a global net of counterterrorism interdiction. ${ }^{4}$ In general, this second cluster requires member states to develop laws and measures to improve their ability to prevent terrorist acts. For instance, these resolutions require member states to:

- Criminalize certain acts associated with terrorism;

- Freeze funds of individuals involved in terrorist acts;

- Cooperate with other states to share information that could prevent terrorist acts from occurring; and

- Prescribe criminal penalties for committing terrorist acts. ${ }^{5}$

Following the buildup of these resolutions, in 2014 the Security Council homed in on a newly framed threat: foreign terrorist fighters.

2. This paragraph and the subsequent paragraph are based on the analysis and citations drawn from Dustin A. Lewis, Naz K. Modirzadeh, and Gabriella Blum, "Medical Care in Armed Conflict: International Humanitarian Law and State Responses to Terrorism," Legal Briefing, Harvard Law School Program on International Law and Armed Conflict, September 2015, pp. 100-2, available at: http://pilac.law.harvard.edu/mcac.

3. S.C. Res. 1267, U.N. Doc. S/RES/1267 (Oct. 15, 1999).

4. See, e.g., Paul C. Szasz, "The Security Council Starts Legislating," 96 AJIL 901 (2002).

5. S.C. Res. 1368, U.N. Doc. S/RES/1368 (Sept. 12, 2001). 
What brought about the focus on foreign terrorist fighters last year? According to President Obama, the "unprecedented flow of foreign fighters in recent years to and from conflict zones" ${ }^{\prime 6}$ provided the impetus for Resolution 2178 . Passed pursuant to the Council's Chapter VII powers under the U.N. Charter, member states are obliged to carry out the decisions entailed in the resolution. ${ }^{7}$ In general, the resolution requires states to implement new, or enforce existing, laws and policies to suppress the flow of FTFs into areas like Syria and Iraq. At the associated High-Level Summit, state after state aligned themselves and their constituencies with the goals of the resolution. ${ }^{8}$

By design, state responses to the threat posed by FTFs are multi-dimensional. U.N. Secretary General Ban Ki-Moon has noted that the "dynamic evolution of terrorist threats" requires a "creative and comprehensive approach [...] to stem the flow of foreign fighters [...]." ${ }^{9}$ Guided by the notion that "good governance kills terrorism,"10 the resolution requires member states to place restrictions on the travel of FTFs and to increase efforts to prevent and deter individuals from becoming FTFs. The resolution also emphasizes increased cooperation between states to share information and to build capacity to address the issue of FTFs, and to prosecute and to "bring to justice" individuals that support, fund, plan, or perpetrate terrorist acts. ${ }^{11}$

Despite being passed only a year ago, Resolution 2178 already appears to be on a trajectory to have an enduring impact. The resolution requires member states to implement measures that reinforce-as well as go beyond-the obligations in earlier counterterrorism decisions.

Looming in the background of Resolution 2178 is the concern that people faraway from conflict zones may be inspired by the efforts of FTFs to carry out attacks in their home countries. $^{12}$ In short, the underlying impetus for Resolution 2178 is the notion that FTFs pose a threat to everyone, everywhere. And, indeed, the High-Level Summit in 2014 made clear that states agree that FTFs pose a pressing threat to international peace and security.

\section{Supporting Principled Humanitarian Action}

More than half a century before the initial rise of terrorism as a matter of international concern, states agreed-in international law-to inject protections for humanitarian

6. Remarks of President Barack Obama, U.N. SCOR, 7272 mtg. at 3, U.N. Doc. S/PV.7272 (Sept. 24, 2014).

7. U.N. Charter, arts. 25, 39, and 48.

8. See U.N. SCOR, 7272 mtg., U.N. Doc. S/PV.7272 (Sept. 24, 2014).

9. U.N. SCOR, 7272 mtg. at 2-3, U.N. Doc. S/PV.7272 (Sept. 24, 2014).

10. Id. at 3 .

11. S.C. Res. 2178, paras. 2, 6, 8 and 11, U.N. Doc. S/RES/2178 (Sept. 24, 2014).

12. See Remarks of President Barack Obama, U.N. SCOR, 7272 mtg. at 4, U.N. Doc. S/PV.7272 (Sept. 24, 2014). 
measures into the cruelty of war. ${ }^{13}$ The initial manifestation of those efforts was the in legal protection for impartial wartime medical care. As early as 1864, states agreed in an international humanitarian law (IHL) ${ }^{14}$ convention to treat wounded and sick combatants irrespective of nationality-and even to allow the civilian population to provide such care.

In the intervening 150-plus years, states have expanded the scope of legally enshrined humanitarian activities in armed conflict. Today, many states have also put support of principled humanitarian action - through normative commitments, financial contributions, and other channels - at the forefront of their foreign policy platforms. States also regularly endorse the importance of ensuring the safety and effectiveness of relief actions.

Discerning the technical scope of IHL humanitarian-assistance provisions applicable to a particular conflict may be quite complicated. It typically requires an assessment of applicable treaty provisions and rules of customary IHL. But the upshot is that states have agreed to numerous protections for principled humanitarian action in situations of armed conflict. ${ }^{15}$ Perhaps most fundamentally, under IHL a genuine offer of impartial humanitarian assistance-by another state or by a principled humanitarian organization-may not be considered an unfriendly act. ${ }^{16}$

Of course, as with so many other elements of IHL, states devised the specific protections concerning relief schemes by balancing humanitarian concerns alongside considerations of military necessity. ${ }^{17}$ For instance, some IHL treaties stipulate that humanitarian actors

13. This paragraph is based on the analysis and citations drawn from Dustin A. Lewis, Naz K. Modirzadeh, and Gabriella Blum, "Medical Care in Armed Conflict: International Humanitarian Law and State Responses to Terrorism," Legal Briefing, Harvard Law School Program on International Law and Armed Conflict, September 2015, pp. 38-56, available at: http://pilac.law.harvard.edu/mcac.

14. The International Committee of the Red Cross succinctly defines international humanitarian law (IHL) as "[a] set of international legal rules that seek to limit the effects of armed conflict. It protects people who are not or are no longer participating in hostilities and restricts the means and methods of warfare." International Committee of the Red Cross, https://www.icrc.org/en/war-and-law. IHL applies only in relation to situations of armed conflict as defined in international law.

15. See, e.g., Heike Spieker, "The Right to Give and Receive Humanitarian Assistance," in International Law and Humanitarian Assistance 7-31 (H.-J. Heintze and A. Zwitter eds., 2011); Felix Schwendimann, "The legal framework of humanitarian access in armed conflict," 93 IRRC 884 (2011) 1007-1008.

16. See, e.g., article 70(1) Protocol Additional to the Geneva Conventions of 12 August 1949, and Relating to the Protection of Victims of International Armed Conflicts, June 8, 1977, 1125 U.N.T.S. 3 (AP I); Emanuela-Chiara Gillard, "The law regulating cross-border relief operations," 95 IRRC 890 (2013) 364.

17. On the more general point, see, e.g., Michael N. Schmitt, "Military Necessity and Humanity in International Humanitarian Law: Preserving the Delicate Balance," 50 VIIL 4 (2010). On the more specific point concerning 
must comport with certain principles_such as impartiality-in order to benefit from these particular protections. ${ }^{18}$ (In general, under IHL in situations of armed conflict humanitarian relief personnel are accorded the status of civilians, so long as they do not forfeit that status by, for instance, taking a direct part in hostilities.)

Against the development of this normative background, today, as practical matter, four principles-humanity, impartiality, neutrality, and independence-often define what is considered to constitute "principled humanitarian action."19 These principles aim foremost to help enable humanitarian aid and assistance to reach intended beneficiaries. Those beneficiaries are principally the members of the civilian population in need of assistance as well as those not, or no longer, participating in hostilities. In theory, though not always in practice, these principles serve to facilitate the work of and protect humanitarian actors.

Despite adherence to these principles, however, certain conditions may adversely affect the ability of humanitarian organizations to successfully negotiate access to, to provide assistance to, and to help protect intended beneficiaries. For instance, humanitarian organizations may be perceived as politically motivated or representing foreign interests, which may cause states or non-state armed groups in control of territory to deny access to those organizations. Further, counterterrorism laws may impose additional obligations on humanitarian actors, such as relatively more onerous due-diligence requirements including vetting of local partners.

\section{Intersections: State Responses to Terrorism and Supporting Principled Humanitarian Action in Counterterrorism Contexts}

Seen in one light, counterterrorism policies and principled humanitarian action may be thought to share several goals. In principle, they both aim, for instance, to protect civilians

conditions of humanitarian access and assistance, see, e.g., Felix Schwendimann, "The legal framework of humanitarian access in armed conflict," 93 IRRC 884 (2011) 997-1002.

18. See, e.g., articles 3(2) Convention (I) for the Amelioration of the Condition of the Wounded and Sick in Armed Forces in the Field, August 12, 1949, 75 U.N.T.S. 31 (GC I), 3(2) Convention (II) for the Amelioration of the Condition of Wounded, Sick and Shipwrecked Members of Armed Forces at Sea, August 12, 1949, 75 U.N.T.S. 85 (GC II), 3(2) Convention (III) Relative to the Treatment of Prisoners of War, August 12, 1949, 75 U.N.T.S. 135 (GC III), 3(2) Convention (IV) Relative to the Protection of Civilian Persons in Time of War, August 12, 1949, 75 U.N.T.S. 287 (GC IV), 69(2) and 71 AP I, and 18(2) Protocol Additional to the Geneva Conventions of 12 August 1949, and Relating to the Protection of Victims of Non-international Armed Conflicts, June 8, 1977, 1125 U.N.T.S. 609 (AP II).

19. See, e.g., UN OCHA on Message: Humanitarian Principles, https://docs.unocha.org/sites/dms/Documents/ OOM-humanitarianprinciples_eng_June12.pdf. 
from the often-devastating effects of war and to ensure that life-saving assistance reaches intended beneficiaries.

Tensions have emerged, however, between state approaches to these two areas. These tensions are often sharpest for humanitarian actors operating in territories controlled by terrorist groups. In recent years, designated terrorists have controlled territory (and thus access to civilians) in armed conflicts in, for instance, Afghanistan, Gaza, Iraq, Libya, Mali, Nepal, Pakistan, the Philippines, Somalia, Syria, and Yemen.

Some states' domestic counterterrorism legislation casts humanitarian aid and assistance-including the steps preparatory to providing such assistance, such as paying fees to de facto authorities designated as terrorists-as impermissible forms of support to the enemy. ${ }^{20}$ Furthermore, it is relatively rare for states to expressly exempt from counterterrorism laws principled humanitarian action. And where such exemptions do exist, they may be quite limited. In certain contexts, states may be concerned that humanitarian activities could serve as conduits for potential terrorist activity, through acts like the provision of funds or supplies. Similarly, such humanitarian organizations may be perceived-despite certain nascent evidence to the contrary ${ }^{21}$ —as having weak internal mechanisms to assess and respond to risks posed by operations in volatile areas where terrorist groups remain active. The work of the Financial Action Task Force and other intergovernmental bodies may have exacerbated these perceptions, particularly in identifying the non-profit sector as especially vulnerable to terrorist abuse.22

These concerns may make donors to humanitarian organizations, including states and intergovernmental organizations, reticent to provide funds to humanitarian organizations operating in areas where terrorist groups control territory. That reticence can thwart the efforts of humanitarian organizations to operate in high-risk environments, even though these environments often contain civilians that desperately need assistance.

To develop more knowledge about and to raise awareness of the tensions between

20. For instance, the United States criminalizes material support for terrorism, to include a broad range of activities and supplies, such as funding, lodging, "expert advice or assistance," and personnel, but exempts only the provision of medicine and religious materials. See 18 U.S.C. 2339A and B.

21. See Counterterrorism and Humanitarian Engagement Project, "An Analysis of Contemporary Anti-Diversion Policies and Practices of Humanitarian Organizations," Research and Policy Report, Harvard Law School, May 2014.

22. Financial Action Task Force, Best Practice on Combating the Abuse of Non-Profit Organizations (Recommendation 8), http:// www.fatf-gafi.org/topics/fatfrecommendations/documents/bpp-combating-abuse-npo.html. But see Financial Action Task Force, Combating the Abuse of Non-Profit Organizations (Recommendation 8) (June 2015) 4-7 (recognizing the "vital importance" of nonprofit organizations "in providing charitable services throughout the world" and qualifying the recommendation by noting that not all organizations are "high-risk"). 
state responses to terrorism and principled humanitarian action, donors have funded major studies and events, as well as various forms of dialogue-both between individual donors and humanitarian actors and by bringing together multiple donors and humanitarian actors. ${ }^{23}$ Donors have also supported a number of related key initiatives (including our own: the Counterterrorism and Humanitarian Engagement Project at Harvard Law School) that further attempt to bridge the humanitarian and security spheres in these areas.

A number of common themes emerge from existing research. Counterterrorism measures may contribute to heightened due diligence requirements on humanitarian organizations as well as additional restrictions on their travel. Greater governmental scrutiny of national and regional staff of humanitarian organizations may arise out of counterterrorism concerns, too. Anti-terrorism policies may contribute to decreased access to financial services and funding for humanitarian organizations, including as a result of financial institutions' de-risking due to counterterrorism-related concerns. Without sufficient legal protections built into counterterrorism measures, humanitarian organizations may choose to cease operations in areas where civilian populations need assistance. This reportedly occurred, for example, in the humanitarian community's response to the famine in Somalia and the complications posed by the dominance of al-Shabaab, a listed terrorist organization that controlled large amounts of territory in Somalia. ${ }^{24}$

In 2011, amid rising concern, the International Committee of the Red Cross (ICRC) pinpointed an array of fundamental challenges that state responses to terrorism may pose to principled humanitarian action:

The prohibition in criminal legislation of unqualified acts of 'material support', 'services' and 'assistance to' or 'association with' terrorist organizations could thus in practice result in the criminalization of the core activities of humanitarian organizations and their personnel aimed at meeting the needs of victims of armed conflicts and situations of violence below that

23. See, e.g., Kate Mackintosh \& Patrick Duplat, Study of the Impact of Donor Counter-Terrorism Measures on Principled Humanitarian Action, OCHA and the NRC (July 2013); Counterterrorism and Humanitarian Engagement Project, "An Analysis of Contemporary Anti-Diversion Policies and Practices of Humanitarian Organizations," Research and Policy Report, Harvard Law School, May 2014; Counterterrorism and Humanitarian Engagement Project, "An Analysis of Contemporary Counterterrorism-related Clauses in Humanitarian Grant and Partnership Agreement Contracts," Research and Policy Report, Harvard Law School, May 2014.

24. See, e.g., Laura Hammond \& Hannah Vaughan-Lee, Humanitarian Space in Somalia: A Scare Commodity, Humanitarian Policy Group Working Paper (April 2012). 
threshold. These could include: visits and material assistance to detainees suspected of or condemned for being members of a terrorist organization; facilitation of family visits to such detainees; first aid training; war surgery seminars; IHL dissemination to members of armed opposition groups included in terrorist lists; assistance to provide for the basic needs of the civilian population in areas controlled by armed groups associated with terrorism; and large-scale assistance activities to internally displaced persons, where individuals associated with terrorism may be among the beneficiaries. ${ }^{25}$

These and other concerns led the ICRC to call on states to (among other things) "exclude from the ambit of such offences activities that are exclusively humanitarian and impartial in character and are conducted without adverse distinction" when crafting legislation creating criminal offenses of "material support," "services" and "assistance" to or "association" with persons or entities involved in terrorism. ${ }^{26}$

Given the awareness of the risks of counterterrorism laws and regulations to humanitarian action by the time Resolution 2178 was passed, one might have expected the Security Council and states to incorporate explicit and specific protections for humanitarian action, or to reaffirm expressly their commitment to humanitarian action in areas controlled by listed entities. This did not occur in Resolution 2178 . One reason might be that those involved in crafting the resolution and those on the counterterrorism portfolios were not involved in the same discussions as those from the humanitarian or aid divisions. The Security Council did, however, expressly require that U.N. member states prevent and suppress the recruiting, organizing, transporting, or equipping of FTFs consistent with IHL. ${ }^{27}$ In doing so, the Council implicitly required states to discharge their FTF obligations in a manner that respects the various forms of humanitarian action protected by IHL. The Security Council did not, however, expressly require that states discharge each of the other key FTF obligations entailed in the resolution consistent with IHL.

25. International Committee of the Red Cross, International Humanitarian Law and the challenges of contemporary armed conflicts, doc. 31IC/11/5.1.2, October 2011, Geneva, p. 52 [emphasis added].

26. Id. at 53.

27. S.C. Res. 2178, para. 5, U.N. Doc. S/RES/2178 (Sept. 24, 2014). 


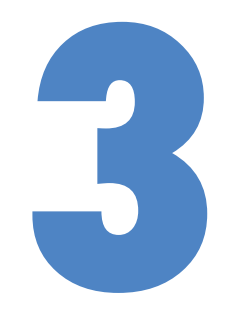

\section{PROVISIONAL QUANTITATIVE METHODOLOGY AND ANALYSIS}

\section{State Responses to Foreign Terrorist Fighters and Support for Humanitarian Action in Counterterrorism Contexts}

Most assessments of compliance with Security Council obligations are qualitative in nature. The same goes for the extent to which states support principled humanitarian action. That makes sense on both accounts, as neither of these areas of concern may appear, at first glance, to be particularly susceptible to empirical analysis.

Yet we were compelled to combine quantitative and qualitative assessments of subtopics within these areas for two reasons. Most importantly, we wanted to see if, by combining these forms of assessment, we could learn and explain something new and meaningful about these two areas of state practice-on their own and in combination. We also wanted to reach a broader audience. Visualizations of data-in charts and maps, for instance-may help catalyze interest in these areas among those for whom a more traditional qualitative analysis may be less interesting or less accessible. As both researchers and analysts, we hoped to draw connections between these quantitative and qualitative assessments that may prove to be informative and innovative.

\section{Empirical Research Methodologies and Approaches}

In this sub-section, we summarize how we undertook our empirical research; what types of data and other sources we used; and important caveats to our findings. Through 
this line of research, we have attempted to bring new and impactful ways of thinking, researching, evaluating, and disseminating information and analysis involving the ways states give effect to their counterterrorism obligations and how states support humanitarian action in counterterrorism contexts. As this is a first attempt on our part to think through some of the methodologies and analytical implications, we invite critical feedback. We emphasize that, due to the caveats listed later in the section, all of the results of this section should be considered provisional.

\section{Selection of States}

Due to time and resource constraints, we could not review every U.N. member state's compliance with Resolution 2178. Nor could we examine the extent to which every such state supports principled humanitarian action in counterterrorism contexts. Instead, we narrowed the list to a manageable number by applying a few filters to obtain a crosssection of especially relevant states (see "State Selection Criteria" graphic, below).

\section{State Selection Criteria}

\section{5}

States selected

圈 P5

Permanent members of the Security Council, due to the importance of those states in developing binding counter-foreign terrorist fighter measures in particular and counterterrorism obligations in general

\section{₹ Foreign Terrorist Fighters}

States with the highest reported numbers of foreign terrorist fighters per capita*

\section{(1.) Humanitarian Donations to Iraq \& Syria}

Largest major state humanitarian donors, per capita, concerning two key conflicts involving foreign terrorist fighters (Iraq and Syria in 2015, as of July 2015)*

\section{Border States}

States sharing borders with Syria and Iraq, since many foreign terrorist fighters may travel through those frontiers in order to reach the battlefield 


\section{Selected States}

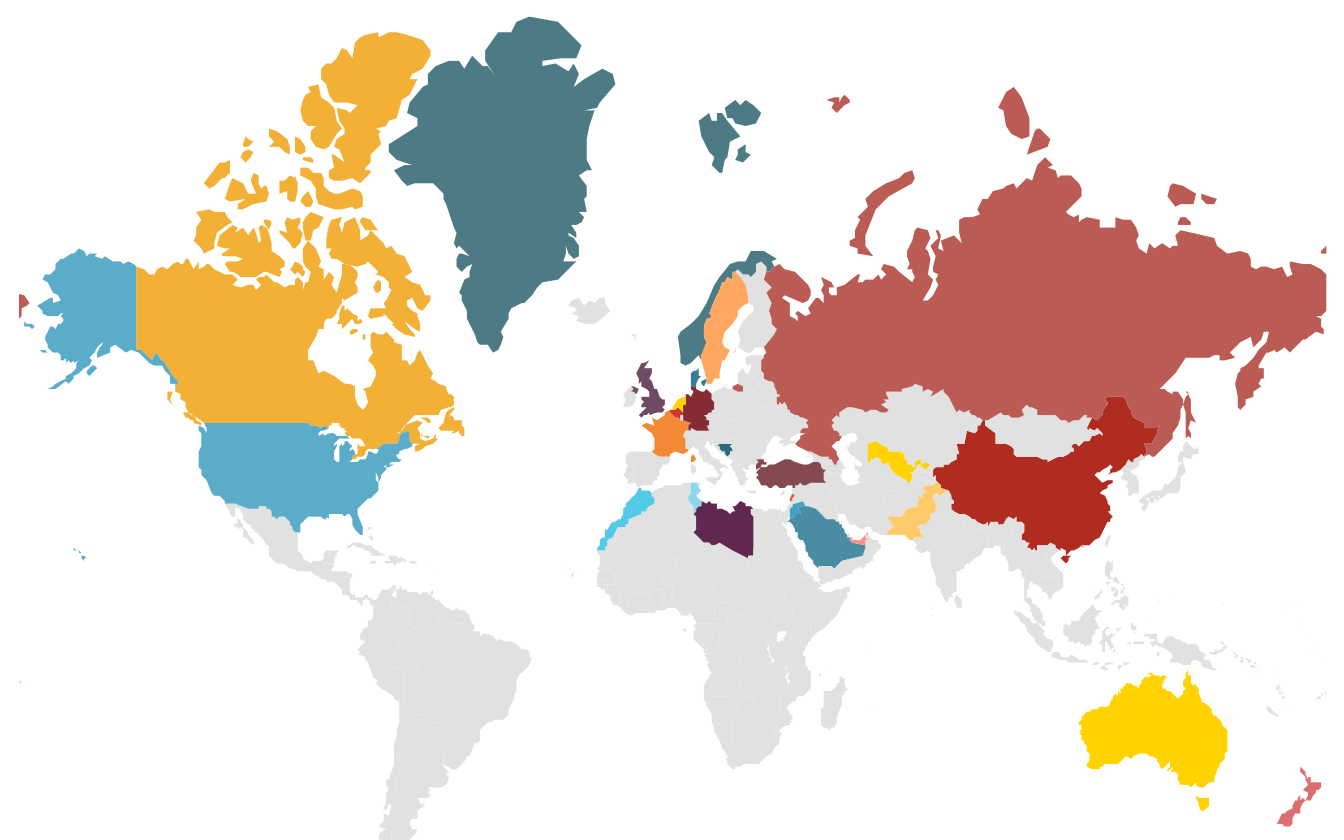

Based on these considerations, we ultimately selected twenty-five states for initial review: Australia, Belgium, Bosnia and Herzegovina, Canada, China, Denmark, France, Germany, Jordan, Lebanon, Libya, Morocco, the Netherlands, New Zealand, Norway, Pakistan, Russia, Saudi Arabia, Sweden, Tunisia, Turkey, the United Arab Emirates, the United Kingdom, the United States, and Uzbekistan (see "Selected States" map, above).

\section{Research Caveats and Limitations of the Provisional Quantitative Findings}

To effectively identify and use quantitative metrics in both of these areas of concern, we had to try to overcome numerous methodical and analytical hurdles. Our provisional analysis should be read with the following six sets of limitations and other considerations in mind.

\section{Translating Security Council-imposed FTF obligations into quantitative} figures. We had to decide how to translate the relevant binding Security Council obligations into quantifiable figures. ${ }^{1}$ This proved quite challenging. As an initial

1. Other researchers have quantitatively assessed, for instance, compliance with Security Council obligations in the context of ending civil wars. Christoph Mikulaschek and Chris Perry, "When Do Civil-War Parties Heed the UN? Findings from the IPI Security Council Compliance Database," New York: International Peace Institute, December 2013. 
matter, interpreting Security Council resolutions-including the relative "bindingness" of the obligations imposed in decisions - can be a highly technical exercise. ${ }^{2}$ More specifically, for its part Resolution 2178 is one of many in two long lines of related Security Council decisions concerning terrorism. We therefore had to choose which of the obligations imposed in Resolution 2178 were the most salient ones for our analysis; how to combine similar types of obligations into overarching categories; and which obligations in Resolution 2178 to leave out. Lastly, we had a bias toward identifying ways that states comply with Resolution 2178 that are relatively more susceptible to empirical metrics. There are at least two downsides to these approaches: (i) our analysis does not assess compliance with Resolution 2178 in a comprehensive fashion; and (ii) our analysis necessarily turns in part on an allocation of points based on our, as researchers, relative assessment of the importance of the underlying obligation and how those obligations may be usefully grouped together.

\section{Translating state support of principled humanitarian action in} counterterrorism contexts into quantitative figures. We went through the same process to decide how to translate ways that states support principled humanitarian action in counterterrorism contexts-especially concerning Iraq and Syria-into quantifiable figures. This, too, proved very difficult. As a threshold issue, there are no comprehensive, agreed-upon metrics to discern the extent to which states support principled humanitarian action in counterterrorism contexts in general-let alone concerning how states do so while countering FTF threats in particular. Thus we needed to pick and choose among

2. Resolutions passed under the United Nations' Chapter VII powers are generally considered to be legally obligatory on all member states. In addition, the presence of certain language, such as "decides," often signals a legal obligation, but the use of other language, such as "calls upon," may be less clear. Security Council Report, Special Research Report No. 1: Security Council Action Under Chapter VII: Myths and Realities, June 23, 2008, available at http:// www.securitycouncilreport.org/special-research-report/lookup-c-glKWLeMTIsG-b-4202671.php. As President Obama noted in his remarks following the passage of Resolution 2178, however,

[The resolution] is legally binding. It establishes new obligations that states must meet. Specifically, nations are required to prevent and suppress the recruiting, organizing, transporting, or equipping of foreign terrorist fighters as well as the financing of their travel or activities. Nations must prevent the movement of terrorists or terrorist groups through their territory and ensure that domestic laws allow for the prosecution of those who attempt to do so.

Remarks of President Barack Obama, U.N. SCOR, 7272 mtg. at 4, U.N. Doc. S/PV.7272 (Sept. 24, 2014). We used the work of United Nations scholars and past U.N. Security Council counterterrorism resolutions to help determine which of Resolution 2178's provisions constituted legally binding obligations on member states. See, e.g., Michael C. Wood, The Interpretation of Security Council Resolutions, 2 Max Planck Yearbook of United Nations Law, 73-95 (1998). 
existing metrics (where available) and come up with our own (where they did not exist). And, as in the area of compliance with Resolution 2178, we also had a bias toward identifying ways that states support principled humanitarian action in counterterrorism contexts that are relatively more susceptible to quantifiable metrics. As noted with the assessment of compliance with Resolution 2178, two downsides of this approach are (i) that our analysis does not assess the relevant support of principled humanitarian action in a comprehensive fashion, and (ii) that our analysis necessarily turns in part on an allocation of points based on our, as researchers, relative assessment of the underlying issues pertaining to principled humanitarian action.

3. Designing a set of quantitative measurement scales. We had to decide which type of measurement would be most useful to discern something meaningful about each area of concern. To give our quantitative analysis a basic structure, we settled on a 50-point scale for each of the two segments. That is, each area of concern-(i) compliance with key FTF-related aspects of Resolution 2178 and (ii) key areas of support of principled humanitarian action in counterterrorism contexts-was allocated its own 50-point scale.

4. Dividing the relevant areas of state practice into elements that are susceptible to quantitative analysis. We divided up the two main areas of concern in such a way that we could effectively conduct research into the underlying issues. Tracking the parity in the partition of the 50-point scales per main area of concern, we decided to divide each 50-point area-of-concern scale into five sets of sub-categories (or buckets). Each of those five categories would be responsible for ten points. To devise these categories, we combined relevant obligations and areas of state practice. In doing so, we prioritized some obligations and practices over others. The key downside, among many, to these approaches is that our priorities and groupings reflect our assessments, as researchers, of the obligations and practices that should be prioritized and necessarily leave others out.

5. Utilizing resources that lack comprehensiveness and/or accuracy. We attempted to provisionally assess each category of state practice based on noncomprehensive resources: primary and secondary sources, including laws and regulations, news reports, and reports and figures from NGOs and government agencies. This is not a field report; it primarily reflects desk research. In assessing compliance with key FTFrelated Security Council obligations, we leaned heavily on U.S. government reports. Most of the research was conducted in English, though we benefitted from research assistance conducted in Arabic, French, and Spanish from research assistants. We conducted research from May through July 2015. 
Another possible (and related) limitation to the findings is the dynamic nature of counterterrorism law, especially as states work rapidly to implement Resolution 2178. Any changes made to counterterrorism laws or protections of humanitarian action made after July 2015 would not be reflected in our findings. Further, a state may pass counterterrorism laws individually, or incorporate them into their criminal or penal codes, or in some instances, issue royal decrees or presidential statements. The variety of ways in which the provisions of Resolution 2178 can be implemented, combined with the speed at which countries have acted to implement these laws and policies, means that the information we have for a particular state may be incomplete or have changed by the date of this report. We note that in looking for relevant laws and regulations, we not only included legislative measures put into place as a direct response to Resolution 2178 but also preexisting measures, with the understanding that the FTF environment will likely increase scrutiny and enforcement of even those laws that preceded the Security Council's FTF directives.

Finally, and perhaps most importantly, no online research platform contains accurate, up-to-date, and comprehensive national-level counterterrorism-related legislation for all U.N. member states. The U.N. Office of Drugs and Crime's Terrorism Prevention Branch has developed an important initial, and growing, set of such legislative resources. ${ }^{3}$ But that platform lacks important functionality (for instance, full documents are sometimes not available) and is not comprehensive. For all of the foregoing reasons, we acknowledge that there may be (significant) holes in the comprehensives and accuracy of our research-which is partly why we are casting our findings as provisional. We nonetheless hope that our analysis and the accompanying methodological approach spur more engagement with these topics and themes.

\section{Overcoming the lack of extensive data on foreign terrorist fighters. A} specific and significant limitation involved the (lack of) availability of concrete data on foreign terrorist fighters. We used figures from the International Centre for the Study of Radicalisation and Political Violence, whose estimates were often given as ranges that could number as large as 1,500 fighters. ${ }^{4}$ We relied on these numbers throughout our research: most notably, to help select the states we researched. As with counterterrorism

3. U.N. Office of Drugs and Crime, Terrorism Prevention Branch, "Electronic Legal Resources on International Terrorism," available online https://www.unodc.org/tldb/laws_legislative_database.html.

4. See Peter R. Neumann, Foreign Fighter Total in Syria/Iraq Now Exceeds 20,000; Surpasses Afghanistan Conflict in the 1980s, International Centre for the Study of Radicalisation and Political Violence (Jan. 26, 2015), available at http://icsr.info/2015/01/ foreign-fighter-total-syriairaq-now-exceeds-20000-surpasses-afghanistan-conflict-1980s/ (citing the number of foreign fighters from Tunisia as 1,500 to 3,000). 
law, the number of foreign fighters traveling to Iraq, Syria, and neighboring countries remains fluid, and estimates are just that: estimates. We do not know exactly how many people have become FTFs, and the number appears certain to continue increasing as time passes. As Nicholas Rasmussen, director of the U.S. National Counterterrorism Center, stated during a U.S. congressional hearing, "We know what we know, but that comes from a wide variety of sources and we have always assessed that there is likely more information out there that we have not yet been able to collect." ${ }^{5}$ He added that "it's possible that there are greater numbers of foreign fighters, and potentially even greater numbers of individuals from Western countries and the United States who've traveled to the conflict zones."

To our knowledge, this is the first effort to quantify - from legal, policy, and practical perspectives-and to evaluate quantitative evidence of compliance with Security Council counterterrorism obligations. It also appears to be the first attempt to quantify state support of principled humanitarian action in counterterrorism contexts. We see this as an initial step. We hope that our approach spurs critical discussion. And we accordingly invite others to help strengthen the underlying research approaches, evidentiary bases, and evaluative mechanisms.

\section{Provisional Assessment and Allocation of Points}

\section{Provisional Indicators of State Compliance with Five Key Foreign Terrorist Fighter Elements of Resolution 2178}

States could receive a maximum of 50 points for their compliance with the legal obligations of Resolution 2178. We divided points into five categories of obligations, each totaling ten points. As noted above, we assessed compliance with five key FTF elements of Resolution 2178 by examining primary and secondary sources, including laws and regulations, presidential statements, royal decrees, news reports, and reports by non-governmental organizations (NGOs) and government agencies, such as the U.S. Department of State's Country Reports on Terrorism. Using these sources, we conducted research through July 2015.

With the identified caveats in mind (see above), generally speaking our research found that states have acted quickly and, in some instances, forcefully to implement the relevant

5. Jamie Crawford \& Laura Koran, U.S. Officials: Foreigners Flock to Fight for ISIS, CNN News (Feb. 11, 2015), available at http:// www.cnn.com/2015/02/10/politics/isis-foreign-fighters-combat/.

6. Id. 


\section{Subcategories: Provisional Indicators of State Compliance with Five Key Foreign Terrorist Fighter Elements of Resolution 2178}

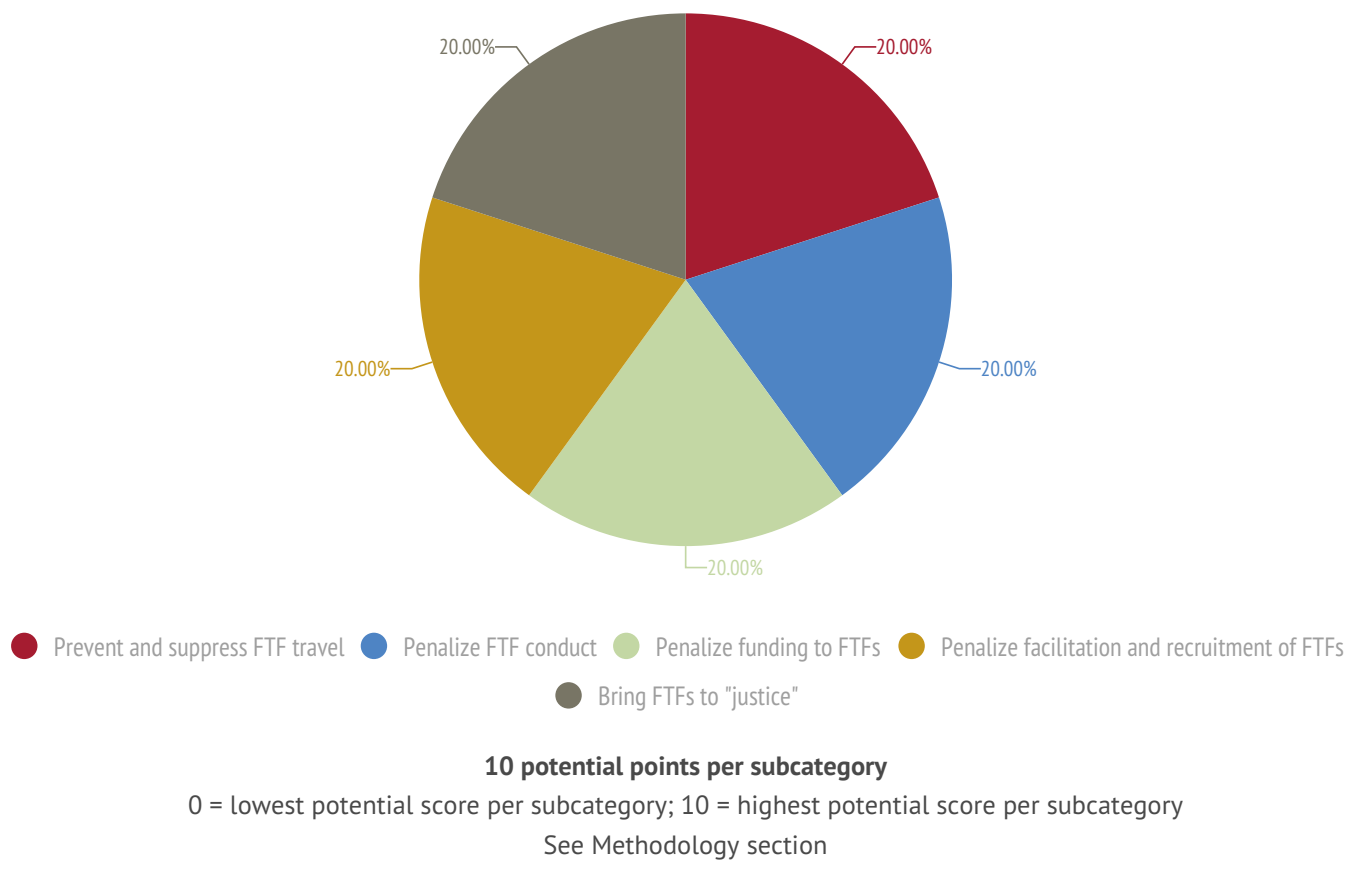

provisions of Resolution 2178. This includes the passage of new laws criminalizing the actions, travel, training, and recruitment of foreign terrorist fighters. States have also increased border security and enhanced security measures on travel documents in response to the foreign fighter threat and prosecuted individuals who are suspected to be foreign fighters.

\section{Provisional Indicators of State FTF Compliance Subcategory 1:}

\section{Prevent and Suppress Foreign Terrorist Fighter Travel}

\section{Assessment criteria}

Does the state:

i. Prevent and suppress the recruiting, organizing, transporting, equipping, and financing of FTFs;

ii. Prevent entry or transit through their territory of FTFs; and

iii. Prevent movement of terrorists or terrorist groups by effective border controls and controls on issuance of identity papers and travel documents? ${ }^{7}$

7. S.C. Res. 2178, paras. 2, 5, and 8, U.N. Doc. S/RES/2178 (Sept. 24, 2014). 


\section{Reported Foreign Fighters per Capita (per Million) for Selected States*}

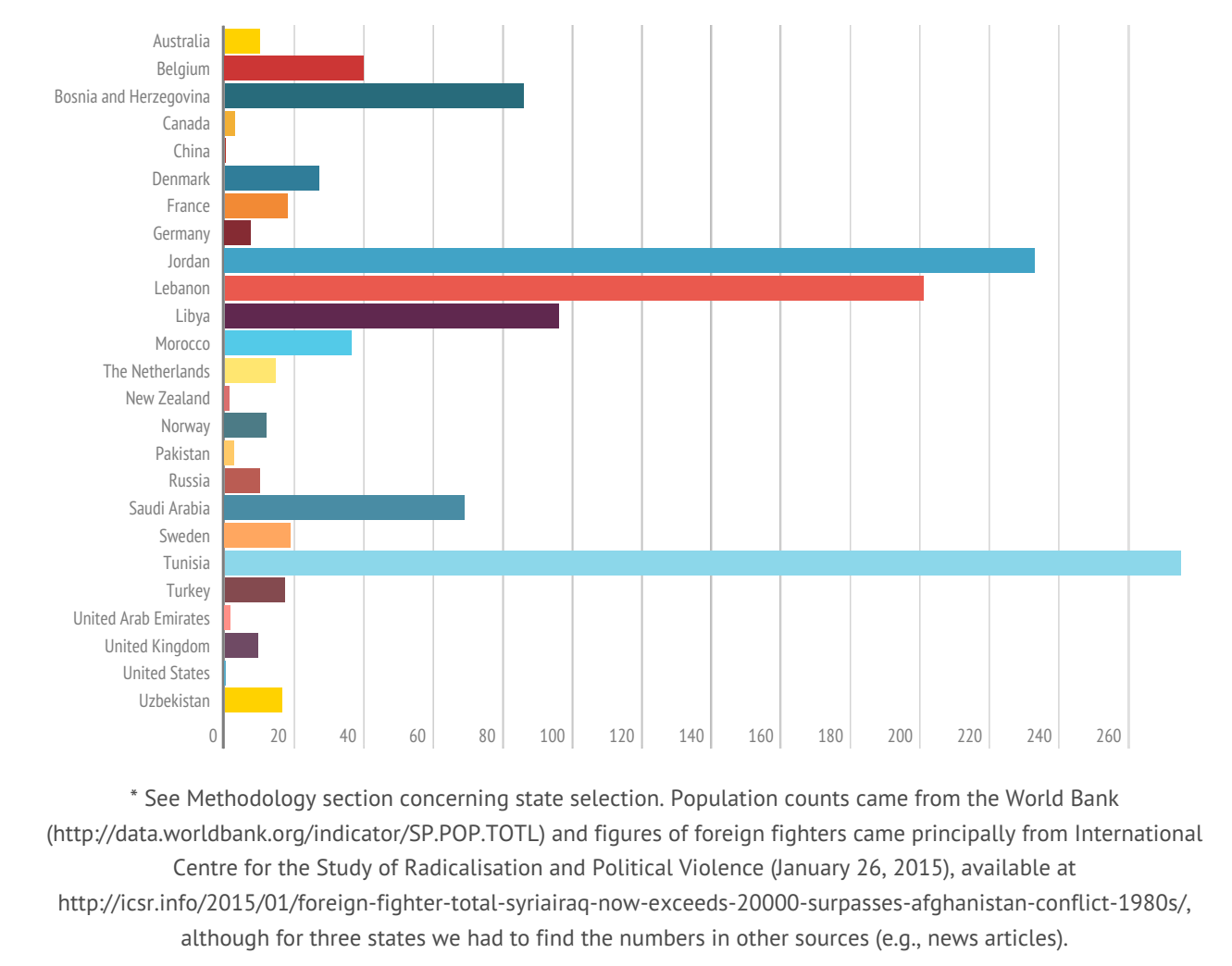

\section{Provisional Points}

We allocated up to 10 points in total for this subcategory:

8 potential points relate to the "prevent and suppress" provisions (assessment criteria i). We tabulated those points by assessing the number of reported foreign fighters per capita and dividing the countries into five tiers (with five states per tier):

8 points $=$ first tier (states with the lowest proportion of reported foreign fighters),

6 points $=$ second tier;

4 points $=$ third tier;

2 points $=$ fourth tier; and

0 points $=$ fifth tier (states with the highest proportion of reported foreign fighters).

1 point = Available evidence suggests the state sought to prevent FTFs from entering or traveling through their territory (assessment criteria ii);

1 point $=$ Available evidence suggests the state has adopted (relatively) effective border controls and controls on the issuance of identity papers and travel documents (assessment criteria iii). 


\section{Analysis}

We provisionally found that 17 of the 25 states we examined, or 68 percent, had enacted or are considering measures to "prevent and suppress the recruiting, organizing, transporting, equipping, and financing" of foreign terrorist fighters. Several states, including Germany and Saudi Arabia, enacted laws in September 2014, around the same time that the Security Council adopted the resolution. Moreover, our research found that many states under review implemented robust measures to stem the flow of foreign fighters through their countries. For instance, Australia allows for the administrative preventative detention of persons over the age of 16 to prevent them from leaving the country to commit certain acts, including engaging in hostile activity in a foreign country. ${ }^{8}$ France passed a similar law in November 2014, allowing the French government to prevent persons from leaving the country if officials suspect they are traveling to engage in terrorist activity. ${ }^{9}$ In 2015 , the United Kingdom passed a law requiring teachers, health care workers, and local government employees to inform law enforcement agencies if they suspect a young person is becoming "radicalized."10

\section{Provisional Indicators of State FTF Compliance Subcategory 2: \\ Penalize Foreign Terrorist Fighter Conduct}

\section{Assessment criterion}

Does the state ensure that domestic laws and regulations establish serious criminal offenses sufficient to provide the ability to prosecute and penalize their nationals and other individuals who travel or attempt to travel to a State other than their States of residence or nationality, for the purpose of perpetration, planning, or preparation of, or participation in, terrorist acts, or providing or receiving terrorist training ? $^{11}$

\section{Provisional Points}

For this subcategory, states could fall into one of three tiers with a maximum of 10 points:

10 points $=$ Available evidence suggests the state complied with these requirements.

6 points $=$ Available evidence suggests the state demonstrated partial compliance with the requirements, and/or efforts to implement the requirements that had not yet been fully realized.

2 points $=$ Available evidence suggests the state demonstrated little to no compliance with these requirements of the resolution.

\section{Analysis}

According to our provisional findings, punishments for foreign terrorist fighters, as well as individuals who commit acts preparatory to committing terrorist acts by traveling abroad and fighting, are generally severe. The majority of states under review impose sentences ranging from five to ten years' imprisonment for terrorist acts, including those acts associated with foreign terrorist fighters. Moreover,

8. See Appendix, Australia.

9. See Appendix, France.

10. See Appendix, United Kingdom.

11. S.C. Res. 2178, para. 6(a), U.N. Doc. S/RES/2178 (Sept. 24, 2014). 
several states have greater sentences in place for foreign terrorist fighters. For instance, Denmark prescribes a maximum of 16 years' imprisonment for recruiting others commit or to "advance" certain actions, including joining a group or association, that are proscribed under the terrorism section of the Danish Penal Code. ${ }^{12}$ Saudi Arabia prescribes a 20-year prison sentence for individuals who join extremist organizations, participate in military operations with such organizations, or support those groups, either materially or by recruiting others to join them. ${ }^{13}$ Australia prescribes a 25 -year sentence for various terrorist acts, ${ }^{14}$ and Norway prescribes a 30-year prison sentence for various terrorist acts. ${ }^{15}$ Also under Australian legislation, entering or remaining in a "declared area" of a foreign country with the intention of engaging in hostile activities is punishable by ten years' imprisonment. $^{16}$ In Tunisia, the death penalty may be imposed on individuals who commit acts of terrorism. ${ }^{17}$ Beyond imprisonment, other legal consequences facing individuals suspected to be foreign fighters include the revocation of travel documents, and even the loss of one's citizenship (if such a loss would not render the individual stateless).

While some of these laws were enacted prior to the adoption of Resolution 2178, others were implemented in response to the requirements of the resolution. The emphasis and weight that states have given to criminalizing the acts of foreign fighters evidences efforts to aggressively deter and punish those foreign terrorist fighters who participate in hostilities or take other actions preparatory to traveling to conflict zones.

\section{Provisional Indicators of State FTF Compliance Subcategory 3: \\ Penalize Funding to Foreign Terrorist Fighters}

\section{Assessment criterion}

Does the state ensure that domestic laws and regulations establish serious criminal offenses sufficient to provide the ability to prosecute and penalize the wilful provision or collection of funds by their nationals or in their territories? ${ }^{18}$

\section{Provisional Points}

States could fall into one of three tiers with a maximum of 10 points for this subcategory:

10 points $=$ Available evidence suggests the state complied with these requirements;

6 points $=$ Available evidence suggests the state demonstrated partial compliance with the requirements, and/or efforts to implement the requirements that had not yet been fully realized;

or

2 points $=$ Available evidence suggests the state demonstrated little to no compliance with these requirements of the resolution.

12. See Appendix, Denmark.

13. See Appendix, Saudi Arabia.

14. See Appendix, Australia.

15. See Appendix, Norway.

16. See Appendix, Australia.

17. See Appendix, Tunisia.

18. S.C. Res. 2178, paras. 6(b) and 12, U.N. Doc. S/RES/2178 (Sept. 24, 2014). 


\section{Analysis}

Our provisional research revealed that the laws of individual states, as well as assessments by bodies like the Financial Action Task Force (FATF), appear to indicate that most of the states under review have taken measures to protect against terrorist financing. According to the FATF and other similar bodies, however, several states-including Bosnia, Jordan, and Sweden-need to take additional steps toward preventing terrorist financing. ${ }^{19}$ Additionally, many states appear to have cooperated with each other to assist with criminal investigations relating to the financing or support of terrorist acts. This relatively high level of compliance among reviewed states may be a result of increased focus and ongoing assessments on preventing terrorist financing by groups like the FATF.

\section{Provisional Indicators of State FTF Compliance Subcategory 4: \\ Penalize Facilitation and Recruitment of Foreign Terrorist Fighters}

\section{Assessment criterion}

Does the state ensure that domestic laws and regulations establish serious criminal offenses sufficient to provide the ability to prosecute and penalize the wilful organization, or other facilitation, including acts of recruitment, by their nationals or in their territories, of the travel of individuals who travel to a State other than their states of residence or nationality for the purpose of the perpetration, planning, preparation of, or participation in, terrorist acts or the provide or receiving of terrorist training $?^{20}$

\section{Provisional Points}

For this subcategory, states could fall into one of three tiers with a maximum of 10 points:

10 points $=$ Available evidence suggests the state complied with these requirements;

6 points $=$ Available evidence suggests the state demonstrated partial compliance with the requirements, and/or efforts to implement the requirements that had not yet been fully realized; or

2 points $=$ Available evidence suggests the state demonstrated little to no compliance with these requirements of the resolution.

\section{Analysis}

Our provisional research suggests that some states appear to have not criminalized certain acts as specifically required by the resolution. This occurred most frequently with respect to the requirement to ensure that domestic laws provide the ability to "prosecute and penalize the willful organization, or other facilitation, including acts of recruitment [emphasis added]" by their citizens or within their states. Many states have criminalized recruitment, but "other facilitation" and all that it might include is less clear, and that language does not appear in many states' criminal or penal

19. See Appendix.

20. S.C. Res. 2178, para. 6(c), U.N. Doc. S/RES/2178 (Sept. 24, 2014). 
codes. The exclusion of this language may reflect ambiguity in the resolution itself, or the absence of a definition for "other facilitation." This may ultimately result in two extremes: states avoiding such broad language, or perhaps states enacting laws that broadly criminalize behavior defined as "other facilitation." In the laws we researched, relatively specific language prohibiting "support," "material support," "assistance," or "participation" appears more frequently than proscriptions on "other facilitation." At least 11 of the 25 states, or 44 percent, have adopted laws containing the former kind of language.

\section{Provisional Indicators of State FTF Compliance Subcategory 5:}

\section{Bring Foreign Terrorist Fighters to "Justice"}

\section{Assessment criterion}

Does the state ensure that any person who participates in the financing, planning, preparation, or perpetration of terrorist acts or in supporting terrorist acts is "brought to justice"?

\section{Provisional Points}

States could fall into one of three tiers:

10 points $=$ Available evidence suggests the state complied with these requirements;

6 points $=$ Available evidence suggests the state demonstrated partial compliance with the requirements, and/or efforts to implement the requirements that had not yet been fully realized; or

2 points $=$ Available evidence suggests the state demonstrated little to no compliance with these requirements of the resolution.

\section{Analysis}

Our provisional research suggests that many states have worked to "bring to justice" those involved in terrorist acts: 20 of the 25 states surveyed, or 80 percent, have prosecuted or taken other actions against suspected foreign terrorist fighters and/or individuals involved in recruitment or providing other forms of support to FTFs. Multiple states have noted difficulties, however, with successfully prosecuting individuals for these crimes due, for instance, to lack of evidence. Other reported difficulties encountered by states, including Pakistan and Tunisia, involve legal systems that may not be well equipped to handle cases brought against suspected foreign fighters. For instance, the U.S. State Department has reported that in Pakistan suspected terrorists often intimidate witnesses, the police, victims, prosecutors, and judges, which contributes to the slow progression of cases and a high acquittal rate for suspected terrorists. ${ }^{22}$ Social media also plays a notable role in some prosecutions, as states, including Denmark and Jordan, have charged individuals for posting "pro-ISIS" materials on social media websites like Facebook. ${ }^{23}$

21. S.C. Res. 2178, para. 6, U.N. Doc. S/RES/2178 (Sept. 24, 2014).

22. See Appendix, Pakistan.

23. See Appendix, Denmark and Jordan. 


\section{Provisional Indicators of Overall State Compliance with Five Key Foreign Terrorist Fighter Elements of Resolution 2178 Per Subcategory}

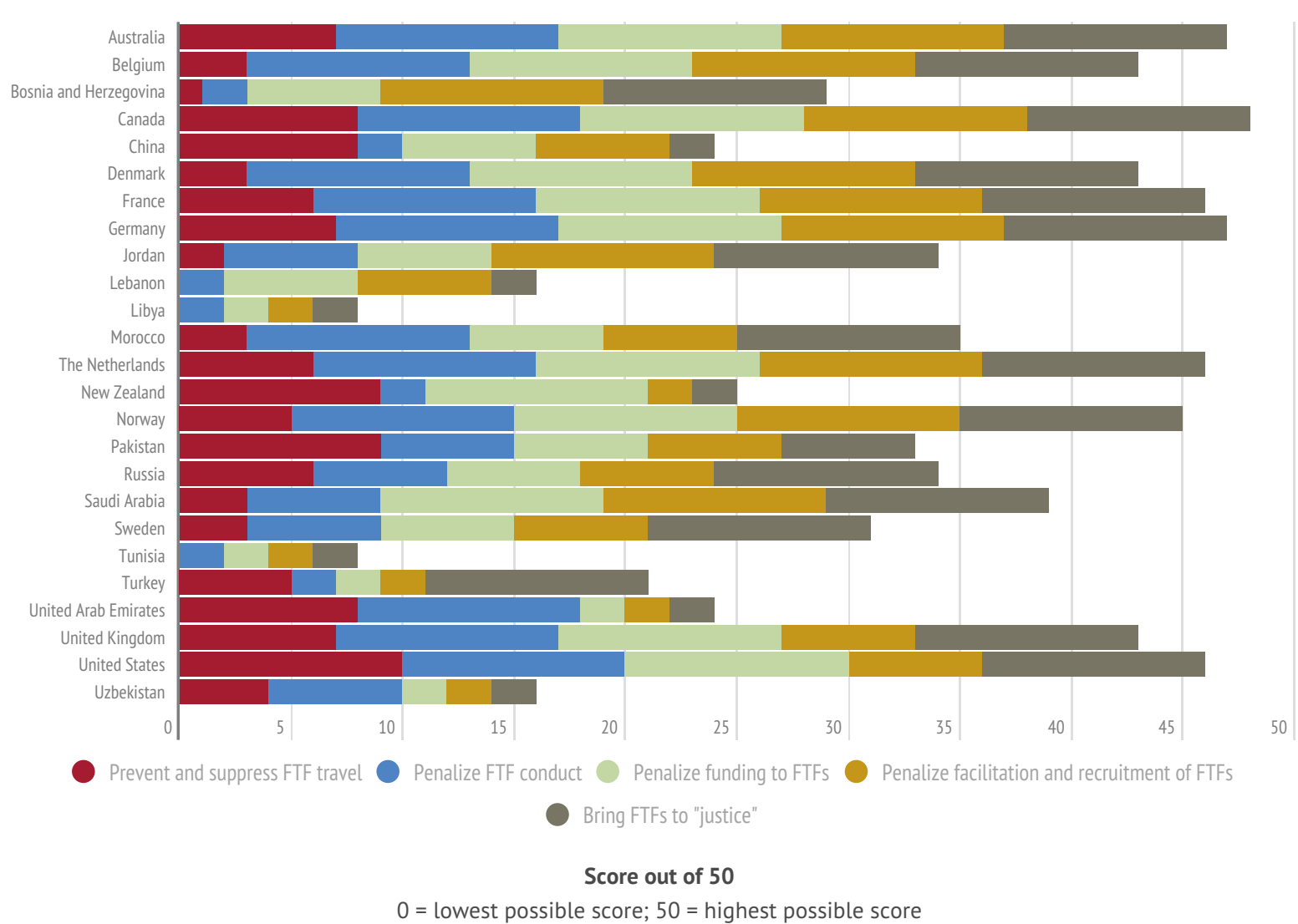

NB: Each subcategory is worth up to 10 potential points; see Methodology section

\section{Aggregate Provisional Indicators of State Compliance with Five Key Foreign Terrorist Fighter Elements of Resolution 2178}

\section{Assessment criterion}

Among the five subcategories concerning documented compliance with five key foreign terrorist fighter elements of Resolution 2178 , how many combined provisional points did the state obtain?

\section{Provisional Points}

States could in principle receive between 0 points (lowest possible score) and 50 points (highest possible score).

\section{Analysis}

Our provisional research suggests that many of the states under review have implemented the bulk of the highlighted FTF provisions of Resolution 2178, responding rapidly and robustly to the 


\section{Heat Map: \\ Provisional Indicators of Overall State Compliance with Five Key Foreign Terrorist Fighter Elements of Resolution 2178 per Tier}

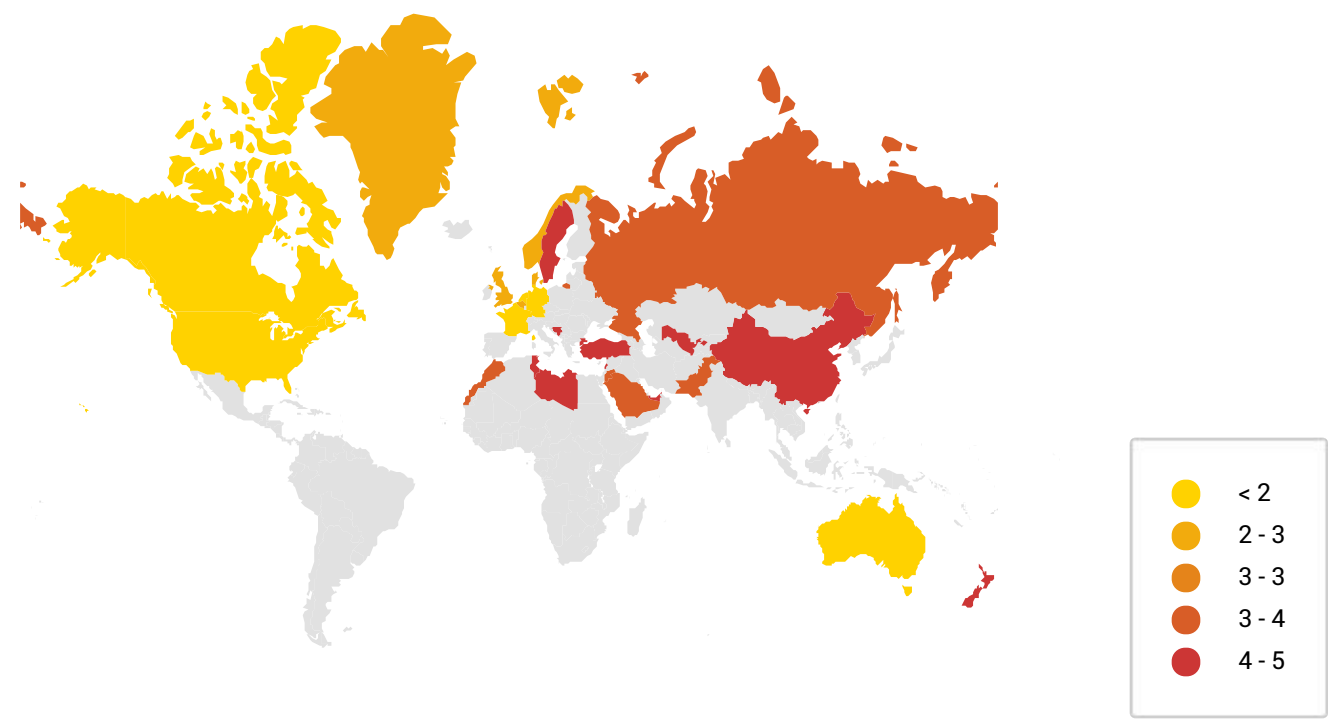

25 States in Total • Five Tiers in Total • Five States per Tier (Rounded)

1 = Highest-scoring Tier (highest provisional overall scores)

5 = Lowest-scoring Tier (lowest provisional overall scores)

threat of foreign terrorist fighters as identified by the U.N. Security Council. Nonetheless, under the applied methodology, a handful of the reviewed states have taken relatively fewer documented steps to comply with the key FTF elements of Resolution 2178. Additional research would be useful in two areas: first, the relative speed of implementation of these obligations, and second, how states themselves understand and interpret Security Council-imposed counterterrorism obligations requiring that states bring their respective domestic legislation into alignment with the relevant resolution. One potential reason, for instance, why some states may not be fully complying is because they lack the legal and institutional infrastructure necessary to do so. But another reason might be that these states have normative conflicts between their domestic constitutional system and some aspects (particularly the more vague aspects) of the obligations entailed in Resolution 2178. Alternatively, a state may be interpreting the resolution in a way that would not create additional obligations beyond the state's extant generic anti-terrorism laws. 


\section{Provisional Indicators of State Support of Five Key Aspects of Principled Humanitarian Action in Counterterrorism Contexts}

According to our scale, states could receive a maximum of 50 points for supporting principled humanitarian action in counterterrorism contexts. For this main category, we divided points into five subcategories, each worth up to ten points. As noted above, we assessed these subcategories by examining primary and secondary sources, including laws and regulations, presidential statements, royal decrees, news reports (primarily in English), and reports by non-governmental organizations (NGOs) and government agencies, such as the U.S. Department of State's Country Reports on Terrorism. We also used data from the World Bank and the United Nations Financial Tracking Service. Using these sources, we conducted research through July 2015. Our provisional findings concerning state support of principled humanitarian action in counterterrorism contexts should be read with the caveats and limitations provided in the methodology section above.

\section{Provisional Indicators of State Support of Key Aspects of Principled Humanitarian Action in Counterterrorism Contexts Subcategory 1: Knowability of Anti-Terrorism Lists}

\section{Assessment criteria}

Are the domestic anti-terrorism list(s) (including those implementing Security Council al-Qaeda sanctions) and the requisite measures relating to that list/those lists publicly available?

\section{Provisional Points}

For this subcategory, states could receive 10,5 , or 0 points:

10 points $=$ Available evidence suggests that such list(s) are publicly available and discernable;

5 points $=$ Available evidence suggests that such list(s) are somewhat publicly available and/or partially discernible; or

0 points $=$ Available evidence suggests that such list(s) are not publicly available or are not discernible.

\section{Analysis}

Having publicly available terrorist lists helps allow humanitarian organizations to conduct thorough and accurate vetting of local partners and to comply with counterterrorism-related internal or external due diligence requirements. (For the purposes of this report, we do not address potential human rights or other concerns regarding the validity, scope, and enforcement mechanisms associated with the Security Council's or an individual state's respective counterterrorism lists.) Our provisional research indicates that many states maintain transparent and publicly available terrorist lists that aim 


\section{Subcategories: Provisional Indicators of State Support of Five Key Aspects of Principled Humanitarian Action in Counterterrorism Contexts}

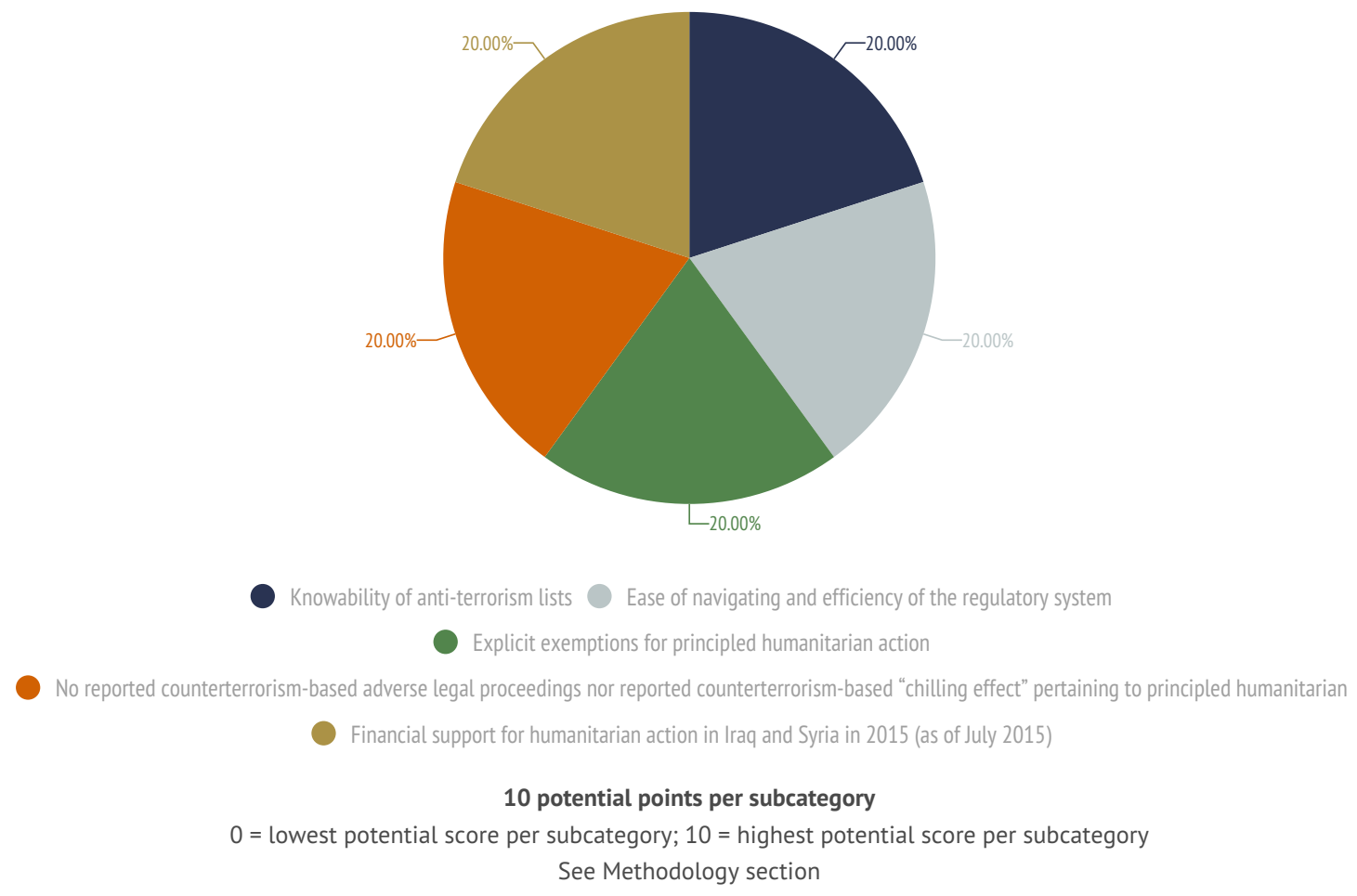

to comply with the relevant U.N. counterterrorism resolutions. In addition, the European Union has developed a terrorist list that binds its member states. Some European Union members, such as the Netherlands and Sweden, also maintain their own domestic lists. ${ }^{24}$ The United States even maintains multiple domestic terrorist lists. ${ }^{25}$ While states generally provided publicly accessible terrorist lists, the multitude of terrorist lists - and some states' extraterritorially applicable counterterrorism lawsstill present humanitarian actors with a complex and potentially confusing array of designations. Additional research on the issue of counterterrorism-related legal fragmentation and legal obligations emanating from multiple jurisdictions would be useful.

\section{Provisional Indicators of State Support of Key Aspects of Principled Humanitarian Action in Counterterrorism Contexts Subcategory 2: Ease of Navigability and Efficiency of the Regulatory System}

\section{Assessment criterion}

Are regulations relating to funding, registration, and/or financial reporting navigable and is the regulatory system efficient?

24. See Appendix, the Netherlands and Sweden.

25. See Appendix, United States. 


\section{Provisional Points}

States could receive up to 10 points for this subcategory:

10 points $=$ Available evidence suggests the relevant portions of the regulatory system are relatively easy to navigate and efficient;

5 points $=$ Available evidence suggests the relevant portions of the regulatory system are relatively challenging to navigate and/or relatively inefficient; or

0 points $=$ No evidence suggests the relevant portions of the regulatory system are relatively easy to navigate and/or efficient, or available evidence suggests these portions of the regulatory system are relatively difficult to navigate and/or inefficient.

\section{Analysis}

According to our provisional analysis, a large majority of states under review appear to institute, for non-profit organizations, regulatory systems that are fairly easily navigable and efficient. As these provisional assessments do not focus on humanitarian organizations in particular but rather on nonprofit organizations in general, this is a significant limitation to our analysis. Some states-such as the United States and those states whose funding is made available through regional bodies, such as the European Union-may impose relatively more onerous reporting requirements, but the format, methodology, and justification of those reporting requirements are comparatively clear, and thus organizations may be able to predict how much work it will take to comply with those requirements. As seen primarily through the lens of information provided by the International Center for Notfor-Profit Law (ICNL), multiple states impose relatively less efficient and more-difficult-to-navigate regulatory systems for non-profit organizations, with respect to funding, registration, and financial reporting. Additional research that focuses more on the relative ease of navigability and efficiency of the regulatory system for humanitarian organizations in particular would strengthen the basis here for comparative assessment. ${ }^{26}$

\section{Provisional Indicators of State Support of Key Aspects of Principled Humanitarian Action in Counterterrorism Contexts Subcategory 3:}

\section{Explicit Exemptions from Counterterrorism Measures of Principled Humanitarian Action}

\section{Assessment criteria}

i. Does domestic legislation limiting travel to conflict zones involving terrorists exempt staff of principled humanitarian organizations (expressly or as a subset of non-profit organizations) automatically (or potentially through a petition/license);

26. See Financial Action Task Force, Risk of Terrorist Abuse in Non-Profit Organisations (June 2014) 1, http://www.fatf-gafi. org/media/fatf/documents/reports/Risk-of-terrorist-abuse-in-non-profit-organisations.pdf (stating that nonprofit organizations (NPO) most at risk of abuse by terrorist organizations "appear to be those engaged in 'service' activities, and that operate in a close proximity to an active terrorist threat. This may refer to an NPO operating in an area of conflict where there is an active terrorist threat. However, this may also refer to an NPO that operates domestically, but within a population that is actively targeted by a terrorist movement for support and cover. In both cases the key variable of risk is not geographic, but the proximity to an active threat."). 
ii. Does domestic legislation (applicable within the territory of the state and/or extraterritorially) restricting engagement with terrorists exempt impartial wartime medical care for terrorists; and iii. Does domestic legislation exempt other forms of principled humanitarian action in conflict zones involving terrorists?

\section{Provisional Points}

States could receive the following points (up to 10 in total) for this subcategory:

Up to 3 points for assessment criterion i:

3 points $=$ Available evidence suggests the state has promulgated this exemption/these exemptions;

1-2 points $=$ Available evidence suggests the state has promulgated partial versions of this exemption/these exemptions; and

0 points $=$ No available evidence suggests that the state has promulgated partial or full versions of this exemption/these exemptions.

Up to 3 points for assessment criterion ii:

3 points $=$ Available evidence suggests the state has promulgated this exemption/these exemptions;

1-2 points $=$ Available evidence suggests the state has promulgated partial versions of this exemption/these exemptions; and

0 points $=$ No available evidence suggests that the state has promulgated partial or full versions of this exemption/these exemptions.

Up to 4 points for assessment criterion iii:

4 points $=$ Available evidence suggests the state has promulgated this exemption/these exemptions;

1-3 points $=$ Available evidence suggests the state has promulgated partial versions of this exemption/these exemptions; and

0 points $=$ No available evidence suggests that the state has promulgated partial or full versions of this exemption/these exemptions.

\section{Analysis}

Our provisional research suggests that only four of the 25 states reviewed, or 12 percent, have legislation containing explicit exemptions from counterterrorism measures for principled humanitarian action. For instance, Australia has exempted the travel of individuals to conflict zones in foreign countries if such travel seeks to provide "aid of a humanitarian nature." Australian law prohibiting association with terrorist organizations also exempts humanitarian assistance. ${ }^{27}$ Canadian law specifies that

27. See Appendix, Australia. 
"terrorist activity" does not include acts conducted in accordance with customary international law or conventional international law applicable to the conflict, which may be interpreted to encompass certain aspects of principled humanitarian action. ${ }^{28} \mathrm{New}$ Zealand allows for the provision of food, clothing, or medicine to designated terrorist entities, insofar as such assistance "does no more than satisfy essential human needs" of the designated individual. ${ }^{29}$ Finally, the United States exempts the provision of medicine and religious materials in its material support law, and the U.S. Department of Treasury can issue licenses to individuals or organizations seeking to engage in otherwise prohibited activities. $^{30}$

Our provisional research did not uncover, for the remaining 21 surveyed states, any explicit exemptions from counterterrorism measures for principled humanitarian action. To be clear, however, that does not mean that relevant forms of principled humanitarian action are not exempted under those states' respective counterterrorism measures. It may be the case that there are valid reasons why a particular state does not expressly exempt various forms of principled humanitarian action from counterterrorism legislation. Depending on the domestic legal system, a state may not need to explicitly exempt certain conduct for that conduct not to fit within the definition of a proscribed counterterrorism offense. More specifically, the relevant counterterrorism legislation may already be narrowly crafted in such a way that all forms of principled humanitarian action are excluded from its ambit and thus an exemption is not required. For example, the legislation prohibiting support to terrorism may clearly require an intent to support violent terrorism or to further the terrorist objectives of the proscribed group, or the legislation may not define association with or coordination with designated groups in such a manner that humanitarian negotiations could be reasonably interpreted to fall within the ambit of the underlying support-for-terrorism offense. (Though it could also be the case that an exemption, even where not necessarily legally required, provides a reaffirmation and assurance of the unique nature of principled humanitarian assistance.) Further state-specific research with respect to this subcategory would be useful.

\section{Provisional Indicators of State Support of Key Aspects of Principled Humanitarian Action in Counterterrorism Contexts Subcategory 4: No reported legal proceedings on the basis of principled humanitarian action in conflict zones involving terrorists nor reported "chilling effect" of principled humanitarian action due to state counterterrorism measures}

\section{Assessment criteria}

i. Have (current or former) staff of principled humanitarian organizations been subject under the jurisdiction of the state to civil or criminal proceedings on the basis of engaging in principled humanitarian action in conflict zones involving terrorists; and

ii. Does the state's domestic counterterrorism legislation have a reported "chilling effect" (selfimposed curtailment) on principled humanitarian organizations?

28. See Appendix, Canada.

29. See Appendix, New Zealand.

30. See Appendix, United States. 


\section{Provisional Points}

States could receive the following points (up to 10) for this subcategory:

Up to 5 points for assessment criteria i:

5 points $=$ No available evidence suggests the state has subjected the staff of principled humanitarian organizations to civil or criminal proceedings based on their engagement in principled humanitarian action in conflict zones involving terrorists; or

0 points $=$ Available evidence suggests the state has subjected the staff of principled humanitarian organizations to civil or criminal proceedings based on their engagement in principled humanitarian action in conflict zones involving terrorists.

Up to 5 points for assessment criteria ii:

5 points $=$ No available evidence suggests the state's domestic counterterrorism legislation has resulted in a self-imposed curtailment of humanitarian action; or

0 points $=$ Available evidence suggests the state's domestic counterterrorism legislation has resulted in a self-imposed curtailment of humanitarian action.

\section{Analysis}

As used in this report, a "chilling effect" is a publicly documented self-imposed curtailment of principled humanitarian action by a humanitarian organization in relation to an armed conflict involving terrorists due to a specific state's (or set of states') counterterrorism measure(s). We attempted to document them because, to date, the potential for such "chilling effects" has been framed as one of the key examples of the negative impact of counterterrorism measures on humanitarian action. ${ }^{31}$ With the caveats noted below in mind, our provisional research did not uncover a significant body of evidence establishing that humanitarian organizations have publicly reported that the counterterrorism measures of a specific state (or a group of states) have resulted in or otherwise contributed to such chilling effects. In accordance with the methodology for this report, most states therefore provisionally received the full 10 available points for this category.

What should we make of this provisional analysis? The relative lack of documented "chilling effects" in this category does not mean that there necessarily are no such effects. Humanitarian actorsincluding, as noted above, the ICRC - have specifically connected counterterrorism measures to (potential and/or real) adverse impacts on humanitarian action. It may be that it is, in general, difficult to quantify or otherwise measure the prevalence of relevant legal proceedings (whether criminal or civil). For instance, there are examples of designations of and the institution of legal proceedings against individuals who work for putative "humanitarian" organizations, but the available record may not clearly establish whether those individuals or organizations were "principled" humanitarian organizations in the sense used here. Moreover, the very question of impact-what counts as impact and how to measure impact-remains a matter of debate for which there have been relatively few efforts to establish consensus within the humanitarian community. As a result, currently we do not have

31. See Kate Mackintosh \& Patrick Duplat, Study of the Impact of Donor Counter-Terrorism Measures on Principled Humanitarian Action, OCHA and the NRC (July 2013), at 84 (defining "chilling effects" as situations where "[o]perational decisions were made not strictly according to need but, in part, to minimise organisations' exposure to legal liability."). 
a reliable way of knowing how many projects an organization does not propose or carry out (despite concluding that such a project would be necessary) due to their concerns about counterterrorism measures. Nor, similarly, do we know whether there are staff that do not undertake a field mission due to such concerns. In short, the main issue here may very well be a lack of underlying sources, despite the reported importance of this category among humanitarian actors.

In a similar vein, it could be that the humanitarian community has not devised a quantifiable way to document such impacts. Indeed, it may be particularly difficult to measure this type of chilling effect from counterterrorism measures-or to measure chilling effects in general. Merely by discussing their concerns around chilling effects, humanitarian organizations may fear being accused of unlawfully supporting terrorists (even where those humanitarian actions are protected under IHL). They may also fear retribution from host states, or dwindling financial support from states and other donors. More generally, it is of course much more difficult to measure negative action (in the sense of a selfimposed curtailment) than positive action.

Nonetheless, it is important to bear in mind that some evidence of the humanitarian community's response to recent crises, such as Somalia, illustrates the fact that counterterrorism policies may indeed operate in a way that leads to self-imposed curtailments of humanitarian assistance. With all of these concerns in view, policymakers and those seeking to evaluate the scope and impact of counterterrorism policies on principled humanitarian action would benefit from more documentation (more in terms of amount and specificity) of such putative chilling effects. For as long as the impact of "chilling effects" remains in the realm of anecdote, it may be difficult for humanitarian actors to mobilize meaningful solutions on the part of governments and intergovernmental bodies such as the Security Council.

\section{Provisional Indicators of State Support of Key Aspects of Principled Humanitarian Action in Counterterrorism Contexts Subcategory 5:}

Financial Support for Humanitarian Action in Iraq and Syria

\section{Assessment criterion}

What amount of international humanitarian aid contributions, as a percentage of GDP, has the state contributed to Iraq and Syria in 2015 (as of July 2015)?

\section{Provisional Points}

For this subcategory, we used World Bank population data ${ }^{32}$ and Financial Tracking Service data ${ }^{33}$ to put states into one of five tiers and to allocate an accompanying set of points, with up to 10 points in total:

10 points $=$ Tier 1 -states with highest reported humanitarian funding contributions to Iraq and Syria in 2015 (as of July 2015) as a percentage of GDP;

8 points $=$ Tier 2 ;

6 points $=$ Tier 3 ;

32. See http://data.worldbank.org/indicator/NY.GDP.MKTP.CD.

33. See https://fts.unocha.org/pageloader.aspx?page=search-customsearch. 


\section{Provisional Indicators of Overall State Support of Five Key Aspects of Principled Humanitarian Action in Counterterrorism Contexts Per Subcategory}

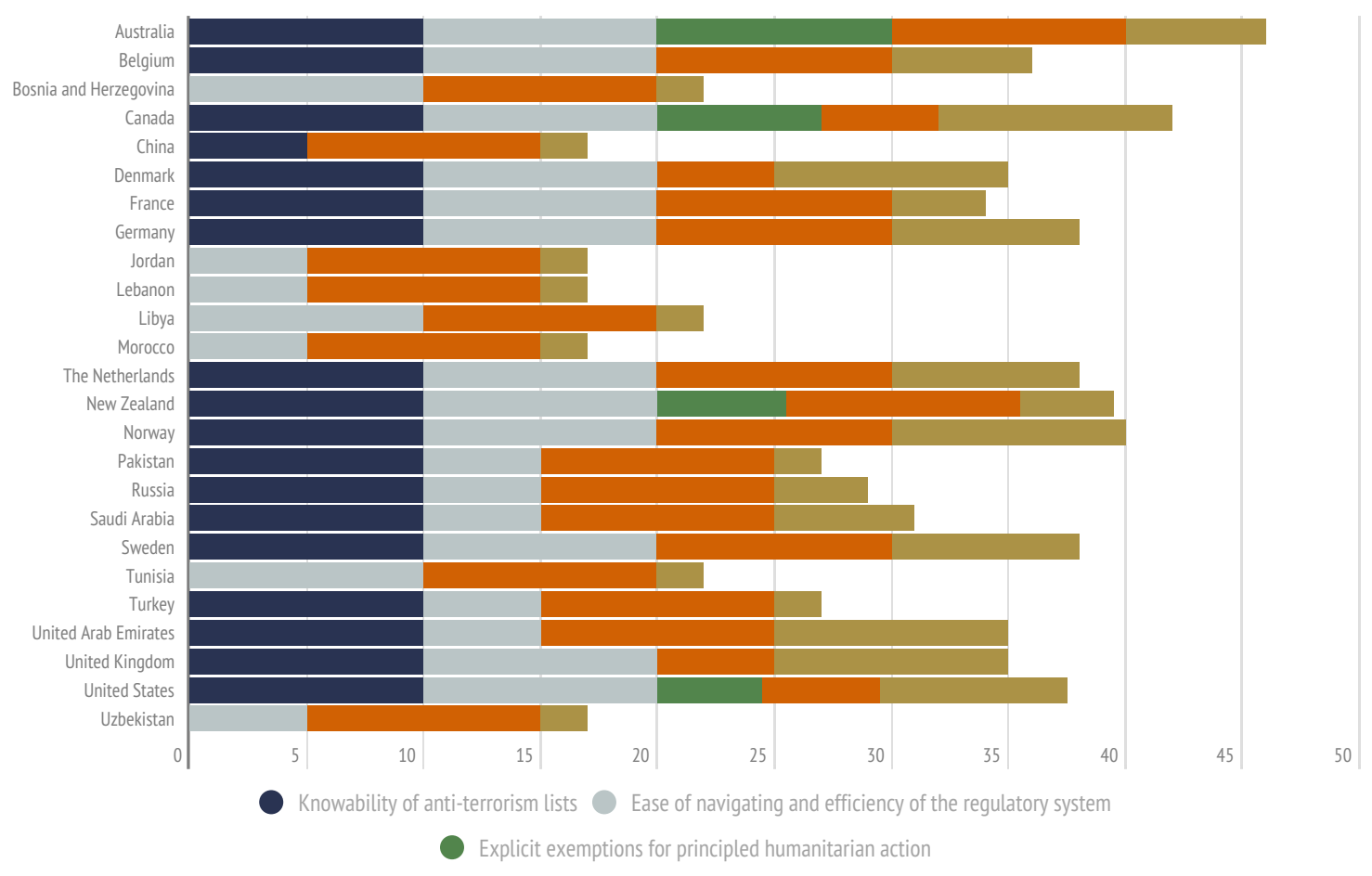

No reported counterterrorism-based adverse legal proceedings nor reported counterterrorism-based "chilling effect" pertaining to principled humanitarian

Financial support for humanitarian action in Iraq and Syria in 2015 (as of July 2015)

Score out of 50

$0=$ lowest possible score; 50 = highest possible score

NB: Each subcategory is worth up to 10 potential points; see Methodology section

4 points $=$ Tier 4 ; or

2 points $=$ Tier 5-states with lowest reported humanitarian funding contributions (if any) to Iraq and Syria in 2015 (as of July 2015) as a percentage of GDP.

\section{Analysis}

In examining the amount of international humanitarian aid contributions that states have provided to Iraq and Syria (the two states where the terrorist organizations that Resolution 2178 aims to suppress hold the greatest amount of territory) from January to July 2015, we added financial support captured in the Financial Tracking Service made to both of those states and calculated that amount as a percentage of the contributing state's GDP. We assigned provisional points by dividing states into five tiers based on the percentage of GDP that states provided to Iraq and Syria, with states making the greatest recorded financial contributions receiving ten points, and states making the smallest (or no) financial contributions receiving two points. Canada, Denmark, Norway, the United Arab Emirates, and the United Kingdom received ten points each, while Bosnia, China, Jordan, Lebanon, 


\section{Heat Map: \\ Provisional Indicators of Overall State Support of Five Key Aspects of Principled Humanitarian Action in Counterterrorism Contexts per Tier}

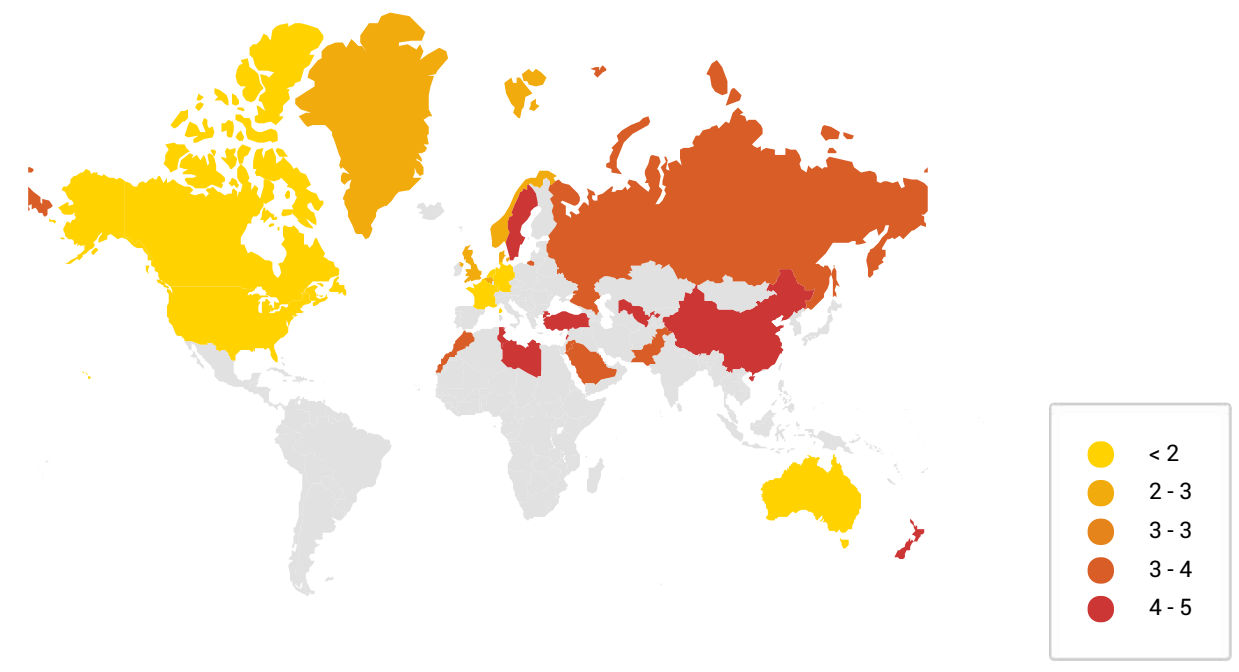

25 States in Total • Five Tiers in Total • Five States per Tier (Rounded)

1 = Highest-scoring Tier (highest provisional overall scores)

5 = Lowest-scoring Tier (lowest provisional overall scores)

Libya, Morocco, Pakistan, Tunisia, Turkey, and Uzbekistan received two points because they did not make any financial contributions captured in the Financial Tracking Service to either Iraq or Syria from January to July 2015.

\section{Aggregate Provisional Indicators of State Support of Principled Humanitarian} Action in Counterterrorism Contexts

\section{Assessment criterion}

Among the five subcategories concerning support of principled humanitarian action in counterterrorism contexts, how many combined points did the state obtain?

\section{Provisional Points}

States could in principle receive between 0 points (lowest possible score) and 50 points (highest possible score).

\section{Analysis}

Generally speaking, our provisional research suggests that many of the states under review have supported principled humanitarian action in counterterrorism contexts, yet there is a significant range of such support under the applied methodology. 


\section{4}

\section{CONCLUSION}

\section{Opportunities and Concerns for Principled Humanitarian Organizations}

State responses to foreign terrorist fighter-related threats may ultimately sharpen existing concerns-or even pose new concerns-for principled humanitarian actors. However, it is not clear, at this early stage in the development of the "foreign terrorist fighter" concept, that state responses to the threat posed by FTFs necessarily will adversely affect principled humanitarian action. Both potential opportunities and concerns are on the horizon.

As noted above, the Security Council expressly required that U.N. member states prevent and suppress the recruiting, organizing, transporting, or equipping of FTFs consistent with IHL. ${ }^{1}$ In doing so, the Council provided an explicit basis on which principled humanitarian actors can call upon states to ensure that measures aimed at preventing and suppressing FTFs do not impede humanitarian action protected under IHL.

Today, the overall political and operational environment for principled humanitarian action appears to marked by increasingly aggressive counterterrorism responses. It may well be that donor states, states in the region, and states with comparatively greater numbers of FTFs experience the FTF threat as presenting a different order of national security concern than does terrorism more generally. Perhaps particularly in light of recent ISIS developments, refugee influxes into Europe, and al-Qaeda calling for lone-perpetrator attacks in the West, state responses appear to be tipping increasingly towards national security. These changing political realities should inform how humanitarian organizations understand the potential for additional changes to the regulatory environment. In particular, on the horizon there are six areas humanitarian actors should be particularly aware of and engaged with.

1. S.C. Res. 2178, para. 5, U.N. Doc. S/RES/2178 (Sept. 24, 2014). 


\section{Heightened administrative and programmatic burdens on humanitarian organizations in terms of their vetting and due diligence responsibilities}

Humanitarian organizations may see new vetting and new approval requirementsadopted pursuant to frameworks implementing the FTF measures entailed in Resolution 2178- specifically related to areas controlled by ISIS. Donors may, for instance, begin to request new forms of project approval and new forms of oversight, such as by requiring pre-approval by the donor of each new partner.

\section{Decreased freedom of movement of humanitarian personnel}

To effectively pursue their objectives, humanitarian actors often need to be able to deploy quickly and move as efficiently as possible into and within conflict zones. FTFrelated measures may subject humanitarian personnel to new or heightened restrictions on travel, visa issuances, and border-crossings.

\section{Increased governmental scrutiny of national and regional staff}

States with greater numbers of individuals allegedly traveling from their territory to become FTFs may be particularly sensitive to their nationals traveling to Iraq and Syria. At the same time, humanitarian staff from those states with more FTFs may be particularly crucial for effectively addressing humanitarian needs, perhaps especially in ISIS-controlled areas. Frameworks devised to implement anti-FTF measures may lead to an increase in intelligence-gathering activities in affected regions. But those measures may undermine humanitarian actors' relationships with local communities and local partner organizations.

\section{Decreased access to financial services and funding channels}

Recently, there has been more research focusing on the financing of humanitarian action in relation to armed conflicts involving designated terrorists, including with respect to banks'"de-risking" from such areas. As noted above, Resolution 2178 imposes an obligation on states to prevent the financing of FTFs in particular (building on earlier obligations to prevent funding of terrorism more generally). Against the backdrop of greater legal and regulatory scrutiny concerning FTF threats, banks and other financial institutions may become more reticent to provide financial services and to facilitate financial transactions concerning situations of armed conflict involving designated groups. Financial institutions may be particularly reticent to provide services for 
organizations working in territories (including currently parts of Iraq and Syria) controlled not just by listed groups but by groups that appear to be recruiting FTFs from around the world. Financial institutions may devise new mechanisms for reviewing and vetting activities in areas that are considered high risk from an FTF perspective.

\section{Elevated concerns regarding reputational harm}

Humanitarian actors may face increased public concern regarding groups traveling to areas controlled by ISIS because of increased media and governmental attention to the national security threats posed by FTFs. Framed in this way, the FTF threat may decrease public appreciation for humanitarian action and humanitarian needs, causing increased risks in terms of reputational harm. Where the public is hearing about tens of thousands of people traveling to fight on behalf of designated groups, and about individuals potentially returning home with fighting skills, as well as a surge of refugees seeking entry to those countries, there may be less understanding of humanitarian organizations that need to travel to and work in territories controlled by these groups. In such an environment, humanitarian actors may decide to invest additional resources into public education, awareness raising, and outreach.

\section{Decreased autonomy of action with respect to engagement with all parties to armed conflict}

At the root of principled humanitarian action is the so-called right of humanitarian initiative, pursuant to which humanitarian organizations may offer their services to all parties to armed conflict. So far, many governments have emphasized that principled humanitarian engagement with listed entities is not as such prohibited. But that may change as states are increasingly focused on FTF threats. There is a risk that some laws related to preventing and prosecuting FTFs-some building on preexisting counterterrorism measures, others new-would in fact make it unlawful to engage with certain proscribed groups. (There may also be an understandable chilling effect in terms of engaging directly with ISIS and other groups accused of recruiting or using FTFs.) Due to concerns over recruitment of FTFs over social media, states are likely to engage in more scrutiny of communications into and out of Iraq and Syria (and other territories where ISIS may gain control or exert significant influence) in the future. Free and unhindered humanitarian engagement and dialogue with such groups or their representatives may become unacceptable to Western and regional governments. For some, the line between talking to proscribed groups for purposes of recruitment and 
talking to them for purposes of humanitarian negotiations may just be too fine of a distinction for counterterrorism laws to capture, particularly at a time when national security concerns are running so high.

\section{Recommendations to Strengthen EvidenCE-BASEd DeCISION-MAKING}

How could a better understanding of the relevant trends and trajectories -in state responses to the threats posed by foreign terrorist fighters, in state support of principled humanitarian action in counterterrorism contexts, and, especially, in the potential intersections between those areas of state practice-be established? Four areas may be particularly impactful to focus on in the current environment.

\section{Evidence of and data on compliance with Security Council counterterrorism measures}

Make assessments of state compliance with binding Security Council counterterrorism measures publicly available. Researchers currently lack systematic, up-to-date, and comprehensive qualitative and quantitative assessments of individual state compliance with Security Council counterterrorism measures. ${ }^{2}$ Certain Security Council anti-terrorism bodies are already tasked with making such assessments. For example, in Resolution 2178 the Security Council requested that the Counter-Terrorism Committee, with the support of the Counter-Terrorism Executive Directorate, "identify principal gaps" in U.N. member states' capacity to implement certain key binding counterterrorism decisions that may hinder states' "abilities to stem the follow of foreign terrorist fighters." ${ }^{3}$ In monitoring member states' compliance with Resolution 1373 (2001), as of 2013 the Counter-Terrorism Committee had conducted visits to 88 states. ${ }^{4}$ But for the most part those assessments

2. In Resolutions 1373 (2001) (para. 6) and 1624 (2005) (para. 5), the Security Council requested that states report to the Counter-Terrorism Committee regarding the steps taken to comply with those resolutions. While the resulting reports are useful, they suffer three key weaknesses: (1) many states did not self-report (or at least those reports were not made publicly available); (2) the reports relate to compliance only with Resolutions 1373 and 1624; and (3) by now, the vast majority of these reports are outdated.

3. S.C. Res. 2178, para. 24, U.N. Doc. S/RES/2178 (Sept. 24, 2014). If the CTC is not in a position to make the full reports public, it would nonetheless be useful if it explained what needs to remain classified and then provided a database on what could be public (for example, the relevant legislation of every reviewed state).

4. Counter-Terrorism Committee, Annex - Report of the Security Council Committee established pursuant to resolution 1373 (2001) concerning counter-terrorism to the Security Council for its comprehensive consideration of the work of the Committee and its Executive Directorate from 2011 to 2013, Dec. 11, 2013, UN doc. S/2013/722, para. 10. 
concerning an individual state's level of compliance with the pertinent counterterrorism resolution are not made publicly available. If those bodies are not in a position to make those assessments publicly available, then other bodies, states, or civil society actors could make their own evaluations.

More transparency and reliable data on state compliance with Security Council counterterrorism obligations would allow states-as well as academic researchers and other members of civil society-to more accurately assess and evaluate the utility, impact, and cost-effectiveness of these measures. In this paper, we put forward a provisional assessment framework; we hope our analysis will spur further interest in and catalyze the development of additional metrics and the systematic accumulation of new evidence and data in this key area of contemporary state practice.

\section{Monitoring compliance with relevant (additional) fields of international law}

Foster discussion and consensus on what it means to comply with IHL, IHRL, and IRL when discharging Security Council-imposed counterterrorism obligations, and make assessments of such compliance publicly available. Resolution 2178 (2014) and many other counterterrorism resolutions impose obligations on states to discharge their counterterrorism obligations in ways that comport with other fields of international law, such as international human rights law (IHRL), IHL, and international refugee law (IRL). But what, exactly, does that mean in practice? By what metrics could we actually measure whether a state is preventing and suppressing FTFs, for instance, consistently with IHL, IHRL, and IRL? To answer that question, we need an authoritative interpretation of what compliance with those legal frameworks would actually entail-not only in principle but also in practice-in implementing counterterrorism measures.

The Counter-Terrorism Committee, with the support of the Counter-Terrorism Executive Directorate (which already has a senior human rights officer), may be particularly well-placed to foster a discussion, as well as to solicit the views of member states and the Security Council, on this issue. At a minimum, it would be useful if the Security Council and its relevant counterterrorism bodies provided a clear written explanation of how they interpret the IHL, IHRL, and IRL obligations-in principle and how they would operate in practice-in the context of the Council's counterterrorism resolutions. That explanation could then be incorporated into relevant technical assistance. Once devised, that explanation should be made publicly available, alongside the accompanying data and evidence on the extent to which states are-or are not- 
actually complying with those additional frameworks in implementing counterterrorism measures. Short of decision guidance and monitoring by a relevant Security Council body, other states or civil society actors may put forward their own interpretations and their own monitoring mechanisms. In the same vein, other bodies that monitor compliance with counterterrorism measures - such as the FATF-may consider similarly including evaluations of state compliance with other applicable fields of international law (especially IHL, IHRL, and IRL).

\section{Potential exemptions in counterterrorism measures for principled humanitarian action}

Evaluate whether to draft model exemptions from counterterrorism obligations for principled humanitarian action. One of the more striking results of our provisional analysis is that most of the reviewed states do not explicitly exempt from their counterterrorism legislation principled humanitarian action-even where anti-terrorism measures apply to situations of armed conflict and where the relevant form of principled humanitarian action is protected under IHL. There has been a significant amount of discussion over the past year about the possibility of exemptions and exceptions as a potential solution to the dilemmas posed when counterterrorism policies and humanitarian action intersect. Yet, to date, these discussions have been typically based on vague references to the notion of exemptions rather than actual concrete examples of what such legal texts might look like and how they might function. This lack of concreteness may have contributed to a sense that states are not willing to engage the notion of exemptions, or that humanitarian actors lack tangible ideas in this domain. Further research and analysis in this area would provide a broader evidentiary basis on which policy could be further developed. Going forward, this may be an area for particularly constructive, pragmatic, research-informed, and detailed dialogue between humanitarian actors, governments, and relevant Security Council bodies.

Relevant U.N. bodies-whether counterterrorism entities (such as the CounterTerrorism Executive Directorate, the Counter-Terrorism Committee, and/or the 1267/1989 Monitoring Group); legal offices (such as the Office of Legal Affairs); and/ or humanitarian entities (such as the Office for the Coordination of Humanitarian Affairs) - should evaluate whether to develop model clauses and framings for use in U.N. documents, resolutions, and the like regarding such exemptions. Those bodies could draw on and learn from previous potentially related examples, such as the limited humanitarian exemption concerning Somalia imposed by the Security Council 
in Resolution 1916 (2010). The main point of model clauses would not be to focus on creating text that would necessarily be exactly replicated but rather to provide examples to governments as to how exemptions and exceptions could be crafted while still complying with binding Council counterterrorism obligations and ensuring that states are not creating loopholes for those who intentionally seek to finance terrorism or abuse the non-profit sector.

\section{Evidence and data related to potential counterterrorism impacts on humanitarian action}

Participate in efforts to document impact by building consensus around what counts as impact and then specifically identifying those impacts over time. There is a relative dearth of publicly available information from humanitarian organizations and research bodies concerning the real or potential impacts of counterterrorism measures on specific instances of principled humanitarian action. Humanitarian organizations may have understandable reasons for not making such claims publicly. But the lack of such specific information may create a distorted view of the actual or perceived impacts of counterterrorism measures on principled humanitarian action. As noted above, Security Council-imposed FTF measures may exacerbate existing tensions-and increase confusion regarding pertinent legal obligations and policies-between state responses to terrorism and principled humanitarian action.

Humanitarian organizations could participate in and spearhead efforts to document impact, to identify criteria for impact, and to agree on what counts as impact (e.g., administrative impact, impact of needing to use funds for vetting and due diligence, other second-order impacts, reputational harm, and, of course, cases of both direct and indirect effects on beneficiaries). Those organizations could also identify ways that they can document impact without putting themselves, their staff, or their partners at risk. Such efforts need not necessarily mean engaging in vocal advocacy. Nor would such efforts necessarily need every organization to name itself and which specific impacts it has experienced. Rather, the most pressing steps would be to devise a way to collect inputs from high-risk areas and to turn those inputs into reliable data that can be used to inform the development of laws and policies, as well as the implementation of operational decisions. This could involve adopting a methodology that would allow organizations to self-report impacts anonymously, and then would allow an outside organization or group of researchers to verify these reports before entering them into a database that would quantify and weigh impacts. The U.N. Office for the Coordination 
of Humanitarian Affairs and the Inter-Agency Standing Committee may be particularly well-suited to help coordinate these efforts. Ultimately, awareness of these concerns and evidence-informed engagement by counterterrorism bodies, humanitarian organizations, states, and civil society actors-along with systematic documentationmay help ensure that all relevant perspectives inform policy at the intersection of counterterrorism agendas and humanitarian action. 


\section{BIBLIOGRAPHY}

Australian Criminal Code, https://www.comlaw.gov.au/Series/C2004A04868.

Australian Government, Control Orders, http://www.ag.gov.au/nationalsecurity/counterterrorismlaw/pages/ controlorders.aspx

Australian Government, Passports Act (2014), http://parlinfo.aph.gov.au/.

Backgrounder, Government of Canada, Seizure of Terrorist Propaganda (Jan. 2015), http://news.gc.ca/web/article.

Backgrounder, Government of Canada, Strengthening Prevention Powers (Jan. 2015), http://news.gc.ca/web/ article-en.do?nid=926009\&_ga=1.257644489.335140496.1436125429.

Bosnia and Herzegovina Criminal Code, Article 162b, Illegal Formation and Joining of Foreign Paramilitary or Para-Police Formations, http://www.coe.int/t/dlapil/codexter/Country\%20Profiles/Legislation/.

Center for Security Studies, Foreign Fighters: A Review of Responses in Eleven Countries, http://www.css.ethz.ch/ publications/pdfs/Foreign_Fighters_2014.pdf.

Committee of Experts on Terrorism (CODEXTER), Profiles on Counter-Terrorism Capacity: Belgium (Feb. 2014), http://www.legislationline.org/topics/country/41/topic/5.

Criminal Law of the People's Republic of China (English) http://www.fmprc.gov.cn/ce/cgvienna/eng/ dbtyw/jdwt/crimelaw/t209043.htm.

Simon Denyer, China's New Terrorism Law Provokes Anger in U.S., Concerns at Home, (March 5, 2015), http://www. washingtonpost.com/world/asia_pacific/china-invokes-terrorism-as-it-readies-additional-harshmeasures/2015/03/04/.

European Commission, Report from the Commission to the European Parliament and the Council on the implementation of Council Framework Decision 2008/919/JHA amending Framework Decision 2002/475/JHA on combating terrorism, (Sept. 5, 2014) http:// ec.europa.eu/dgs/home-affairs/e-library/documents/policies/crisis-and-terrorism/.

German Criminal Code (last amended Sept. 2013), http://www.gesetze-im-internet.de/englisch_stgb/ englisch_stgb.html.

Daniel Hurst, Foreign Fighter Measures Approved as Senate Passes Counter-Terrorism Bill, The Guardian, (Oct. 28, 2014), http:// www.theguardian.com/australia-news/2014/oct/29/foreign-fighter-measures-approved-as-senatepasses-counter-terrorism-bill.

The Guardian, New Zealand Approves Anti-Terrorism Laws to Counter Foreign Fighters Risk (Dec. 9, 2014), http://www. theguardian.com/world/2014/dec/10/new-zealand-approves-anti-terrorism-laws-to-counter-foreignfighters-risk. 
The International Centre for Not-for-Profit Law, NGO Law Monitor, http://www.icnl.org/research/monitor/ index.html.

International Centre for the Study of Radicalisation and Political Violence, Foreign Fighter Total in Syria/Iraq Exceeds 20,000; Surpasses Iraq Conflict in 1980s (January 26, 2015) http://icsr.info/2015/01/foreign-fighter-total-syriairaqnow-exceeds-20000-surpasses-afghanistan-conflict-1980s/.

Kate Mackintosh and Patrick Duplat, Study of the Impact of Donor Counter-Terrorism Measures on Principled Humanitarian Action (2013), https://docs.unocha.org/sites/dms/documents/ct_study_full_report.pdf

Radio Free Europe, Russian Officials Cite IIS Threat'As Justification for Heightened Security (March 30, 2015), http://www.rferl. org/content/islamic-state-russia-heightened-security/26928550.html.

Kent Roach (ed.), Comparative Counter-Terrorism Law (2015).

Terrorism Act 2000 (United Kingdom), http://www.legislation.gov.uk/ukpga/2000/11/contents.

U.S. Department of State, Country Reports on Terrorism (2014), http://www.state.gov/j/ct/rls/crt/2014/ index.htm.

U.S. Library of Congress, Treatment of Foreign Fighters in Selected Jurisdictions: Country Surveys, http://www.loc.gov/law/ help/foreign-fighters/country-surveys.php.

The Washington Institute, U.S. Government Approach to Foreign Terrorist Fighters in Syria and the Broader Region (Feb. 2, 2015), https://www.washingtoninstitute.org/uploads/Documents/other/AlphaStatement20150202.pdf.

The White House, Office of the Secretary, Fact Sheet: Comprehensive U.S. Government Approach to Foreign Terrorist Fighters in Syria and the Broader Region (Sept. 24, 2014), https://www.whitehouse.gov/the-press-office/2014/09/24/fact-sheetcomprehensive-us-government-approach-foreign-terrorist-fighte.

Griff Witte and Souad Mekhennet, Britain Split on How to Counter Draw of Radicalism, Washington Post (July 3, 2015), https://www.washingtonpost.com/world/europe/ten-years-after-77-bombings-britain-is-split-over-howto-fight-extremism/2015/07/03/.

The World Bank, GDP, http://data.worldbank.org/indicator/NY.GDP.MKTP.CD.

David Wroe, Prosecutions of Foreign Fighters Hard, Experts Say as Labor's Matthew Gardiner Returns Home, Sydney Morning Herald (April 7, 2015), http://www.smh.com.au/federal-politics/political-news/prosecutions-of-foreign-fightershard-experts-say-as-labors-matthew-gardiner-returns-home-20150407-1 mfdwm.html. 


\section{APPENDIX: RESEARCH BASES FOR PROVISIONAL QUANTITATIVE ALLOCATION OF POINTS PER STATE}

\section{Australia}

\section{Compliance with five key foreign terrorist fighter elements of Resolution 2178 (2014)}

\section{Points allocated: $\mathbf{4 7}$ out of $\mathbf{5 0}$ (see methodology section).}

Prevent and suppress foreign terrorist fighter travel: 7 out of 10.

Assessment criterion i: 6 out of 8. Criteria ii and iii: 1 out of 2: Australia may subject a person (must be over 16 years old) to a preventative detention order (allowing the authorities to take a person into custody and detain that person for a short period of time to prevent an imminent terrorist attack from occurring or to preserve evidence relating to a recent attack) or issue a control order. A person may be subject to a control order if it substantially helps prevent a terrorist attack, or if the person has trained or participated in training with a listed terrorist organization, engaged in hostile activity in a foreign country, or been previously convicted of a terrorism offense. A control order may prevent a person's freedom of movement by confining the person to a particular area or preventing the person from leaving the country; prevent communication or association with certain people; carrying out certain activities, including work; or accessing certain forms of technology, including the internet. The person may be required to remain at a specified location for a maximum of 12 hours. Control orders must be issued by a court and must have the consent of the Attorney General (http://www.ag.gov. au/nationalsecurity/counterterrorismlaw/pages/controlorders.aspx). In October 2014, Australian lawmakers adopted amendments to the Australian Passports Act, which allow for the suspension of a person's Australian travel documents for 14 days if requested by the Director-General of Security. The law also allows a person's passport to be canceled if it is suspected that the person is likely to engage in conduct that might prejudice the security of Australia (http://www.loc.gov/law/help/foreign-fighters/ country-surveys.php). See also http://parlinfo.aph.gov.au/ for text of bill (Section 22A). 
Penalizing foreign terrorist fighter conduct: 10 out of 10 (see methodology section).

Australia adopted amendments to its Criminal Code in October 2014 that criminalize "advocating terrorism" (punishable by five years' imprisonment) and entering or remaining in a "declared area" of a foreign country where a terrorist organization is engaging in hostile activity (punishable by ten years' imprisonment) (http://www.loc.gov/law/help/foreign-fighters/country-surveys.php; see also http:// www.theguardian.com/australia-news/2014/oct/29/foreign-fighter-measures-approved-as-senatepasses-counter-terrorism-bill). The amendments also permit the use of "delayed notification search warrants." Providing or receiving terrorist training in Australia or abroad is punishable by up to 25 years' imprisonment (Australian Criminal Code, Art. 101.2 and 102.5, https://www.comlaw.gov.au/Details/ C2015C00254). Preparation for or planning a terrorist act is punishable by life imprisonment (Art. 101.6).

\section{Penalize funding to foreign terrorist fighters: 10 out of 10 (see methodology section).}

If a person receives funds from or makes funds available to a terrorist organization, or collects funds for a terrorist organization, they may be punished with up to 25 years' imprisonment (Art. 102.6). Providing support or resources to terrorist groups is also punishable by up to 25 years' imprisonment (Art. 102.7). If a person provides or collects funds and is reckless as to whether the funds will be used to facilitate or engage in a terrorist act, if convicted, they would receive life imprisonment (Art. 103.1). Australia has continued to play an active role in regional organizations, such as ASEAN, the ASEAN Regional Forum, and the Pacific Island Forum (http://www.state.gov/documents/organization/239631.pdf).

Penalize the facilitation of (including organization and recruitment of) foreign terrorist fighters: 10 out of 10 (see methodology section).

Recruitment for a terrorist organization is punishable by a maximum of 25 years' imprisonment (Art. 102.4, Australian Criminal Code).

Bring foreign terrorist fighters to "justice": 10 out of 10 (see methodology section).

Recent news articles have focused on the evidentiary hurdles that prosecutors face in successfully charging and convicting returned foreign fighters (http://www.smh.com.au/federal-politics/politicalnews/prosecutions-of-foreign-fighters-hard-experts-say-as-labors-matthew-gardiner-returns-home20150407-1 mfdwm.html). See also http://www.nytimes.com/2015/07/26/world/asia/australia-arrestsnurse-who-says-he-worked-with-isis-under-duress.html.

\section{Support of five key aspects of principled humanitarian action in counterterrorism contexts}

\section{Points allocated: $\mathbf{4 6}$ out of $\mathbf{5 0}$ (see methodology section).}

Knowability of anti-terrorism lists: 10 out of 10 (see methodology section).

Australia maintains a publicly available terrorist list (http://www.nationalsecurity.gov.au/ Listedterroristorganisations/Pages/default.aspx). 
Ease of navigability and efficiency of the regulatory system: 10 out of 10 (see methodology section).

Initial research suggests that the relevant portions of the regulatory system are relatively easy to navigate and efficient. (But note that the FATF found that Australia was noncompliant with Recommendation 8) (http://www.fatf-gafi.org/media/fatf/documents/reports/mer4/Mutual-EvaluationReport-Australia-2015.pdf).

Explicit exemptions from counterterrorism measures of principled humanitarian action: 10 out of 10 (see methodology section).

See Australian Criminal Code, Section 119.4(7) (providing that the section on the crime of preparations for incursions into foreign countries for purpose of engaging in hostile activities "does not apply if the person engages in conduct solely by way of, or for the purposes of, the provision of aid of a humanitarian nature.") See also Section 102.8(4)(c), providing that the section on the crime of associating with terrorist organizations "does not apply if: [...] the association is only for the purpose of providing aid of a humanitarian nature"), Section 119.2(3)(a) (providing that the section on the crime of entering, or remaining in, declared areas "does not apply if the person enters, or remains in, the area solely for one or more of the following purposes: providing aid of a humanitarian nature"), and Section 119.5(4) (providing that the section on the crime of allowing the use of buildings, vessels and aircraft to commit offences "does not apply if the person engages in conduct solely by way of, or for the purposes of, the provision of aid of a humanitarian nature.")

No reported legal proceedings on the basis of principled humanitarian action in conflict zones involving terrorists nor reported "chilling effect" (self-imposed curtailment) of principled humanitarian action due to state counterterrorism measures: 10 out of 10 (see methodology section).

Initial research did not uncover evidence that the state has instituted criminal or civil counterterrorism proceedings on the basis of engaging in principled humanitarian action in conflict zones involving terrorists. In one (potentially) related case, it is not clear whether the institution of legal proceedings was based on martial support (even if under duress) to designated terrorists, rather than on provision of humanitarian aid and assistance to designated terrorists (see http://www.nytimes.com/2015/07/26/ world/asia/australia-arrests-nurse-who-says-he-worked-with-isis-under-duress.html). Initial research did not uncover evidence that the state's domestic counterterrorism legislation had or has a reported "chilling effect" on principled humanitarian organizations.

Financial support via designated channel to Iraq and Syria in 2015 (to date) as a percentage of GDP: 6 out of 10 (see methodology section).

0.002\% (http://data.worldbank.org/indicator/NY.GDP.MKTP.CD and https://fts.unocha.org/pageloader. aspx?page=search-customsearch).

\section{BELGIUM}

\section{Compliance with five key foreign terrorist fighter elements of Resolution 2178 (2014)}

\section{Points allocated: 43 out of 50 (see methodology section).}


Preventing and suppressing foreign terrorist fighter travel: 3 out of 10 (see methodology section).

Assessment criterion i: 2 out of 8. Assessment criteria ii and iii: 1 out of 2: A 1979 law prohibits the recruitment of Belgian citizens by foreign armed forces and authorizes the government (requiring a government decree) to prohibit Belgian citizens from joining foreign armed forces. The punishment for this crime ranges from three months' to two years' imprisonment. Article 140 of the Belgian Penal Code also prohibits recruitment to commit a terrorist crime (http://www.css.ethz.ch/publications/pdfs/ Foreign_Fighters_2014.pdf). The new coalition government, elected in 2014, has applied prohibitions to Belgian citizens who participate in foreign conflicts such as Syria, and has increased the sanctions under the law, to include the option of courts to strip dual citizens of their Belgian citizenship (http:// www.state.gov/j/ct/rls/crt/2014/239406.htm). Twelve such measures were announced on January 16, 2015 (http://www.premier.be/sites/default/files/articles/PPT_16012015_définitif.pdf)."Belgian officials announced stricter enforcement of regulations that allow them to prohibit passport issuance of or revocation of passports to disrupt the travel of suspected foreign terrorist fighters. All new Belgian passports include biometric data" (http://www.state.gov/j/ct/rls/crt/2014/239406.htm).

Penalizing foreign terrorist fighter conduct: 10 out of 10 (see methodology section).

Belgian counterterrorism law includes provisions that could be applied to foreign fighters, including provisions of the Belgian Penal Code (Article 140) prohibiting actions that constitute "take part in the activities of a terrorist group... with the true knowledge that this participation contributes to the perpetration of a crime or an offense by the terrorist group." Article 140 also criminalizes "any person who, in Belgium or abroad, receives [terrorist training]" (http://www.css.ethz.ch/publications/pdfs/ Foreign_Fighters_2014.pdf). Penalties for these acts can range from five to ten years' imprisonment and a fine of 100 to 5,000 euros (http://www.legislationline.org/topics/country/41/topic/5).

Penalize funding to foreign terrorist fighters: 10 out of 10 (see methodology section).

Article 140 of the Belgian Penal Code also criminalizes the following: "anyone who participates in an activity of a terrorist group, including by providing it with information or material resources or through any form of financing of a terrorist group's activity, in the knowledge that such participation aides the commission of a crime or offense." (http://www.legislationline.org/topics/country/41/topic/5). Belgium is a member of the FATF, the Egmont Group, and MONEYVAL, a FATF-style regional body. It also employs a financial intelligence unit to track and investigate financial crimes such as terrorist financing (http://www.state.gov/j/ct/rls/crt/2014/239406.htm).

Penalize the facilitation of (including organization and recruitment of) foreign terrorist fighters: 10 out of 10 (see methodology section).

Belgian counterterrorism law includes provisions that could be applied to foreign fighters, including provisions of the Belgian Penal Code (Article 140) prohibiting actions that constitute "tak[ing] part in the activities of a terrorist group... with the true knowledge that this participation contributes to the perpetration of a crime or an offense by the terrorist group." (http://www.css.ethz.ch/publications/pdfs/ Foreign_Fighters_2014.pdf). Penalties for these acts can range from five to ten years' imprisonment and a fine of 100 to 5,000 euros (http://www.legislationline.org/topics/country/41/topic/5).

Bring foreign terrorist fighters to "justice": 10 out of 10 (see methodology section).

Of the estimated 358 foreign terrorist fighters of Belgian origin, approximately 87 have returned 
to Belgium (http://www.state.gov/j/ct/rls/crt/2014/239406.htm). Measures taken toward these individuals include monitoring upon return from fighting abroad; measures aimed at reintegration; and deleting individuals from local residents' registries, thereby denying them some public benefits (http://www.css.ethz.ch/publications/pdfs/Foreign_Fighters_2014.pdf). The Belgian Penal Code allows for extraterritorial jurisdiction over terrorist acts (http://www.legislationline.org/topics/country/41/ topic/5). A French-Algerian dual national (and alleged former FTFer) was arrested by authorities and extradited to Belgium for shooting and killing four individuals at the Brussels Jewish Museum. Others have been prosecuted for alleged participation in terrorist activities abroad (http://www.state.gov/j/ct/ rls/crt/2014/239406.htm).

\section{Support of five key aspects of principled humanitarian action in counterterrorism contexts}

\section{Points allocated: $\mathbf{3 6}$ out of $\mathbf{5 0}$ (see methodology section).}

Knowability of anti-terrorism lists: 10 out of 10 (see methodology section).

While Belgium does not maintain a domestic terrorist list, the country belongs to the European Union, which does maintain publicly available terrorist lists that comply with the provisions of the al-Qaeda sanctions and other relevant Security Council measures (http://www.consilium.europa.eu/en/policies/ fight-against-terrorism/terrorist-list/).

Ease of navigability and efficiency of the regulatory system: 10 out of 10 (see methodology section).

Initial research suggests that the relevant portions of the regulatory system are relatively easy to navigate and efficient. Belgium nonprofit associations are subject to the same accounting rules as commercial enterprises and smaller organizations face simplified accounting rules (http://www.fatfgafi.org/media/fatf/documents/reports/mer4/Mutual-Evaluation-Report-Belgium-2015.pdf). Larger nonprofit organizations must submit information regarding the purpose and objectives of their activities, as well as the identities of their senior leadership and board members.

Explicit exemptions from counterterrorism measures of principled humanitarian action: 0 out of 10 (see methodology section).

Initial research suggests that the domestic legislation, if any, limiting travel to conflict zones involving terrorists does not exempt staff of principled humanitarian organizations (expressly or as a subset of non-profit organizations, automatically or potentially through a petition/license); that domestic legislation, if any, applicable within the territory of the state and/or extraterritorially restricting engagement with terrorists does not exempt impartial wartime medical care for terrorists; and that relevant domestic legislation, if any, does not exempt other forms of principled humanitarian action in conflict zones involving terrorists.

No reported legal proceedings on the basis of principled humanitarian action in conflict zones involving terrorists nor reported "chilling effect" (self-imposed curtailment) of principled humanitarian action due to state counterterrorism measures: 10 out of 10 (see methodology section).

Initial research did not uncover evidence that the state has instituted criminal or civil counterterrorism 
proceedings on the basis of engaging in principled humanitarian action in conflict zones involving terrorists. Nor did initial research uncover evidence that the state's domestic counterterrorism legislation had or has a reported "chilling effect" on principled humanitarian organizations.

Financial support via designated channel to Iraq and Syria in 2015 (to date) as a percentage of GDP: 6 out of 10 (see methodology section).

0.00398\% (http://data.worldbank.org/indicator/NY.GDP.MKTP.CD and https://fts.unocha.org/ pageloader.aspx?page=search-customsearch).

\section{Bosnia ANd HeRzegovina}

\section{Compliance with five key foreign terrorist fighter elements of Resolution 2178 (2014)}

\section{Points allocated: 29 out of $\mathbf{5 0}$ (see methodology section).}

Preventing and suppressing foreign terrorist fighter travel: 1 out of 10 (see methodology section).

Assessment criterion i: 0 out of 8. Assessment criteria ii and iii: 1 out of 2: In April 2014, the legislature adopted amendments to the Criminal Code (Article 162b) that extend prison terms for convicted terrorists to ten years. The amendments also include a five-year minimum sentence to anyone who "organizes, directs, trains, equips, or mobilizes individuals or groups for the purpose of joining, in any manner, foreign military or foreign para-police formations that operate outside of Bosnia and Herzegovina, shall be punished by imprisonment for a term not less than five years." Those individuals who "join in any way a foreign paramilitary and para-police formation" face a minimum three-year sentence. Recruitment, as well as "anyone who procures or makes available means, removes obstacles, creates plans, or makes agreements with others...or undertakes any activity that creates the conditions for directly committing this criminal offense" is punishable by one to ten years' imprisonment (http:// www.coe.int/t/dlapil/codexter/Country\%20Profiles/Legislation/BiH\%20Criminal\%20Code $\% 20$ Article\%20162b\%20-\%20draft.pdf). "The Bosnia Border Police uses a computerized database and software system to support immigration and passenger information collection. The system links all 55 border crossings and four airport locations via the State Police Information Network, which provides the Border Police with immediate access to other databases (including Interpol) to run appropriate checks and cross-checks. Derogatory information triggers a 'hit' when a subject's passport or identification card is passed through the scanner at the port of entry. Individuals may be detained for up to 24 hours while Border Police officials consult with other agencies about next steps" (http://www. state.gov/j/ct/rls/crt/2014/239406.htm).

\section{Penalizing foreign terrorist fighter conduct: 2 out of 10 (see methodology section).}

In April 2014, the legislature adopted amendments to the Criminal Code that extend prison terms for convicted terrorists to ten years (http://www.loc.gov/law/help/foreign-fighters/country-surveys. php\#Bosnia\%20and\%20Herzegovina). 
Penalize funding to foreign terrorist fighters: 6 out of 10 (see methodology section).

Bosnia belongs to the Egmont Group and to MONEYVAL, a regional FATF-style body, which expressed concerns in 2014 that Bosnia needed to improve its laws to better deter and detect terrorist financing. Bosnia's new law on the Prevention of Money Laundering and Terrorism Financing had not been fully implemented by the end of 2014 (http://www.state.gov/j/ct/rls/crt/2014/239406.htm).

Penalize the facilitation of (including organization and recruitment of) foreign terrorist fighters: 10 out of 10 (see methodology section).

Recruitment, as well as "anyone who procures or makes available means, removes obstacles, creates plans, or makes agreements with others....or undertakes any activity that creates the conditions for directly committing this criminal offense" is punishable by one to ten years' imprisonment (http://www. coe.int/t/dlapil/codexter/Country\%20Profiles/Legislation/BiH\%20Criminal\%20Code\%20Article\%20 $162 \mathrm{~b} \% 20-\% 20 d r a f t . p d f)$.

Bring foreign terrorist fighters to "justice": 10 out of 10 (see methodology section).

In September 2014, the State Court of Bosnia and Herzegovina ordered a one-month sentence for five individuals found guilty of recruiting people to join fighters in Syria and Iraq (http://www.loc.gov/law/ help/foreign-fighters/country-surveys.php\#Bosnia\%20and\%20Herzegovina).

\section{Support of five key aspects of principled humanitarian action in counterterrorism contexts}

\section{Points allocated: 22 out of 50 (see methodology section).}

Knowability of anti-terrorism lists: 0 out of 10 (see methodology section).

Initial research did not uncover evidence that the state has established a domestic anti-terrorism list (at a minimum, a list implementing binding Security Council-imposed al-Qaeda-related sanctions) and/or made the requisite measures relating to that list publicly available.

Ease of navigability and efficiency of the regulatory system: 10 out of 10 (see methodology section).

Initial research suggests that the relevant portions of the regulatory system are relatively easy to navigate and efficient. Nonprofit organizations must register with the government, but there appears to be no other special requirements specifically aimed at NGOs (http://www.coe.int/t/dghl/monitoring/ moneyval/Evaluations/round3/MONEYVAL(2009)42Rep_BIH3_en.pdf).

Explicit exemptions from counterterrorism measures of principled humanitarian action: 0 out of 10 (see methodology section).

Initial research suggests that the domestic legislation, if any, limiting travel to conflict zones involving terrorists does not exempt staff of principled humanitarian organizations (expressly or as a subset of non-profit organizations, automatically or potentially through a petition/license); that domestic legislation, if any, applicable within the territory of the state and/or extraterritorially restricting engagement with terrorists does not exempt impartial wartime medical care for terrorists; and that 
relevant domestic legislation, if any, does not exempt other forms of principled humanitarian action in conflict zones involving terrorists.

No reported legal proceedings on the basis of principled humanitarian action in conflict zones involving terrorists nor reported "chilling effect" (self-imposed curtailment) of principled humanitarian action due to state counterterrorism measures: 10 out of 10 (see methodology section).

Initial research did not uncover evidence that the state has instituted criminal or civil counterterrorism proceedings on the basis of engaging in principled humanitarian action in conflict zones involving terrorists. Nor did initial research uncover evidence that the state's domestic counterterrorism legislation had or has a reported "chilling effect" on principled humanitarian organizations.

Financial support via designated channel to Iraq and Syria in 2015 (to date) as a percentage of GDP: 2 out of 10 (see methodology section).

$0 \%$ (no financial assistance reportedly provided via the designated funding channel) (http://data. worldbank.org/indicator/NY.GDP.MKTP.CD and https://fts.unocha.org/pageloader.aspx?page=searchcustomsearch).

\section{CANADA}

\section{Compliance with five key foreign terrorist fighter elements of Resolution 2178 (2014)}

\section{Points allocated: $\mathbf{4 8}$ out of $\mathbf{5 0}$ (see methodology section).}

Preventing and suppressing foreign terrorist fighter travel: 8 out of 10 (see methodology section).

Assessment criterion i: 6 out of 8. Assessment criteria ii and iii: 2 out of 2: In 2013, Canada's Criminal Code was amended by the Combating Terrorism Act to make it a criminal offense for individuals to leave the country for the purpose of participating in the activity of a terrorist group, punishable by up to ten years' imprisonment (http://www.loc.gov/law/help/foreign-fighters/country-surveys. php). In June 2015, Canada passed its Anti-Terrorism Act 2015, which aims to prevent terrorists from recruiting others by allowing government officials to seize terrorist propaganda, including from the Internet (http://news.gc.ca/web/article-en.do?nid=926039\&_ga=1.55138409.335140496.1436125429) . "The Passenger Protect Program identifies individuals who may pose a threat to aviation security and reduces their ability to harm or threaten aviation by taking preventative action, such as not allowing them to board an aircraft" (http://www.state.gov/documents/organization/239631.pdf). Additionally, the 2015 Anti-Terrorism Act "enhance[s] the ability of law enforcement agencies to detain suspected terrorists before they can harm Canadians...while still requiring judicial authorization of the detention either before or after the arrest" (http://news.gc.ca/web/article-en.do?nid=926009\&_ga=1.257644489 .335140496.1436125429). “Canadian officials can deny passport applications or revoke valid passports of Canadian citizens suspected of traveling abroad (or aspiring to travel abroad) to commit acts of terrorism. In June 2014, the government passed the Strengthening Canadian Citizenship Act (C-24), which provides for the collection, retention, use, disclosure, and disposal of information on Canadian 
citizens, including disclosure for the purposes of national security, the defense of Canada, the conduct of international affairs, or the verification of citizenship status or identity of any person for the purpose of administering the law of another country. C-24 also permitted the Canadian government to strip Canadian citizenship from dual nationals convicted of treason, terrorism, and espionage. Canada has an extensive border security network and uses travel document security technology, biographic and biometric screening capabilities at ports of entry, information sharing with host governments and other countries, and collection of advance passenger name record information on commercial flights" (http://www.state.gov/documents/organization/239631.pdf).

Penalizing foreign terrorist fighter conduct: 10 out of 10 (see methodology section).

Committing terrorist acts, conspiring to commit terrorist acts, and traveling abroad to commit acts of terrorism violates Canadian law (http://www.state.gov/documents/organization/239631.pdf).

Penalize funding to foreign terrorist fighters: 10 out of 10 (see methodology section).

Canada is a member of the FATF and the Asia/Pacific Group on Money Laundering. It has a "rigorous detection and monitoring process in place to identify money laundering and terrorist financing activities." In June 2014, the Canadian government adopted the Economic Action Plan 2014 (C-31), which, among other things, enhanced recordkeeping and registration requirements for financial institutions and intermediaries (http://www.state.gov/documents/organization/239631.pdf). “Canada works closely with the United States on bilateral homeland security programs such as the Beyond the Border initiative and the Cross Border Crime Forum. It has also contributed to the Global Coalition to Counter ISIL. In June 2014, the government passed the Strengthening Canadian Citizenship Act (C-24), which provides for the collection, retention, use, disclosure, and disposal of information on Canadian citizens, including disclosure for the purposes of national security, the defense of Canada, the conduct of international affairs, or the verification of citizenship status or identity of any person for the purpose of administering the law of another country. In December 2014, Canada lawmakers passed the Protecting Canadians from Online Crime Act (C-13), which, among other things, allows for cooperation amongst specific states by establishing a system for exchanging information and evidence on behalf of a foreign state for use in a criminal investigation and prosecution conducted by that state" (http:// www.state.gov/documents/organization/239631.pdf).

Penalize the facilitation of (including organization and recruitment of) foreign terrorist fighters: 10 out of 10 (see methodology section).

In 2013, Canada's Criminal Code was amended by the Combating Terrorism Act to make it a criminal offense for individuals to leave the country for the purpose of participating in the activity of a terrorist group, punishable by up to ten years' imprisonment (http://www.loc.gov/law/help/foreign-fighters/ country-surveys.php). In June 2015, Canada passed its Anti-Terrorism Act 2015, which aims to prevent terrorists from recruiting others by allowing government officials to seize terrorist propaganda, including from the Internet (http://news.gc.ca/web/article-en.do?nid=926039\&_ga=1.55138409.33514 0496.1436125429).

Bring foreign terrorist fighters to "justice": 10 out of 10 (see methodology section).

"In July 2014, Canadian authorities handed down the first charge for travel for the purposes of terrorism. A Canadian national was charged in absentia for murder 'in association with a terrorist group,' reportedly in Syria" (http://www.state.gov/documents/organization/239631.pdf). 


\section{Support of five key aspects of principled humanitarian action in counterterrorism contexts}

\section{Points allocated: $\mathbf{4 2}$ out of $\mathbf{5 0}$ (see methodology section).}

Knowability of anti-terrorism lists: 10 out of 10 (see methodology section).

Canada maintains a publicly available terrorist list (http://www.publicsafety.gc.ca/cnt/ntnl-scrt/cntrtrrrsm/lstd-ntts/index-eng.aspx).

Ease of navigability and efficiency of the regulatory system: 10 out of 10 (see methodology section).

Initial research suggests that the relevant portions of the regulatory system are relatively easy to navigate and efficient. The Charities Registration Act makes it possible for government officials to issue security certificates against a charity based on intelligence, which can prevent an organization from registering or deregisters an existing charity (http://www.researchgate.net/publication/225923254_ International_NGOs_and_National_Regulation_in_an_Age_of_Terrorism). See also http://www.cra-arc. gc.ca/chrts-gvng/chrts/chcklsts/vtb-eng.html (Checklist for Charities on Avoiding Terrorist Abuse). This Act, however, does not appear to impose especially onerous restrictions on non-profit organizations with respect to funding, registration, and/or financial reporting. Initial research suggests that domestic legislation prohibiting financial transactions with terrorists appears to exempt principled humanitarian organizations (expressly or as a subset of non-profit organizations, whether automatically or through a petition or license) (https://docs.unocha.org/sites/dms/documents/ct_study_full_report.pdf).

Explicit exemptions from counterterrorism measures of principled humanitarian action: 7 out of 10 (see methodology section).

The Criminal Code, Section 83.01(1) provides that the definition of "terrorist activity" expressly "does not include an act or omission that is committed during an armed conflict and that, at the time and in the place of its commission, is in accordance with customary international law or conventional international law applicable to the conflict, or the activities undertaken by military forces of a state in the exercise of their official duties, to the extent that those activities are governed by other rules of international law." Thus, this section exempts only those elements of principled humanitarian action undertaken in accordance with customary international law or conventional international law applicable to armed conflict.

No reported self-imposed curtailment ("chilling effect") of principled humanitarian action due to state counterterrorism measures: 5 out of 10 (see methodology section).

Initial research did not uncover evidence that the state has instituted criminal or civil counterterrorism proceedings on the basis of engaging in principled humanitarian action in conflict zones involving terrorists. "Some humanitarian actors reported that counter-terrorism legislation in countries such as Canada... as well as restrictions in funding agreements, had a 'chilling effect."' (https://docs.unocha.org/ sites/dms/documents/ct_study_full_report.pdf).

Financial support via designated channel to Iraq and Syria in 2015 (to date) as a percentage of GDP: 10 out of 10 (see methodology section).

0.00967\% (http://data.worldbank.org/indicator/NY.GDP.MKTP.CD and https://fts.unocha.org/ pageloader.aspx?page=search-customsearch). 


\section{ChINA}

\section{Compliance with five key foreign terrorist fighter elements of Resolution 2178 (2014)}

\section{Points allocated: 24 out of 50 (see methodology section).}

Preventing and suppressing foreign terrorist fighter travel: 8 out of 10 (see methodology section).

Assessment criterion i: 8 out of 8. Assessment criteria ii and iii: 0 out of 2: Initial research did not uncover evidence that the state prevents entry or transit through their territory of FTFs, nor did our research uncover evidence that the state prevents the movement of terrorists or terrorist groups by effective border controls and controls on issuance of identity papers and travel documents (see methodology section).

Penalizing foreign terrorist fighter conduct: 2 out of 10 (see methodology section).

In 2014, China began consideration of a draft counterterrorism law, which has been subject to criticism by certain governments and activists for being too restrictive of and violating individual rights. On an initial review, the draft law, in defining terrorism broadly to include not only "activity" but also "opinion" that "generates social panic, threatens public security, or coerces a state organ or international organization," nonetheless does not appear to fully penalize all of the relevant Security Councilimposed obligations concerning FTF conduct (http://www.washingtonpost.com/world/asia_pacific/ china-invokes-terrorism-as-it-readies-additional-harsh-measures/2015/03/04/html).

\section{Penalize funding to foreign terrorist fighters: 6 out of 10 (see methodology section).}

China is a member of the FATF and two other FATF-style regional bodies. The government has strengthened its preventative measures to combat terrorist financing, emphasizing that financial institutions are required to collect and maintain beneficial ownership information, and making Suspicious Transaction Reports more comprehensive (http://www.state.gov/documents/ organization/239631.pdf). Its draft counterterrorism law includes a section mandating that the central bank and civil administration should supervise and inspect financial flows into foundations, social organizations, and foreign NGOs (http://www.washingtonpost.com/world/asia_pacific/chinainvokes-terrorism-as-it-readies-additional-harsh-measures/2015/03/04/1e078288-139c-497e-aa8ae6d810a5a8a2_story.html).

Penalize the facilitation of (including organization and recruitment of) foreign terrorist fighters: 6 out of 10 (see methodology section).

Under Article 120 of China's Criminal Code, anyone who "organizes, leads, and actively participates in a terrorist organization" will receive three to ten years' imprisonment, or "criminal detention if circumstances are relatively minor." (http://www.fmprc.gov.cn/ce/cgvienna/eng/dbtyw/jdwt/crimelaw/ t209043.htm). Thus, on an initial review, the state's legislation does not appear to criminalize the provision or receiving of terrorist training. 
Bring foreign terrorist fighters to "justice": 2 out of 10 (see methodology section).

Initial research did not uncover evidence that the state has ensured that any person who participates in the financing, planning, preparation, or perpetration of terrorist acts or in supporting terrorist acts is brought to justice.

\section{Support of five key aspects of principled humanitarian action in counterterrorism contexts}

\section{Points allocated: 17 out of $\mathbf{5 0}$ (see methodology section).}

Knowability of anti-terrorism lists: 5 out of 10 (see methodology section).

Initial research uncovered inconclusive evidence as to whether China may maintain a domestic terrorist list (see article at http://www.china-embassy.org/eng/xw/t56257.htm, describing a 2003 listing of Turkish groups identified as terrorist organizations), but our research proved inconclusive on whether China continues to maintain such a list, and if so, who might be listed.

Ease of navigability and efficiency of the regulatory system: 0 out of 10 (see methodology section). Initial evidence suggests the relevant portions of the regulatory system are relatively difficult to navigate and/or inefficient (http://www.icnl.org/research/monitor/china.html).

Explicit exemptions from counterterrorism measures of principled humanitarian action: 0 out of 10 (see methodology section).

Initial research suggests that the domestic legislation, if any, limiting travel to conflict zones involving terrorists does not exempt staff of principled humanitarian organizations (expressly or as a subset of non-profit organizations, automatically or potentially through a petition/license); that domestic legislation, if any, applicable within the territory of the state and/or extraterritorially restricting engagement with terrorists does not exempt impartial wartime medical care for terrorists; and that relevant domestic legislation, if any, does not exempt other forms of principled humanitarian action in conflict zones involving terrorists.

No reported legal proceedings on the basis of principled humanitarian action in conflict zones involving terrorists nor reported "chilling effect" (self-imposed curtailment) of principled humanitarian action due to state counterterrorism measures: 10 out of 10 (see methodology section).

Initial research did not uncover evidence that the state has instituted criminal or civil counterterrorism proceedings on the basis of engaging in principled humanitarian action in conflict zones involving terrorists. Nor did initial research uncover evidence that the state's domestic counterterrorism legislation had or has a reported "chilling effect" on principled humanitarian organizations.

Financial support via designated channel to Iraq and Syria in 2015 (to date) as a percentage of GDP: 2 out of 10 (see methodology section).

0\% (no financial assistance reportedly provided via the designated funding channel) (http://data. worldbank.org/indicator/NY.GDP.MKTP.CD and https://fts.unocha.org/pageloader.aspx?page=searchcustomsearch). 


\section{DenMark}

\section{Compliance with five key foreign terrorist fighter elements of Resolution 2178 (2014)}

\section{Points allocated: $\mathbf{4 3}$ out of $\mathbf{5 0}$ (see methodology section).}

Preventing and suppressing foreign terrorist fighter travel: 3 out of 10 (see methodology section).

Assessment criterion i: 2 out of 8. Assessment criteria ii and iii: 1 out of 2: Under counterterrorism legislation passed in 2006, Denmark can surveil and wiretap terrorist suspects with a valid warrant and sufficient evidentiary proof (http://www.state.gov/j/ct/rls/crt/2014/239406.htm). Chapter 13 of the Danish Penal Code prohibits individuals from participating in unlawful military organizations (http://www.loc.gov/law/help/foreign-fighters/country-surveys.php). Any person who recruits another person to commit or "advance" actions under this section of the Penal Code, including joining a group or association, is subject to ten to sixteen years' imprisonment (Danish Penal Code, Chapter 13, Section 114(c)(1)). Any individual who recruits another person to provide financial support or provide funds to terrorism may be punished for up to six years' imprisonment (Danish Penal Code, Chapter 13, Section 114(c)(2). “Denmark conducts travel document checks for non-Schengen area travel; has biographic and biometric screening capabilities at ports of entry; and security forces patrol and control Denmark's land and sea borders. Denmark has open borders with EU neighbors, pursuant to the Schengen Agreement, and consequently there are no passport controls at the land borders or airport terminals servicing most Schengen Visa area flights" (http://www.state.gov/j/ct/rls/crt/2014/239406. $\mathrm{htm})$. Denmark can confiscate the passports of minors and does not issue new ones unless the minor's parents agree (http://www.css.ethz.ch/publications/pdfs/Foreign_Fighters_2014.pdf).

Penalizing foreign terrorist fighter conduct: 10 out of 10 (see methodology section).

Chapter 13 of the Danish Penal Code criminalizes participation in unlawful military organizations, and instructing others to commit terrorism (http://www.loc.gov/law/help/foreign-fighters/country-surveys. php). Individuals who participate in an illegal military organization or group may receive a fine or up to two years' imprisonment (source: Danish Penal Code, Chapter 13, Section 114(g)). Persons who conduct terrorist training may be imprisoned for up to ten years, while those who train persons on terrorist financing may receive up to six years' imprisonment. Persons who receive terrorist training may be punished with up to six years' imprisonment (Danish Penal Code, Chapter 13, Section 114(d)).

\section{Penalize funding to foreign terrorist fighters: 10 out of 10 (see methodology section).}

Denmark can freeze assets within hours or days with a valid court order. Denmark is also a member of the FATF and the Egmont Group, and it cooperates closely with other Nordic financial intelligence units (source: http://www.state.gov/j/ct/rls/crt/2014/239406.htm). Chapter 13 of the Danish Penal Code criminalizes the financing of terrorism, which is punishable by up to ten years' imprisonment (Danish Penal Code, Chapter 13, Section 114(b)). Persons committing acts under Chapter 13 may lose their Danish citizenship (provided they do not subsequently become stateless) (source: http://www.loc.gov/ law/help/foreign-fighters/country-surveys.php). 
Penalize the facilitation of (including organization and recruitment of) foreign terrorist fighters: 10 out of 10 (see methodology section).

Chapter 13 of the Danish Penal Code prohibits individuals from participating in unlawful military organizations (http://www.loc.gov/law/help/foreign-fighters/country-surveys.php). Any person who recruits another person to commit or "advance" actions under this section of the Penal Code, including to join a group or association, is subject to ten to sixteen years' imprisonment (Danish Penal Code, Chapter 13, Section 114(c)(1)). One report notes, however, that as of February 2014, no criminal case has been brought against an "aspiring foreign fighter" before their departure (http://www.css.ethz.ch/ publications/pdfs/Foreign_Fighters_2014.pdf).

Bring foreign terrorist fighters to "justice": 10 out of 10 (see methodology section).

"Denmark has prosecuted multiple individuals for terrorist acts, including promoting terrorist propaganda (four years' imprisonment); collecting and sending funds to terrorist organizations (case still underway); inciting terrorism by posting a link to his Facebook page to a video of an ISIS spokesperson in Syria (case still underway); and 'explicitly expressing support for terrorism' by posting on Facebook pictures from the Syrian conflict (charged in absentia)" (http://www.state.gov/j/ct/rls/ crt/2014/239406.htm).

\section{Support of five key aspects of principled humanitarian action in counterterrorism contexts}

\section{Points allocated: 35 out of $\mathbf{5 0}$ (see methodology section).}

Knowability of anti-terrorism lists: 10 out of 10 (see methodology section).

While Denmark does not appear to maintain a domestic terrorist list, the country belongs to the European Union, which does maintain publicly available terrorist lists that encompass the provisions of the al-Qaeda sanctions and other relevant Security Council measures (http://www.consilium.europa. eu/en/policies/fight-against-terrorism/terrorist-list/).

Ease of navigability and efficiency of the regulatory system: 10 out of 10 (see methodology section).

Initial research suggests that the relevant portions of the regulatory system are relatively easy to navigate and efficient.

Explicit exemptions from counterterrorism measures of principled humanitarian action: 0 out of 10 (see methodology section).

Initial research suggests that the domestic legislation, if any, limiting travel to conflict zones involving terrorists does not exempt staff of principled humanitarian organizations (expressly or as a subset of non-profit organizations, automatically or potentially through a petition/license); that domestic legislation, if any, applicable within the territory of the state and/or extraterritorially restricting engagement with terrorists does not exempt impartial wartime medical care for terrorists; and that relevant domestic legislation, if any, does not exempt other forms of principled humanitarian action in conflict zones involving terrorists. 
No reported self-imposed curtailment ("chilling effect") of principled humanitarian action due to state counterterrorism measures: 5 out of 10 (see methodology section).

Initial research did not uncover evidence that the state has instituted criminal or civil counterterrorism proceedings on the basis of engaging in principled humanitarian action in conflict zones involving terrorists. However, "[s]ome humanitarian actors reported that counter-terrorism legislation in countries such as ...Denmark... as well as restrictions in funding agreements, had a 'chilling effect."' (https://docs.unocha.org/sites/dms/documents/ct_study_full_report.pdf).

Financial support via designated channel to Iraq and Syria in 2015 (to date) as a percentage of GDP: 10 out of 10 (see methodology section).

0.00722\% (http://data.worldbank.org/indicator/NY.GDP.MKTP.CD and https://fts.unocha.org/ pageloader.aspx?page=search-customsearch).

\section{France}

\section{Compliance with five key foreign terrorist fighter elements of Resolution 2178 (2014)}

\section{Points allocated: $\mathbf{4 6}$ out of $\mathbf{5 0}$ (see methodology section).}

Preventing and suppressing foreign terrorist fighter travel: 6 out of 10 (see methodology section).

Assessment criterion i: 4 out of 8. Assessment criteria ii and iii: 2 out of 2: Under a 2012 counterterrorism law (Law No. 2012-1431 of December 21, 2012, Regarding Security and the Fight Against Terrorism), French criminal law (including provisions regarding participation in a group formed for the purpose of preparing an act of terrorism) should apply to citizens and residents of France for acts committed within France and abroad (http://www.loc.gov/law/help/foreign-fighters/countrysurveys.php). This 2012 legislation also allows for the prosecution of French citizens who return to France after committing an act of terrorism abroad, or after training in terrorist camp with the intention to return to France and commit terrorist acts. A November 13, 2014 law also prevents people from leaving the country when there are reasons to believe that they intend to engage in illicit terrorist activities abroad (http://www.state.gov/j/ct/rls/crt/2014/239406.htm). In January 2014, French officials arrested three individuals at the Saint-Etienne Airport. The individuals were planning to travel to Syria and were charged with preparing to commit terrorist acts, and the prosecutor asked for a sentence ranging from two to six years' imprisonment. (http://www.css.ethz.ch/publications/pdfs/Foreign Fighters_2014.pdf). Following the attacks on Charlie Hebdo, Prime Minister Manuel Valls stated that he would create a database listing the names of those who, among other things, were members of a terrorist fighting group, which would force those listed to notify the government of any trip abroad. The November 13, 2014 law also authorized the Interior Ministry to void or confiscate the passports of people considered to be potential terrorist threats (http://www.nytimes.com/2015/01/22/world/ europe/amedy-coulibaly-paris-gunman-france.html).

Penalizing foreign terrorist fighter conduct: 10 out of 10 (see methodology section).

The 2012 legislation also allows for the prosecution of French citizens who return to France after 
committing an act of terrorism abroad, or after training in terrorist camp with the intention to return to France and commit terrorist acts. A November 13, 2014 law also prevents people from leaving the country when there are reasons to believe that they intend to engage in illicit terrorist activities abroad (http://www.state.gov/j/ct/rls/crt/2014/239406.htm).

Penalize funding to foreign terrorist fighters: 10 out of 10 (see methodology section).

France belongs to the FATF and regional FATF-related bodies. "In January 2014, the French Treasury froze the assets of a nonprofit association called 'Perle d'Espoir' (Pearl of Hope), and later arrested two employees of that organization for terrorist financing and conspiracy" (http://www.state.gov/j/ $\mathrm{ct} / \mathrm{rls} / \mathrm{crt} / 2014 / 239406 . \mathrm{htm})$. France has worked closely with the United States "for the exchange and evaluation of terrorist-relating information and partnered in fostering closer regional and international cooperation" (http://www.state.gov/j/ct/rls/crt/2014/239406.htm). France is also a member of the Global Coalition to Counter the Islamist State of Iraq and the Levant (ISIL). Additionally, France undertook joint counterterrorism operations with the UK, Belgium, Germany, Italy, and Spain, and has taken steps to assist other countries with building their counterterrorism capacity (http://www.state. gov/j/ct/rls/crt/2014/239406.htm).

Penalize the facilitation of (including organization and recruitment of) foreign terrorist fighters: 10 out of 10 (see methodology section).

Article 421 of the French Penal Code criminalizes "conspiracy with a terrorist enterprise," defined as "participating in a group formed, or agreement made, for the purpose of preparing" a terrorist act. This crime is punishable by up to ten years' imprisonment and a fine of 225,000 euros. If the individual has assumed a leadership role in the organization, the penalty increases to up to 20 years' imprisonment and a fine of 500,000 euros (http://www.loc.gov/law/help/foreign-fighters/country-surveys.php).

\section{Bring foreign terrorist fighters to "justice": 10 out of 10 (see methodology section).}

Foreign fighters that return to France are "systematically questioned" by French intelligence and law enforcement authorities, following which they are "almost always detained and charged with conspiracy with a terrorist enterprise" (http://www.loc.gov/law/help/foreign-fighters/country-surveys. php). As of October 7, 2014, approximately 50 returned foreign fighters were detained, although they had not yet been tried for "conspiracy with a terrorist enterprise" (http://www.loc.gov/law/help/foreignfighters/country-surveys.php).

\section{Support of five key aspects of principled humanitarian action in counterterrorism contexts}

\section{Points allocated: $\mathbf{3 4}$ out of $\mathbf{5 0}$ (see methodology section).}

Knowability of anti-terrorism lists: 10 out of 10 (see methodology section).

While France does not appear to maintain a domestic terrorist list, the country belongs to the European Union, which does maintain publicly available terrorist lists that encompass the provisions of the al-Qaeda sanctions and other relevant Security Council measures (http://www.consilium.europa. eu/en/policies/fight-against-terrorism/terrorist-list/). France does provide procedures for freezing 
assets pursuant to UNSCR 1373, and recognizes Daesh (ISIS) as a terrorist organization (http://www. diplomatie.gouv.fr/en/french-foreign-policy/defence-security/terrorism).

Ease of navigability and efficiency of the regulatory system: 10 out of 10 (see methodology section). Initial research suggests that the relevant portions of the regulatory system are relatively easy to navigate and efficient (http://www.cof.org/content/france).

Explicit exemptions from counterterrorism measures of principled humanitarian action: 0 out of 10 (see methodology section).

Initial research suggests that the domestic legislation, if any, limiting travel to conflict zones involving terrorists does not exempt staff of principled humanitarian organizations (expressly or as a subset of non-profit organizations, automatically or potentially through a petition/license); that domestic legislation, if any, applicable within the territory of the state and/or extraterritorially restricting engagement with terrorists does not exempt impartial wartime medical care for terrorists; and that relevant domestic legislation, if any, does not exempt other forms of principled humanitarian action in conflict zones involving terrorists.

No reported legal proceedings on the basis of principled humanitarian action in conflict zones involving terrorists nor reported "chilling effect" (self-imposed curtailment) of principled humanitarian action due to state counterterrorism measures: 10 out of 10 (see methodology section).

Initial research did not uncover evidence that the state has instituted criminal or civil counterterrorism proceedings on the basis of engaging in principled humanitarian action in conflict zones involving terrorists. Nor did initial research uncover evidence that the state's domestic counterterrorism legislation had or has a reported "chilling effect" on principled humanitarian organizations.

Financial support via designated channel to Iraq and Syria in 2015 (to date) as a percentage of GDP: 4 out of 10 (see methodology section).

0.0001\% (http://data.worldbank.org/indicator/NY.GDP.MKTP.CD and https://fts.unocha.org/pageloader. aspx?page=search-customsearch).

\section{GERMANY}

\section{Compliance with five key foreign terrorist fighter elements of Resolution 2178 (2014)}

\section{Points allocated: 47 out of $\mathbf{5 0}$ (see methodology section).}

Preventing and suppressing foreign terrorist fighter travel: 7 out of 10 (see methodology section).

Assessment criterion i: 6 out of 8. Assessment criteria ii and iii: 1 out of 2: German counterterrorism law criminalizes the membership in or support for domestic and foreign terrorist organizations, and the provision of financial or material support for terrorist groups or acts, as well as attendance at terrorist 
training camps. In September 2014, the Ministry of Interior made it explicitly illegal to join, recruit, provide material support for, propagandize for, or display the symbols of ISIS. (http://www.state.gov/j/ $\mathrm{ct} / \mathrm{rls} / \mathrm{crt} / 2014 / 239406 . \mathrm{htm})$. German officials have made use of existing counterterrorism provisions to seize passports of those individuals deemed to pose a security risk and began preparatory work on other measures to block travel, such as limitations on national identification cards. German passports and other identity documents have "strong security features." Germany, however, does not collect entry or exit data. (http://www.state.gov/j/ct/rls/crt/2014/239406.htm). Government officials work closely with border officials in Turkey to exchange information on travelers who may be foreign fighters (http://www.loc.gov/law/help/foreign-fighters/country-surveys.php).

\section{Penalizing foreign terrorist fighter conduct: 10 out of 10 (see methodology section).}

German counterterrorism law criminalizes the membership in or support for domestic and foreign terrorist organizations, and the provision of financial or material support for terrorist groups or acts, as well as attendance at terrorist training camps. In September 2014, the Ministry of Interior made it explicitly illegal to join, recruit, provide material support for, propagandize for, or display the symbols of ISIS (http://www.state.gov/j/ct/rls/crt/2014/239406.htm).

Penalize funding to foreign terrorist fighters: 10 out of 10 (see methodology section).

Germany is a member of the FATF and an observer of several FATF-style regional bodies. In April, the Ministry of the Interior banned a Hezbollah-affiliated charity, the Lebanese Orphan Children Project, and seized nearly $\$ 80,000$ (U.S.) in assets (http://www.state.gov/j/ct/rls/crt/2014/239406.htm). See also above concerning German counterterrorism legal provisions.

Penalize the facilitation of (including organization and recruitment of) foreign terrorist fighters: 10 out of 10 (see methodology section).

The German Criminal Code criminalizes participation in terrorist training. Section 129 criminalizes the formation of criminal organizations, or those who participate in organizations as a member, recruit members or supporters, or support it themselves. These crimes are punishable by five years' imprisonment or a fine. Individuals who form terrorist organizations or who participate in those groups as a member may receive one to ten years' imprisonment. Recruitment for terrorist organizations is punishable by six months to five years' imprisonment. These provisions, under Section 129b, also apply to organizations abroad (http://www.gesetze-im-internet.de/englisch_stgb/englisch_stgb.html).

Bring foreign terrorist fighters to "justice": 10 out of 10 (see methodology section).

"German officials actively investigated [German foreign fighter] returnees for any terrorist threat resulting from their experience abroad....At the end of 2014, the Federal Minister of Justice said authorities were carrying out approximately 300 investigations or prosecutions nationwide related to ISIL membership or support" (http://www.state.gov/j/ct/rls/crt/2014/239406.htm).

\section{Support of five key aspects of principled humanitarian action in counterterrorism contexts}

\section{Points allocated: $\mathbf{3 8}$ out of $\mathbf{5 0}$ (see methodology section).}


Knowability of anti-terrorism lists: 10 out of 10 (see methodology section).

While German law allows for the proscription of terrorists, initial research was inconclusive as to whether Germany maintains a domestic terrorist list (Martha Crenshaw (ed.), The Consequences of Terrorism (2010), at 50). Germany belongs to the European Union, however, which does maintain publicly available terrorist lists that encompass the provisions of the al-Qaeda sanctions and other relevant Security Council measures (http://www.consilium.europa.eu/en/policies/fight-againstterrorism/terrorist-list/).

Ease of navigability and efficiency of the regulatory system: 10 out of 10 (see methodology section).

Initial research suggests that the relevant portions of the regulatory system are relatively easy to navigate and efficient (http://www.cof.org/content/germany\#Activities).

Explicit exemptions from counterterrorism measures of principled humanitarian action: 0 out of 10 (see methodology section).

Initial research suggests that the domestic legislation, if any, limiting travel to conflict zones involving terrorists does not exempt staff of principled humanitarian organizations (expressly or as a subset of non-profit organizations, automatically or potentially through a petition/license); that domestic legislation, if any, applicable within the territory of the state and/or extraterritorially restricting engagement with terrorists does not exempt impartial wartime medical care for terrorists; and that relevant domestic legislation, if any, does not exempt other forms of principled humanitarian action in conflict zones involving terrorists.

No reported legal proceedings on the basis of principled humanitarian action in conflict zones involving terrorists nor reported "chilling effect" (self-imposed curtailment) of principled humanitarian action due to state counterterrorism measures: 10 out of 10 (see methodology section).

Initial research did not uncover evidence that the state has instituted criminal or civil counterterrorism proceedings on the basis of engaging in principled humanitarian action in conflict zones involving terrorists. Nor did initial research uncover evidence that the state's domestic counterterrorism legislation had or has a reported "chilling effect" on principled humanitarian organizations.

Financial support via designated channel to Iraq and Syria in 2015 (to date) as a percentage of GDP: 8 out of 10 (see methodology section).

0.00531\% (http://data.worldbank.org/indicator/NY.GDP.MKTP.CD and https://fts.unocha.org/ pageloader.aspx?page=search-customsearch).

\section{JORDAN}

\section{Compliance with five key foreign terrorist fighter elements of Resolution 2178 (2014)}

\section{Points allocated: $\mathbf{3 4}$ out of $\mathbf{5 0}$ (see methodology section).}


Preventing and suppressing foreign terrorist fighter travel: 2 out of 10 (see methodology section) (assessment criteria i: 0 [out of 8]).

Assessment criterion i: 0 out of 8. Assessment criteria ii and iii: 2 out of 2. Article 3c of Law 55 of 2006, amended by Law 18 of 2014, prohibits Jordanian citizens from joining military groups and terrorist organizations inside the country and abroad (http://www.loc.gov/law/help/foreign-fighters/countrysurveys.php). "Jordan continued to develop its border security infrastructure, largely through the Jordan Border Security Program, which began in 2009 and consists of a sophisticated package of sensors to help improve situational awareness along the border. Jordan also uses biographic and biometric screening and engages in passenger information sharing. The Jordan Border Security Program aims to prevent infiltrations into Jordan or unauthorized departures. Jordan actively monitors airports and border crossings for potential foreign fighters" (http://www.state.gov/j/ct/rls/ crt/2014/239407.htm).

Penalizing foreign terrorist fighter conduct: 6 out of 10 (see methodology section).

Article 3c of Law 55 of 2006, amended by Law 18 of 2014, prohibits Jordanian citizens from receiving any military training from terrorist organizations within the country or abroad. Individuals committing these offenses may be imprisoned (http://www.loc.gov/law/help/foreign-fighters/country-surveys. php). The Jordanian Parliament amended its 2006 Anti-Terrorism Law in April 2014, broadening the definition of terrorism to include forming a group with the intention to commit terrorist acts; harming relations with a foreign state; using the internet to facilitate terrorist acts or promote terrorist ideas; and attacks on the life or liberty of the royal family. The Jordanian Penal Code defines terrorism broadly, to include acts that "contravene the public order." (http://www.state.gov/j/ct/rls/crt/2014/239407.htm).

\section{Penalize funding to foreign terrorist fighters: 6 out of 10 (see methodology section).}

"Jordan is a member of the Middle East and North Africa FATF, a FATF-style regional body. Although the Parliament introduced amendments to its counterterrorist financing law, which would bring Jordan more in line with international standards, the amendments had not been adopted by December 2014 . No known prosecution of terrorist financing occurred in 2014. The Associations Law requires nonprofit organizations to apply for Cabinet approval before receiving foreign funds. Jordan's Anti-Money Laundering Law does not require nonprofit organizations to file suspicious transaction reports. Jordan participated actively in the Global Coalition to Counter ISIL. It also actively engages in passenger information sharing" (http://www.state.gov/j/ct/rls/crt/2014/239407.htm).

Penalize the facilitation of (including organization and recruitment of) foreign terrorist fighters: 10 out of 10 (see methodology section).

Jordan has arrested and charged individuals for recruiting or otherwise supporting ISIS (http:// www.state.gov/j/ct/rls/crt/2014/239407.htm). See also above regarding the scope of Jordanian counterterrorism law.

Bring foreign terrorist fighters to "justice": 10 out of 10 (see methodology section).

“During 2014, Jordanian authorities took legal action against individuals accused of seeking to join ISIS; recruiting for or otherwise supporting ISIS, especially on the internet; and attempting to travel to or return from Syria to fight with extremist groups. Beginning in August 2014, security officials arrested over 100 ISIS supporters, many for posting pro-ISIS videos or statements on social medial sites, 
charging them with using the internet to propagate terrorist ideology. Officials also regularly arrested departing or returning Jordanian foreign fighters, charging them with joining armed groups" (http:// www.state.gov/j/ct/rls/crt/2014/239407.htm).

\section{Support of five key aspects of principled humanitarian action in counterterrorism contexts}

\section{Points allocated: 17 out of $\mathbf{5 0}$ (see methodology section).}

Knowability of anti-terrorism lists: 0 out of 10 (see methodology section).

Initial research did not uncover evidence that the state has established a domestic anti-terrorism list (at a minimum, a list implementing binding Security Council-imposed al-Qaeda-related sanctions) and/or made the requisite measures relating to that list publicly available.

Ease of navigability and efficiency of the regulatory system: 5 out of 10 (see methodology section).

Initial research suggests that the relevant portions of the regulatory system are relatively challenging to navigate and/or relatively inefficient. For example, associations, foundations, and not-for-profit companies may not have any "political goals," and cannot participate in "activities of political parties." Prior approval is required before the receipt of foreign donations, and government officials must be notified 48 hours in advance of any assembly (http://www.icnl.org/research/monitor/jordan.html).

Explicit exemptions from counterterrorism measures of principled humanitarian action: 0 out of 10 (see methodology section).

Initial research suggests that the domestic legislation, if any, limiting travel to conflict zones involving terrorists does not exempt staff of principled humanitarian organizations (expressly or as a subset of non-profit organizations, automatically or potentially through a petition/license); that domestic legislation, if any, applicable within the territory of the state and/or extraterritorially restricting engagement with terrorists does not exempt impartial wartime medical care for terrorists; and that relevant domestic legislation, if any, does not exempt other forms of principled humanitarian action in conflict zones involving terrorists.

No reported legal proceedings on the basis of principled humanitarian action in conflict zones involving terrorists nor reported "chilling effect" (self-imposed curtailment) of principled humanitarian action due to state counterterrorism measures: 10 out of 10 (see methodology section).

Initial research did not uncover evidence that the state has instituted criminal or civil counterterrorism proceedings on the basis of engaging in principled humanitarian action in conflict zones involving terrorists. Nor did initial research uncover evidence that the state's domestic counterterrorism legislation had or has a reported "chilling effect" on principled humanitarian organizations.

Financial support via designated channel to Iraq and Syria in 2015 (to date) as a percentage of GDP: 2 out of 10 (see methodology section).

$0 \%$ (no financial assistance reportedly provided via the designated funding channel) (http://data. worldbank.org/indicator/NY.GDP.MKTP.CD and https://fts.unocha.org/pageloader.aspx?page=searchcustomsearch). 


\section{LEBANON}

\section{Compliance with five key foreign terrorist fighter elements of Resolution 2178 (2014)}

\section{Points allocated: 16 out of 50 (see methodology section).}

Preventing and suppressing foreign terrorist fighter travel: 0 out of 10 (see methodology section).

Assessment criterion i: 0 out of 8 . Assessment criteria ii and iii: 0 out of 2 . The Lebanese security forces seek to limit ISIS's threat, including the flow of foreign fighters to and from Syria, by working to secure the porous, ungoverned border with Syria and conducting counterterrorism operations within Lebanon. The government has increased security measures at airports and border crossings to prevent the flow of foreign fighters to Syria and Iraq. Lebanon does not have biometric systems, however, in place at official ports of entry. Lebanese officials were considering the adoption of biometric passports. Lebanon uses an electronic database to collect biographic data for travelers at all ports of entry. "The government was not in full compliance with UNSCR 2178 at year's end, however, since it has not taken significant action to prevent Hizballah from sending its fighters to Syria and Iraq." (http://www.state. gov/j/ct/rls/crt/2014/239407.htm).

Penalizing foreign terrorist fighter conduct: 2 out of 10 (see methodology section).

"Lebanon does not have a comprehensive counterterrorism law, but several provisions of its criminal code are used to prosecute terrorist acts; however, implementation of these provisions has been complicated by Lebanon's complex political and confessional system, and by Hizballah restricting access to attack sites within areas under its control" (http://www.state.gov/j/ct/rls/crt/2014/239407. htm).

Penalize funding to foreign terrorist fighters: 6 out of 10 (see methodology section).

Lebanon is a member of the Middle East and North Africa FATF, a FATF-style regional body. Lebanon is a member of the Global Coalition to Counter ISIL. Lebanon's financial intelligence unit (SIC) can investigate suspicious financial transactions and freeze assets. Neither the SIC or the ISF received any allegations of terrorist financing that led to terrorist financing cases in 2014. NGOs must submit a yearly financial statement to the government, but are not required to file suspicious transaction reports to prevent terrorist financing; however, the banking sector subjects NGOs to enhanced due diligence and reports suspicious transactions to the SIC (http://www.state.gov/j/ct/rls/crt/2014/239407.htm).

Penalize the facilitation of (including organization and recruitment of) foreign terrorist fighters: 6 out of 10 (see methodology section).

The Internal Security Forces (ISF) have worked to prevent terrorist recruitment and the direction of terrorist activities by prison inmates, who, in many cases, have complete control of certain cell blocks, and access to cell phones and the Internet (http://www.state.gov/j/ct/rls/crt/2014/239407.htm).

Bring foreign terrorist fighters to "justice": 2 out of 10 (see methodology section).

Initial research did not uncover evidence that the state has ensured that any person who participates 
in the financing, planning, preparation, or perpetration of terrorist acts or in supporting terrorist acts is brought to justice.

\section{Support of five key aspects of principled humanitarian action in counterterrorism contexts}

\section{Points allocated: 17 out of $\mathbf{5 0}$ (see methodology section).}

Knowability of anti-terrorism lists: 0 out of 10 (see methodology section).

Initial research did not uncover evidence that the state has established a domestic anti-terrorism list (at a minimum, a list implementing binding Security Council-imposed al-Qaeda-related sanctions) and/or made the requisite measures relating to that list publicly available.

Ease of navigability and efficiency of the regulatory system: 5 out of 10 (see methodology section).

Lebanese associations must notify the government immediately after they are created, and the government will issue a receipt of notification, after which an association can take advantages of all the legal rights and privileges of legal associations. Associations have faced restrictions, however, following the crisis in Syria, as government officials have moved to restrict NGO activities, including economic support programs (http://www.icnl.org/research/monitor/lebanon.html).

Explicit exemptions from counterterrorism measures of principled humanitarian action: 0 out of 10 (see methodology section).

Initial research suggests that the domestic legislation, if any, limiting travel to conflict zones involving terrorists does not exempt staff of principled humanitarian organizations (expressly or as a subset of non-profit organizations, automatically or potentially through a petition/license); that domestic legislation, if any, applicable within the territory of the state and/or extraterritorially restricting engagement with terrorists does not exempt impartial wartime medical care for terrorists; and that relevant domestic legislation, if any, does not exempt other forms of principled humanitarian action in conflict zones involving terrorists.

No reported legal proceedings on the basis of principled humanitarian action in conflict zones involving terrorists nor reported "chilling effect" (self-imposed curtailment) of principled humanitarian action due to state counterterrorism measures: 10 out of 10 (see methodology section).

Initial research did not uncover evidence that the state has instituted criminal or civil counterterrorism proceedings on the basis of engaging in principled humanitarian action in conflict zones involving terrorists. Nor did initial research uncover evidence that the state's domestic counterterrorism legislation had or has a reported "chilling effect" on principled humanitarian organizations.

Financial support via designated channel to Iraq and Syria in 2015 (to date) as a percentage of GDP: 2 out of 10 (see methodology section).

0\% (no financial assistance reportedly provided via the designated funding channel) (http://data. worldbank.org/indicator/NY.GDP.MKTP.CD and https://fts.unocha.org/pageloader.aspx?page=searchcustomsearch). 


\section{LIBYA}

\section{Compliance with five key foreign terrorist fighter elements of Resolution 2178 (2014)}

\section{Points allocated: 8 out of $\mathbf{5 0}$ (see methodology section).}

Preventing and suppressing foreign terrorist fighter travel: 0 out of 10 (see methodology section).

Assessment criterion i: 0 out of 8. Assessment criteria ii and iii: 0 out of 2: Libya has a draft counterterrorism law, prepared by the interim government, that would define a terrorist organization as a group of three or more persons established to commit terrorist crimes within or outside Libya. If enacted, Article 9 would criminalize the act of joining such an organization, either within or outside Libya (http://www.loc.gov/law/help/foreign-fighters/country-surveys.php). Libya's porous borders and "critically weak" law enforcement continued to make it a permissive environment for terrorist groups. (http://www.loc.gov/law/help/foreign-fighters/country-surveys.php). The Libyan government lacks a comprehensive border management strategy and has struggled to secure the country's land and sea borders, enabling the flow of foreign fighters, among other illicit items, that pose serious security challenges to the region. Border security forces are ineffective and often participate in illicit crossborder trade. Security at airports is minimal, with limited document screening and no use of passenger name record systems or biometric technology (http://www.state.gov/j/ct/rls/crt/2014/239407.htm).

Penalizing foreign terrorist fighter conduct: 2 out of 10 (see methodology section).

Libya lacks a comprehensive counterterrorism law, although the Libyan Penal Code criminalizes offenses prejudicial to state security, including terrorism and the promotion of terrorist acts. Libyan law enforcement lacks the capacity to detect, deter, respond to, or investigate terrorist incidents (http:// www.loc.gov/law/help/foreign-fighters/country-surveys.php).

Penalize funding to foreign terrorist fighters: 2 out of 10 (see methodology section).

Libya lacks a comprehensive counterterrorism law, although the Libyan Penal Code criminalizes offenses prejudicial to state security, including the handling of money in support of such acts (http:// www.loc.gov/law/help/foreign-fighters/country-surveys.php). Libya is a member of the Middle East and North Africa FATF, a FATF-style regional body. "Libyan government and financial institutions lack the ability to identify and interdict illicit financial transactions" (http://www.state.gov/j/ct/rls/ crt/2014/239407.htm).

Penalize the facilitation of (including organization and recruitment of) foreign terrorist fighters: 2 out of 10 (see methodology section).

Initial research did not uncover evidence that the state has ensured that domestic laws and regulations establish serious criminal offenses sufficient to provide the ability to prosecute and penalize the willful organization, or other facilitation, including acts of recruitment, by their nationals or in their territories, of the travel of individuals who travel to a state other than their states of residence or nationality for the purpose of the perpetration, planning, preparation of, or participation in, terrorist acts or the provide or receiving of terrorist training. 
Bring foreign terrorist fighters to "justice": 2 out of 10 (see methodology section).

Initial research did not uncover evidence that the state has ensured that any person who participates in the financing, planning, preparation, or perpetration of terrorist acts or in supporting terrorist acts is brought to justice.

\section{Support of five key aspects of principled humanitarian action in counterterrorism contexts}

\section{Points allocated: 22 out of $\mathbf{5 0}$ (see methodology section).}

Knowability of anti-terrorism lists: 0 out of 10 (see methodology section).

Initial research did not uncover evidence that the state has established a domestic anti-terrorism list (at a minimum, a list implementing binding Security Council-imposed al-Qaeda-related sanctions) and/or made the requisite measures relating to that list publicly available.

Ease of navigability and efficiency of the regulatory system: 10 out of 10 (see methodology section).

Initial research suggests that the relevant portions of the regulatory system are relatively easy to navigate and efficient (http://www.icnl.org/research/monitor/jordan.html).

Explicit exemptions from counterterrorism measures of principled humanitarian action: 0 out of 10 (see methodology section).

Initial research suggests that the domestic legislation, if any, limiting travel to conflict zones involving terrorists does not exempt staff of principled humanitarian organizations (expressly or as a subset of non-profit organizations, automatically or potentially through a petition/license); that domestic legislation, if any, applicable within the territory of the state and/or extraterritorially restricting engagement with terrorists does not exempt impartial wartime medical care for terrorists; and that relevant domestic legislation, if any, does not exempt other forms of principled humanitarian action in conflict zones involving terrorists.

No reported legal proceedings on the basis of principled humanitarian action in conflict zones involving terrorists nor reported "chilling effect" (self-imposed curtailment) of principled humanitarian action due to state counterterrorism measures: 10 out of 10 (see methodology section).

Initial research did not uncover evidence that the state has instituted criminal or civil counterterrorism proceedings on the basis of engaging in principled humanitarian action in conflict zones involving terrorists. Nor did initial research uncover evidence that the state's domestic counterterrorism legislation had or has a reported "chilling effect" on principled humanitarian organizations.

Financial support via designated channel to Iraq and Syria in 2015 (to date) as a percentage of GDP: 2 out of 10 (see methodology section).

0\% (no financial assistance reportedly provided via the designated funding channel) (http://data. worldbank.org/indicator/NY.GDP.MKTP.CD and https://fts.unocha.org/pageloader.aspx?page=searchcustomsearch). 


\section{MOROCCO}

\section{Compliance with five key foreign terrorist fighter elements of Resolution 2178 (2014)}

\section{Points allocated: $\mathbf{3 5}$ out of $\mathbf{5 0}$ (see methodology section).}

Preventing and suppressing foreign terrorist fighter travel: 3 out of 10 (see methodology section).

Assessment criterion i: 2 out of 8. Assessment criteria ii and iii: 1 out of 2: Government airport authorities can detect fraudulent documents but currently lack biometric screening capabilities (http:// www.state.gov/j/ct/rls/crt/2014/239407.htm).

Penalizing foreign terrorist fighter conduct: 10 out of 10 (see methodology section).

As of December 2014, the Moroccan government was reviewing draft amendments to its criminal codes to comply with UNSCR 2178 by criminalizing support to terrorist groups, travel to fight or train in conflict areas, and recruitment of others for such acts (http://www.state.gov/j/ct/rls/crt/2014/239407. $\mathrm{htm}$ ). These amendments later passed and were published in the official gazette (http://81.192.52.100/ BO/AR/2015/BO_6365_Ar.pdf).

Penalize funding to foreign terrorist fighters: 6 out of 10 (see methodology section).

Morocco is a member of the Middle East and North Africa FATF, a FATF-style regional body. In March 2014, officials arrested four individuals for terrorist financing and the recruitment of youth to travel to Syria to fight. Law enforcement officials in Morocco, along with private carriers, have worked regularly with the United States to detect and deter individuals attempt to transit illegally through Morocco (http://www.state.gov/j/ct/rls/crt/2014/239407.htm).

Penalize the facilitation of (including organization and recruitment of) foreign terrorist fighters: 6 out of 10 (see methodology section).

As of December 2014, the Moroccan government was reviewing draft amendments to its criminal codes to comply with UNSCR 2178 by criminalizing support to terrorist groups, travel to fight or train in conflict areas, and recruitment of others for such acts (http://www.state.gov/j/ct/rls/crt/2014/239407. $\mathrm{htm})$.

\section{Bring foreign terrorist fighters to "justice": 10 out of 10 (see methodology section).}

In July 2014, the Ministry of Interior claimed to have arrested over 120 foreign terrorist fighters who had returned from Syria since the start of the Syrian conflict. The government tried and convicted individuals for recruiting volunteers for ISIS; raising funds and exporting people to conflict zones; preparing to join ISIS in Syria; and sentenced seven people to three years in prison for traveling to Syria and receiving military training (http://www.state.gov/j/ct/rls/crt/2014/239407.htm). 


\section{Support of five key aspects of principled humanitarian action in counterterrorism contexts}

\section{Points allocated: 17 out of 50 (see methodology section).}

Knowability of anti-terrorism lists: 0 out of 10 (see methodology section).

Initial research did not uncover evidence that the state has established a domestic anti-terrorism list (at a minimum, a list implementing binding Security Council-imposed al-Qaeda-related sanctions) and/or made the requisite measures relating to that list publicly available.

Ease of navigability and efficiency of the regulatory system: 5 out of 10 (see methodology).

Initial research suggests that the relevant portions of the regulatory system are relatively challenging to navigate and/or relatively inefficient (http://www.icnl.org/research/monitor/morocco.html).

Explicit exemptions from counterterrorism measures of principled humanitarian action: 0 out of 10 (see methodology section).

Initial research suggests that the domestic legislation, if any, limiting travel to conflict zones involving terrorists does not exempt staff of principled humanitarian organizations (expressly or as a subset of non-profit organizations, automatically or potentially through a petition/license); that domestic legislation, if any, applicable within the territory of the state and/or extraterritorially restricting engagement with terrorists does not exempt impartial wartime medical care for terrorists; and that relevant domestic legislation, if any, does not exempt other forms of principled humanitarian action in conflict zones involving terrorists.

No reported legal proceedings on the basis of principled humanitarian action in conflict zones involving terrorists nor reported "chilling effect" (self-imposed curtailment) of principled humanitarian action due to state counterterrorism measures: 10 out of 10 (see methodology section).

Initial research did not uncover evidence that the state has instituted criminal or civil counterterrorism proceedings on the basis of engaging in principled humanitarian action in conflict zones involving terrorists. Nor did initial research uncover evidence that the state's domestic counterterrorism legislation had or has a reported "chilling effect" on principled humanitarian organizations.

Financial support via designated channel to Iraq and Syria in 2015 (to date) as a percentage of GDP: 2 out of 10 (see methodology section).

0\% (no financial assistance reportedly provided via the designated funding channel) (http://data. worldbank.org/indicator/NY.GDP.MKTP.CD and https://fts.unocha.org/pageloader.aspx?page=searchcustomsearch). 


\section{The NetherLands}

\section{Compliance with five key foreign terrorist fighter elements of Resolution 2178 (2014)}

\section{Points allocated: $\mathbf{4 6}$ out of $\mathbf{5 0}$ (see methodology section).}

Preventing and suppressing foreign terrorist fighter travel: 6 out of 10 (see methodology section).

Assessment criterion i: 4 out of 8. Assessment criteria ii and iii: 2 out of 2: The Dutch Ministers of Social

Affairs and Employment and of Security and Justice have formulated an "Action Plan: Integrated Approach to Jihadism," in order to "protect democracy and the rule of law, counter and weaken the jihadist movement in the Netherlands, and eliminate the causes of radicalization."The action plan's 38 measures would allow for the revocation of the nationality of jihadists who joined a terrorist group (unless doing so would render them stateless); requiring periodic reporting of returned foreign fighters; and preparing legislation to permit "the systematic collection and processing of travel data for the purpose of counterterrorism" (http://www.loc.gov/law/help/foreign-fighters/country-surveys. php). The Dutch government prevents outbound terrorist foreign fighters from leaving the country, when possible, through punitive and administrative measures (e.g., revoking passports or halting social welfare benefits) (http://www.state.gov/j/ct/rls/crt/2014/239406.htm). As of December 2014, it had revoked 53 passports of potential foreign terrorist fighters. In December 2014, the government began the consultation process on draft legislation to revoke citizenship, without a court ruling, of dual national foreign terrorist fighters who have joined a designated terrorist organization. Dutch ports of entry have biographic and biometric screening capabilities (http://www.state.gov/j/ct/rls/ crt/2014/239406.htm).

\section{Penalizing foreign terrorist fighter conduct: 10 out of 10 (see methodology section).}

Under Article 134a of the Dutch Penal Code, "Participating in armed jihad or jihadist training abroad is a criminal offense," and it also makes it illegal "to furnish oneself or another intentionally the opportunity, resources, or intelligence, or to try to do so, in order to commit a terrorist crime or a crime in preparation or facilitation of a terrorist crime, or to acquire knowledge or skills to this end or impart these to another" (http://www.css.ethz.ch/publications/pdfs/Foreign_Fighters_2014.pdf)

Penalize funding to foreign terrorist fighters: 10 out of 10 (see methodology section).

The Netherlands is a member of the FATF and a cooperating and supporting nation of a FATF-style regional body. The Netherlands immediately freezes assets of individuals on terrorist watch lists (including UN, EU, and its own national designations), and Dutch authorities monitor financial transactions (http://www.state.gov/j/ct/rls/crt/2014/239406.htm). The United States reports "cooperation with U.S. law enforcement [and the Netherlands] remained excellent." The government coordinates and shares information related to foreign terrorist fighters with Interpol and Europol. The Dutch have taken a lead role in the EU to establish protocols against terrorist financing and have provided funds to the IMF for assistance to countries that lack the resources to implement these measures expeditiously. The Dutch participate in a broad range of regional and international counterterrorism forums (http://www.state.gov/j/ct/rls/crt/2014/239406.htm). 
Penalize the facilitation of (including organization and recruitment of) foreign terrorist fighters: 10 out of 10 (see methodology section).

Article 205 of the Dutch Criminal Code punishes recruitment for terrorism purposes and can be applied to foreign terrorist fighters (http://www.css.ethz.ch/publications/pdfs/Foreign_Fighters_2014.pdf).

Article 132(3) states that persons who disseminate material inciting others to commit terrorist offenses or to facilitate or prepare terrorist offenses may be punished with up to four years' imprisonment (http://ec.europa.eu/dgs/home-affairs/e-library/documents/policies/crisis-and-terrorism/general/ docs/report_on_the_implementation_of_cfd_2008-919-jha_and_cfd_2002-475-jha_on_combating_ terrorism_swd_en.pdf).

Bring foreign terrorist fighters to "justice": 10 out of 10 (see methodology section).

The Dutch government has pursued criminal cases against prospective and returned foreign terrorist fighters and against foreign terrorist fighter recruiters. Multiple cases have been brought against suspected or known foreign terrorist fighters, as well as individuals committing other terrorist offenses, such as financing terrorism, planning terrorist attacks, and recruiting individuals to travel to Syria (http://www.state.gov/j/ct/rls/crt/2014/239406.htm).

\section{Support of five key aspects of principled humanitarian action in counterterrorism contexts}

\section{Points allocated: $\mathbf{3 8}$ out of $\mathbf{5 0}$ (see methodology section).}

Knowability of anti-terrorism lists: 10 out of 10 (see methodology section).

The Netherlands maintains a domestic terrorist list (see International Monetary Fund, Kingdom of The Netherlands: Detailed Assessment of Standards and Codes (2004), at 186); it also belongs to the European Union, which maintains publicly available terrorist lists that encompass the provisions of the al-Qaeda sanctions and other relevant Security Council measures (http://www.consilium.europa.eu/en/policies/ fight-against-terrorism/terrorist-list/).

Ease of navigability and efficiency of the regulatory system: 10 out of 10 (see methodology section).

Initial research suggests that the relevant portions of the regulatory system are relatively easy to navigate and efficient (see generally http://www.scp.nl/english/dsresource?objectid=22125).

Explicit exemptions from counterterrorism measures of principled humanitarian action: 0 out of 10 (see methodology section).

Initial research suggests that the domestic legislation, if any, limiting travel to conflict zones involving terrorists does not exempt staff of principled humanitarian organizations (expressly or as a subset of non-profit organizations, automatically or potentially through a petition/license); that domestic legislation, if any, applicable within the territory of the state and/or extraterritorially restricting engagement with terrorists does not exempt impartial wartime medical care for terrorists; and that relevant domestic legislation, if any, does not exempt other forms of principled humanitarian action in conflict zones involving terrorists. 
No reported legal proceedings on the basis of principled humanitarian action in conflict zones involving terrorists nor reported "chilling effect" (self-imposed curtailment) of principled humanitarian action due to state counterterrorism measures: 10 out of 10 (see methodology section).

Initial research did not uncover evidence that the state has instituted criminal or civil counterterrorism proceedings on the basis of engaging in principled humanitarian action in conflict zones involving terrorists. Nor did initial research uncover evidence that the state's domestic counterterrorism legislation had or has a reported "chilling effect" on principled humanitarian organizations.

Financial support via designated channel to Iraq and Syria in 2015 (to date) as a percentage of GDP: 8 out of 10 (see methodology section).

0.00636\% (http://data.worldbank.org/indicator/NY.GDP.MKTP.CD and https://fts.unocha.org/ pageloader.aspx?page=search-customsearch).

\section{New ZeALAND}

\section{Compliance with five key foreign terrorist fighter elements of Resolution 2178 (2014)}

\section{Points allocated: $\mathbf{2 5}$ out of $\mathbf{5 0}$ (see methodology section).}

Preventing and suppressing foreign terrorist fighter travel: 9 out of 10 (see methodology section).

Assessment criteria i: 8 out of 8 . Assessment criteria ii and iii: 1 out of 2: New anti-terrorism measures passed in late 2014 would allow the nation's domestic spy agency to surveil individuals for up to 24 hours without a warrant (http://www.theguardian.com/world/2014/dec/10/new-zealand-approvesanti-terrorism-laws-to-counter-foreign-fighters-risk). Changes to New Zealand law, made in late 2014, allow the Minister of Internal Affairs to cancel passports for up to three years and to temporarily suspend passports for up to 10 working days in urgent cases (http://www.loc.gov/law/help/foreignfighters/country-surveys.php).

Penalizing foreign terrorist fighter conduct: 2 out of 10 (see methodology section). Initial research did not uncover evidence that the state ensures that domestic laws and regulations establish serious criminal offenses sufficient to provide the ability to prosecute and penalize their nationals and other individuals who travel or attempt to travel to a state other than their states of residence or nationality, for the purpose of perpetration, planning, or preparation of, or participation in, terrorist acts, or providing or receiving terrorist training.

Penalize funding to foreign terrorist fighters: 10 out of 10 (see methodology section).

While it does not specifically mention foreign fighters, New Zealand law prohibits the provision of funding to terrorists in its Terrorism Suppression Act 2002. Providing funding to terrorists is punishable by 14 years' imprisonment (http://www.legislation.govt.nz/act/public/2002/0034/latest/ DLM152710.html). 
Penalize the facilitation of (including organization and recruitment of) foreign terrorist fighters: 2 out of 10 (see methodology section).

In October 2014, the New Zealand Prime Minister authorized a targeted review of security settings "to ensure that the capability, capacity, and legislation to counter the evolving domestic threat posted by foreign terrorist fighters and other violent extremists are adequate to meet that threat." (http://www. loc.gov/law/help/foreign-fighters/country-surveys.php).

Bring foreign terrorist fighters to "justice": 2 out of 10 (see methodology section).

Initial research did not uncover evidence that the state has ensured that any person who participates in the financing, planning, preparation, or perpetration of terrorist acts or in supporting terrorist acts is brought to justice.

\section{Support of five key aspects of principled humanitarian action in counterterrorism contexts}

\section{Points allocated: $\mathbf{3 9 . 5}$ out of $\mathbf{5 0}$ (see methodology section).}

Knowability of anti-terrorism lists: 10 out of 10 (see methodology section).

The New Zealand Police posts lists of designated terrorist entities pursuant to Resolutions 1267/1989 and 1988 (http://www.police.govt.nz/about-us/publication/designated-terrorist-entities), as well as of entities designated pursuant to authorities provided under Resolution 1373 (http://www.police. govt.nz/advice/personal-community/counterterrorism/designated-entities/lists-associated-withresolution-1373).

Ease of navigability and efficiency of the regulatory system: 10 out of 10 (see methodology section). Initial research suggests that the relevant portions of the regulatory system are relatively easy to navigate and efficient (http://www.icnl.org/research/journal/vol8iss3/art_3.htm). (New Zealand requires NGOs to be accredited to receive certain types of funding from the New Zealand Aid Programme (http://www.aid.govt.nz/funding-and-contracts/new-zealand-disaster-responsepartnership/accreditation).)

Explicit exemptions from counterterrorism measures of principled humanitarian action: 5.5 out of 10 (see methodology section).

Terrorism Suppression Act 2002 (NZ) s 10(3) provides, as an exception to the prohibition on making property, or financial or related services, available to designated terrorist entity, that "[a]n example of making property available with a reasonable excuse, for the purposes of subsection (1), is where the property (for example, items of food, clothing, or medicine) is made available in an act that does no more than satisfy essential human needs of (or of a dependent of) an individual designated under this Act."

No reported legal proceedings on the basis of principled humanitarian action in conflict zones involving terrorists nor reported "chilling effect" (self-imposed curtailment) of principled humanitarian action due to state counterterrorism measures: 10 out of 10 (see methodology section).

Initial research did not uncover evidence that the state has instituted criminal or civil counterterrorism 
proceedings on the basis of engaging in principled humanitarian action in conflict zones involving terrorists. Nor did initial research uncover evidence that the state's domestic counterterrorism legislation had or has a reported "chilling effect" on principled humanitarian organizations.

Financial support via designated channel to Iraq and Syria in 2015 (to date) as a percentage of GDP: 4 out of 10 (see methodology section).

0.00080\% (http://data.worldbank.org/indicator/NY.GDP.MKTP.CD and https://fts.unocha.org/ pageloader.aspx?page=search-customsearch).

\section{NoRWAY}

\section{Compliance with five key foreign terrorist fighter elements of Resolution 2178 (2014)}

\section{Points allocated: $\mathbf{4 5}$ out of $\mathbf{5 0}$ (see methodology section).}

Preventing and suppressing foreign terrorist fighter travel: 5 out of 10 (see methodology section).

Assessment criterion i: 4 out of 8. Assessment criteria ii and iii: 1 out of 2: Norway is currently reviewing new legislation that would criminalize Norwegian citizens from recruiting or participating as foreign terrorist fighters (http://www.loc.gov/law/help/foreign-fighters/country-surveys.php). (This law has been criticized as overbroad and for possibly affecting humanitarian assistance (http:// www.aftenposten.no/meninger/leder/Hastverksarbeid-Amot-IS-krigere-7739520.html).) Norwegian immigration officials use biometric equipment for fingerprinting arrivals from outside the Schengen area. Norway cannot revoke or permanently hold a citizen's passport for expressing support for a terrorist group, or expressing an interest to travel to Syria and Iraq (http://www.state.gov/j/ct/rls/ crt/2014/239406.htm).

Penalizing foreign terrorist fighter conduct: 10 out of 10 (see methodology section).

Current laws criminalize conducting or planning to conduct a terrorist act, receiving terrorist training, or providing material support to a terrorist organization with money, materials, recruitment, fighting, and related crimes. Serious terrorism offenses are punishable by a maximum sentence of 30 years' imprisonment (http://www.state.gov/j/ct/rls/crt/2014/239406.htm).

Penalize funding to foreign terrorist fighters: 10 out of 10 (see methodology section).

Current laws criminalize, among other things, providing material support to a terrorist organization with money. Norway is a member of the FATF and the Egmont Group, and in response to UNSCR 2178 the government established an interagency group to combat money laundering and terrorist finance. Nonprofit organizations are subject to strict accounting and regulatory requirements, and the Norwegian National Authority for Investigation and Prosecution of Economic and Environmental Crime is charged with monitoring and the periodic testing of these requirements. Norway participates in many international and regional counterterrorism forums, including work on countering violent extremism. (http://www.state.gov/j/ct/rls/crt/2014/239406.htm). 
Penalize the facilitation of (including organization and recruitment of) foreign terrorist fighters: 10 out of 10 (see methodology section).

The Norwegian Criminal Code criminalizes the planning of terrorism, as well as recruitment of terrorists. Three individuals have been recently tried under these laws for (allegedly) fighting in Syria (http://www.loc.gov/law/help/foreign-fighters/country-surveys.php).

Bring foreign terrorist fighters to "justice": 10 out of 10 (see methodology section).

The Norwegian Criminal Code criminalizes the planning of terrorism, as well as recruitment of terrorists. Three people have been recently tried under this legislation for fighting in Syria (http://www. loc.gov/law/help/foreign-fighters/country-surveys.php).

\section{Support of five key aspects of principled humanitarian action in counterterrorism contexts}

\section{Points allocated: $\mathbf{4 0}$ out of $\mathbf{5 0}$ (see methodology section).}

Knowability of anti-terrorism lists: 10 out of 10 (see methodology section).

In 2006, Norway announced that it would no longer adopt the EU terrorist list, and, instead, to maintain its neutrality, Norway would list groups independently (see, e.g., http://www.tnp.no/norway/ panorama/3734-norway-to-revise-terrorist-organizations-list-after-the-elections and Martha Crenshaw (ed.), The Consequences of Terrorism (2010), at 108).

Ease of navigability and efficiency of the regulatory system: 10 out of 10 (see methodology section).

Initial research suggests that the relevant portions of the regulatory system are relatively easy to navigate and efficient (http://www.brreg.no/english/registers/frivillighet/; Femida Handy \& Pamala Wiepking (eds.), The Palgrave Handbook of Global Philanthropy (2015), at 236-37).

Explicit exemptions from counterterrorism measures of principled humanitarian action: 0 out of 10 (see methodology section).

Initial research suggests that the domestic legislation, if any, limiting travel to conflict zones involving terrorists does not exempt staff of principled humanitarian organizations (expressly or as a subset of non-profit organizations, automatically or potentially through a petition/license); that domestic legislation, if any, applicable within the territory of the state and/or extraterritorially restricting engagement with terrorists does not exempt impartial wartime medical care for terrorists; and that relevant domestic legislation, if any, does not exempt other forms of principled humanitarian action in conflict zones involving terrorists.

No reported legal proceedings on the basis of principled humanitarian action in conflict zones involving terrorists nor reported "chilling effect" (self-imposed curtailment) of principled humanitarian action due to state counterterrorism measures: 10 out of 10 (see methodology section).

Initial research did not uncover evidence that the state has instituted criminal or civil counterterrorism proceedings on the basis of engaging in principled humanitarian action in conflict zones involving 
terrorists. Nor did initial research uncover evidence that the state's domestic counterterrorism legislation had or has a reported "chilling effect" on principled humanitarian organizations. (As noted above, Norway is currently reviewing new legislation that would criminalize Norwegian citizens from recruiting or participating as foreign terrorist fighters (http://www.loc.gov/law/help/foreign-fighters/ country-surveys.php). This draft law has been criticized as overbroad and for possibly affecting humanitarian assistance (http://www.aftenposten.no/meninger/leder/Hastverksarbeid-Amot-ISkrigere-7739520.html).)

Financial support via designated channel to Iraq and Syria in 2015 (to date) as a percentage of GDP: 10 out of 10 (see methodology section).

0.00825\% (http://data.worldbank.org/indicator/NY.GDP.MKTP.CD and https://fts.unocha.org/ pageloader.aspx?page=search-customsearch).

\section{PAKISTAN}

\section{Compliance with five key foreign terrorist fighter elements of Resolution 2178 (2014)}

\section{Points allocated: $\mathbf{3 3}$ out of $\mathbf{5 0}$ (see methodology section).}

Preventing and suppressing foreign terrorist fighter travel: 9 out of 10 (see methodology section).

Assessment criterion i: 8 out of 8. Assessment criteria ii and iii: 1 out of 2: The Pakistan Citizenship Act of 1951 provides the authority to revoke citizenship and cancel passports. The Passports Act of 1974 provides that Pakistan can cancel passports without notice to the individual if the person "has been engaged in subversive activities which are prejudicial to the interest of Pakistan or Pakistan's relations with any foreign power" (http://www.loc.gov/law/help/foreign-fighters/country-surveys.php). Pakistan is implementing biometric collection in national databases and screening at border land crossings with the International Border Management Security system. Pakistan collects advance passenger name records on commercial flights (http://www.state.gov/documents/organization/239631.pdf).

Penalizing foreign terrorist fighter conduct: 6 out of 10 (see methodology section).

In 2013, the Pakistani government passed the Anti-Terrorism Bill 2013, which amended the definition of terrorism to include threats and acts against a "foreign government or population or an international organization." The law also prohibits membership in proscribed organizations. Pakistan's Penal Code also prohibits certain "offenses against the state," including waging war against any power in alliance or at peace with Pakistan (http://www.loc.gov/law/help/foreign-fighters/country-surveys.php). In 2014, Pakistan promulgated new legislation that supported the investigation and prosecution of terrorist offenses (http://www.state.gov/documents/organization/239631.pdf).

\section{Penalize funding to foreign terrorist fighters: 6 out of 10 (see methodology section).}

In 2013, the Pakistani government passed the Anti-Terrorism Bill, which prohibits support and funding of proscribed terrorist organizations (http://www.loc.gov/law/help/foreign-fighters/country-surveys. 
php). Pakistan is a member of the Asia/Pacific Group on Money Laundering, a FATF-style regional body. The government adopted legislation that gave it the ability to freeze terrorist assets; however, as of the end of 2014, it had not yet been implemented. In 2014, Pakistan promulgated new legislation that supported the investigation and prosecution of terrorist offenses (http://www.state.gov/documents/ organization/239631.pdf). According to the U.S. State Department, cooperation with Pakistan during 2014 was "mixed," and the country continued to deny visas for trainers focused on law enforcement and civilian counterterrorism assistance (http://www.state.gov/documents/organization/239631.pdf).

Penalize the facilitation of (including organization and recruitment of) foreign terrorist fighters: 6 out of 10 (see methodology section).

In 2014, Pakistan promulgated new legislation that supported the investigation and prosecution of terrorist offenses (http://www.state.gov/documents/organization/239631.pdf).

Bring foreign terrorist fighters to "justice": 6 out of 10 (see methodology section).

In 2014, Pakistan promulgated new legislation that supported the investigation and prosecution of terrorist offenses (http://www.state.gov/documents/organization/239631.pdf). Pakistan continued to arrest terrorists and initiate prosecutions during 2014; however, problems persist throughout the criminal justice system, and intimidation by accused terrorists against witnesses, police, victims, prosecutors, defense lawyers, and judges contributed to both the slow progress of cases in anti-terrorism courts, and a high acquittal rate (http://www.state.gov/documents/organization/239631.pdf).

\section{Support of five key aspects of principled humanitarian action in counterterrorism contexts}

\section{Points allocated: 27 out of 50 (see methodology section).}

Knowability of anti-terrorism lists: 10 out of 10 (see methodology section).

Pakistan maintains a publicly available domestic list of designated terrorists (http://www.satp. org/satporgtp/countries/Pakistan/terroristoutfits/group_list.htm; see also http://pakarmedforces. com/2014/02/list-of-60-terrorist-organizations-declared-terrorists-by-government-of-pakistan.html).

Ease of navigability and efficiency of the regulatory system: 5 out of 10 (see methodology section).

Initial research suggests that the relevant portions of the regulatory system are relatively challenging to navigate and/or relatively inefficient. For instance, international NGOs may work only in specified areas, and NGOs may not work in specified "security zones." (http://www.icnl.org/research/monitor/ pakistan.html).

Explicit exemptions from counterterrorism measures of principled humanitarian action: 0 out of 10 (see methodology section).

Initial research suggests that the domestic legislation, if any, limiting travel to conflict zones involving terrorists does not exempt staff of principled humanitarian organizations (expressly or as a subset of non-profit organizations, automatically or potentially through a petition/license); that domestic legislation, if any, applicable within the territory of the state and/or extraterritorially restricting 
engagement with terrorists does not exempt impartial wartime medical care for terrorists; and that relevant domestic legislation, if any, does not exempt other forms of principled humanitarian action in conflict zones involving terrorists.

No reported legal proceedings on the basis of principled humanitarian action in conflict zones involving terrorists nor reported "chilling effect" (self-imposed curtailment) of principled humanitarian action due to state counterterrorism measures: 10 out of 10 (see methodology section).

Initial research did not uncover evidence that the state has instituted criminal or civil counterterrorism proceedings on the basis of engaging in principled humanitarian action in conflict zones involving terrorists. Nor did initial research uncover evidence that the state's domestic counterterrorism legislation had or has a reported "chilling effect" on principled humanitarian organizations.

Financial support via designated channel to Iraq and Syria in 2015 (to date) as a percentage of GDP: 2 out of 10 (see methodology section).

$0 \%$ (no financial assistance reportedly provided via the designated funding channel) (http://data. worldbank.org/indicator/NY.GDP.MKTP.CD and https://fts.unocha.org/pageloader.aspx?page=searchcustomsearch).

\section{RUSSIA}

\section{Compliance with five key foreign terrorist fighter elements of Resolution 2178 (2014)}

\section{Points allocated: $\mathbf{3 4}$ out of $\mathbf{5 0}$ (see methodology section).}

Preventing and suppressing foreign terrorist fighter travel: 6 out of 10 (see methodology section).

Assessment criterion i: 6 out of 8. Assessment criteria ii and iii: 0 out of 2: The Russian Criminal Code contains several provisions that could apply to foreign terrorist fighters, including Article 205 (Act of Terrorism) and Article 210 (Creation of a Criminal Group/Organization and Participation Therein) (http://www.state.gov/j/ct/rls/crt/2014/239406.htm). "Russia has a comprehensive counterterrorism legal framework that includes provisions of the Criminal Code and a law 'On Security on Transport.' Russian passports have enhanced security features, such as holographic images on the biographic data page, and a recent bill would require fingerprint data to be included in Russian passports. Older versions of Russian passports that do not contain these security features continue to be used, however, as passports may be valid for five or ten years. Border guards patrol air, land, and sea ports of entry, but the extent they are able to patrol all ports of entry is unclear. While border guards can collect biometric data at ports of entry, they do not do so on a regular basis." (http://www.state.gov/j/ct/rls/ crt/2014/239406.htm).

\section{Penalizing foreign terrorist fighter conduct: 6 out of 10 (see methodology section).}

On December 29, 2014, participation in ISIS activities became a criminal offense under Russian law. Russia also added two components to Article 205.1 of the Russian Criminal Code on "aiding and 
abetting terrorist activity," which criminalize the act of organizing terrorist financing, leading an act of terrorism, and leading an organization that conducts "terrorist crimes" (http://www.state.gov/j/ct/rls/ crt/2014/239406.htm).

Penalize funding to foreign terrorist fighters: 6 out of 10 (see methodology section).

"Russia is a member of the FATF and belongs to two FATF-style regional bodies. Russia has a comprehensive counterterrorism legal framework that includes provisions of the Criminal Code and a law 'On Money Laundering and Terrorist Financing.' Russia imposes administrative liability under its Administrative Code for legal entities that collect funds or provide legal services in the preparation, organization, or commission of a terrorist act. The penalty ranges from 10 million to 60 million rubles (approximately $\$ 166,000$ to one million U.S.). Russian banks must report suspicious transactions to the Federal Financial Monitoring Service (Rosfinmonitoring), which also receives reports from all nonprofit organizations. In 2014, Russia also enacted changes that assure tighter control over nonprofits and other non-commercial entities in Russia by lowering the reporting threshold to approximately $\$ 1,700$ U.S. for Russian non-governmental organizations that receive money and in-kind assistance from abroad. Russia does not use a risk-based approach towards its regulation of the nonprofit sector" (http://www.state.gov/j/ct/rls/crt/2014/239406.htm). "Russia maintains an International Counterterrorism Database (MBD) that holds information regarding terrorist events, subjects, organizations, and methods. International intelligence and law enforcement agencies can contribute information to this database. Russia cooperated with the FBI's investigation of the Boston Marathon bombing, as well as multilaterally on other counterterrorism issues" (http://www.state.gov/j/ct/rls/ crt/2014/239406.htm).

Penalize the facilitation of (including organization and recruitment of) foreign terrorist fighters: 6 out of 10 (see methodology section).

The Russian government uses its "anti-extremism" legislation to prosecute individuals and organizations, including the political opposition, independent media, and certain religious minorities, for crimes such as incitement to "religious discord" and "assistance to extremism" (http://www.state. gov/j/ct/rls/crt/2014/239406.htm).

Bring foreign terrorist fighters to "justice": 10 out of 10 (see methodology section).

"Russia took measures to address the issue of foreign terrorist fighters, which included law enforcement and judicial actions that resulted in the conviction of at least four Russian citizens who were known to have fought with militants against the Syrian government, and all of whom were sentenced to prison terms ranging from two to four years' imprisonment. Other terrorism cases have resulted in prison sentences ranging from two to life imprisonment" (http://www.state.gov/j/ct/rls/ $\mathrm{crt} / 2014 / 239406 . \mathrm{htm})$. A Russian official reports that over 300 criminal investigations have been opened against suspected ISIS fighters (http://www.rferl.org/content/islamic-state-russia-heightenedsecurity/26928550.html).

\title{
Support of five key aspects of principled humanitarian action in counterterrorism contexts
}

\author{
Points allocated: 29 out of 50 (see methodology section).
}


Knowability of anti-terrorism lists: 10 out of 10 (see methodology section).

Russia maintains a publicly available list of designated terrorists (available in Russian at http://www.fsb. $\mathrm{ru} / \mathrm{fsb} / \mathrm{npd} /$ terror.htm).

Ease of navigability and efficiency of the regulatory system: 5 out of 10 (see methodology section).

Initial research suggests that the relevant portions of the regulatory system are relatively challenging to navigate and/or relatively inefficient. For instance, NGOs face "burdensome" reporting requirements; NGOs must register with government officials if they wish to receive foreign funding and conduct political and/or advocacy activities, and consequently will be considered a "foreign agent" (http://www. icnl.org/research/monitor/russia.html).

Explicit exemptions from counterterrorism measures of principled humanitarian action: 0 out of 10 (see methodology section).

Initial research suggests that the domestic legislation, if any, limiting travel to conflict zones involving terrorists does not exempt staff of principled humanitarian organizations (expressly or as a subset of non-profit organizations, automatically or potentially through a petition/license); that domestic legislation, if any, applicable within the territory of the state and/or extraterritorially restricting engagement with terrorists does not exempt impartial wartime medical care for terrorists; and that relevant domestic legislation, if any, does not exempt other forms of principled humanitarian action in conflict zones involving terrorists.

No reported legal proceedings on the basis of principled humanitarian action in conflict zones involving terrorists nor reported "chilling effect" (self-imposed curtailment) of principled humanitarian action due to state counterterrorism measures: 10 out of 10 (see methodology section).

Initial research did not uncover evidence that the state has instituted criminal or civil counterterrorism proceedings on the basis of engaging in principled humanitarian action in conflict zones involving terrorists. Nor did initial research uncover evidence that the state's domestic counterterrorism legislation had or has a reported "chilling effect" on principled humanitarian organizations.

Financial support via designated channel to Iraq and Syria in 2015 (to date) as a percentage of GDP: 4 out of 10 (see methodology section).

0.00011\% (http://data.worldbank.org/indicator/NY.GDP.MKTP.CD and https://fts.unocha.org/ pageloader.aspx?page=search-customsearch).

\section{Saudi Arabia}

\section{Compliance with five key foreign terrorist fighter elements of Resolution 2178 (2014)}

\section{Points allocated: 39 out of $\mathbf{5 0}$ (see methodology section).}


Preventing and suppressing foreign terrorist fighter travel: 3 out of 10 (see methodology section) (assessment criteria i: 2 [out of 8]).

Assessment criterion i: 2 out of 8. Assessment criteria ii and iii: 1 out of 2: Royal Decree No. 44(a) of 2014 punishes Saudi citizens who join extremist organizations, participate in military operations with such organizations, and support those organizations either materially or by recruiting others to join them. These crimes are punishable by three to 20 years' imprisonment. If the individual is affiliated with the Saudi Armed Forces, the penalty for such crimes is increased to five to 30 years' imprisonment (http:// www.loc.gov/law/help/foreign-fighters/country-surveys.php). "The Saudi government improved border security in 2014 by using biometric systems, aerial reconnaissance, thermal imaging, and remote unattended sensors along the border region" (http://www.state.gov/j/ct/rls/crt/2014/239407.htm).

Penalizing foreign terrorist fighter conduct: 6 out of 10 (see methodology section).

Royal Decree No. 44(a) of 2014 punishes Saudi citizens who join extremist organizations, participate in military operations with such organizations, and support those organizations either materially or by recruiting others to join them. These crimes are punishable by three to 20 years' imprisonment. If the individual is affiliated with the Saudi Armed Forces, the penalty for such crimes is increased to five to 30 years' imprisonment (http://www.loc.gov/law/help/foreign-fighters/country-surveys.php).

Penalize funding to foreign terrorist fighters: 10 out of 10 (see methodology section).

Saudi Arabia is a member of the Middle East and North Africa FATF, a FATF-style regional body. The Saudi government has "affirmed its commitment to combating terrorist fundraising and sought to further establish itself as a regional leader in disrupting terrorist finance efforts in the region." It continued to provide specialized training for bankers, prosecutors, judges, customs officers, and other government and agency officials on terrorist financing. The 2014 Saudi counterterrorism law further outlines the Saudi government's ability to combat terrorist financing. It specifies that individuals who provide "financial or material donations to or funding of the extremist or terroristic organizations, factions, or groups" shall be punished with three to 20 years' imprisonment (http://www.aawsat. net/2014/03/article55329804/full-text-of-saudi-interior-ministry-statement-announcing-terrorist-list). "Despite these efforts, however, foreign charities with suspected links to terrorist groups continued to leverage social media to solicit funds from Saudi donors, a trend the government worked to combat" (http://www.state.gov/j/ct/rls/crt/2014/239407.htm). Saudi Arabia is a member of the Global Coalition to Counter ISIL. It continued to cooperate with the United States through information exchange programs (http://www.state.gov/j/ct/rls/crt/2014/239407.htm).

Penalize the facilitation of (including organization and recruitment of) foreign terrorist fighters: 10 out of 10 (see methodology section).

Royal Decree No. 44(a) of 2014 punishes Saudi citizens who join extremist organizations, participate in military operations with such organizations, and support those organizations either materially or by recruiting others to join them. These crimes are punishable by three to 20 years' imprisonment. If the individual is affiliated with the Saudi Armed Forces, the penalty for such crimes is increased to five to 30 years'imprisonment (http://www.loc.gov/law/help/foreign-fighters/country-surveys.php).

Bring foreign terrorist fighters to "justice": 10 out of 10 (see methodology section).

Saudi Arabia tracks, arrests, and prosecutes terrorist suspects through the Saudi General Investigations Directorate. In 2014, Saudi officials disrupted a more-than-70-member ISIL cell active in Saudi Arabia (http://www.state.gov/j/ct/rls/crt/2014/239407.htm). 


\section{Support of five key aspects of principled humanitarian action in counterterrorism contexts}

\section{Points allocated: 31 out of 50 (see methodology section).}

Knowability of anti-terrorism lists: 10 out of 10 (see methodology section).

In 2014, news sources reported that Saudi Arabia announced a terrorist list by royal decree (http:// www.al-monitor.com/pulse/security/2014/03/saudi-terrorism-list-syria-spark-new-conflicts.

html\#). The list is available through the Ministry of the Interior (http://www.moi.gov.sa/wps/portal/ investigationdepartment/).

Ease of navigability and efficiency of the regulatory system: 5 out of 10 (see methodology section).

Initial research suggests that the relevant portions of the regulatory system are relatively challenging to navigate and/or relatively inefficient. For instance, NGOs reportedly face considerable delays in the registration process, which can take years; government officials attend NGO meetings; and, reportedly, foreign funding is not permissible in practice, although it is not proscribed by law (http://www.icnl.org/ research/monitor/saudiarabia.html).

Explicit exemptions from counterterrorism measures of principled humanitarian action: 0 out of 10 (see methodology section).

Initial research suggests that the domestic legislation, if any, limiting travel to conflict zones involving terrorists does not exempt staff of principled humanitarian organizations (expressly or as a subset of non-profit organizations, automatically or potentially through a petition/license); that domestic legislation, if any, applicable within the territory of the state and/or extraterritorially restricting engagement with terrorists does not exempt impartial wartime medical care for terrorists; and that relevant domestic legislation, if any, does not exempt other forms of principled humanitarian action in conflict zones involving terrorists.

No reported legal proceedings on the basis of principled humanitarian action in conflict zones involving terrorists nor reported "chilling effect" (self-imposed curtailment) of principled humanitarian action due to state counterterrorism measures: 10 out of 10 (see methodology section).

Initial research did not uncover evidence that the state has instituted criminal or civil counterterrorism proceedings on the basis of engaging in principled humanitarian action in conflict zones involving terrorists. Nor did initial research uncover evidence that the state's domestic counterterrorism legislation had or has a reported "chilling effect" on principled humanitarian organizations.

Financial support via designated channel to Iraq and Syria in 2015 (to date) as a percentage of GDP: 6 out of 10 (see methodology section).

0.00158\% (http://data.worldbank.org/indicator/NY.GDP.MKTP.CD and https://fts.unocha.org/ pageloader.aspx?page=search-customsearch). 


\section{SWEDEN}

\section{Compliance with five key foreign terrorist fighter elements of Resolution 2178 (2014)}

\section{Points allocated: 31 out of $\mathbf{5 0}$ (see methodology section).}

Preventing and suppressing foreign terrorist fighter travel: 3 out of 10 (see methodology section).

Assessment criterion i: 2 out of 8. Assessment criteria ii and iii: 1 out of 2: Swedish law has no provisions that criminalize fighting for terrorist groups abroad (http://www.loc.gov/law/help/foreignfighters/country-surveys.php). The Swedish government is investigating how to enhance existing counterterrorism legislation to mitigate the risks posed by foreign terrorist fighters. Sweden uses the Schengen Information System II for information sharing, port of entry screening, lost and stolen passport information, and watchlisting. Under the auspices of the PNR agreement between the EU and the United States, Sweden collects and shares PNR information from commercial flights (http://www. state.gov/j/ct/rls/crt/2014/239406.htm).

Penalizing foreign terrorist fighter conduct: 6 out of 10 (see methodology section).

Swedish law has no provisions that criminalize fighting for terrorist groups abroad (http://www.loc. gov/law/help/foreign-fighters/country-surveys.php). Swedish law criminalizes incitement of terrorist acts, and providing terrorist training. Sweden is undertaking an internal investigation on how to implement the provisions of UNSCR 2178 , including the possibility of criminalizing the act of training with terrorist organizations or waging war on behalf of terrorist organizations (http://www.state.gov/j/ ct/rls/crt/2014/239406.htm).

Penalize funding to foreign terrorist fighters: 6 out of 10 (see methodology section).

"Sweden is a member of the FATF. In 2014, it passed legislation that allowed officials to halt transactions for two days if the transaction was suspected to be terrorist financing. Internal reports have indicated Sweden's vulnerability to many forms of terrorist financing...U.S. agencies worked with their Swedish counterparts for the exchange and evaluation of terrorist-related information. Sweden also cooperates and is active within the EU, UN, and Council of Europe on CVE and the recruitment of foreign terrorist fighters. Sweden is also a member of the Global Coalition to Counter ISIL. Sweden also participated in an ad hoc group of EU and other countries on foreign terrorist fighter issues" (http://www.state.gov/j/ ct/rls/crt/2014/239406.htm).

Penalize the facilitation of (including organization and recruitment of) foreign terrorist fighters: 6 out of 10 (see methodology section).

Swedish law criminalizes recruitment to terrorist organizations (http://www.state.gov/j/ct/rls/ crt/2014/239406.htm).

Bring foreign terrorist fighters to "justice": 10 out of 10 (see methodology section).

"Sweden's Security Service (SAPO) reported that it is conducting several 'pre-investigations' related 
to individuals who have returned from conflict areas with fighting experience. With respect to other terrorist-related crimes (incitement, recruitment, and providing terrorist training), only five people have been convicted under these laws, and only two convictions have stood following appeals. In all other prosecutions, evidence has proven inadequate to secure a conviction" (http://www.state.gov/j/ct/rls/ crt/2014/239406.htm).

\section{Support of five key aspects of principled humanitarian action in counterterrorism contexts}

\section{Points allocated: $\mathbf{3 8}$ out of $\mathbf{5 0}$ (see methodology section).}

Knowability of anti-terrorism lists: 10 out of 10 (see methodology section).

Sweden (through the Swedish police) maintains a terrorist list and list of terrorist symbols (for instance, see https://www.middleeastmonitor.com/news/europe/18439-sweden-including-palestinian-flagon-list-of-terrorist-symbols-a-mistake), and it also is a member of the EU, which maintains publicly available terrorist lists that encompass the provisions of the al-Qaeda sanctions and other relevant Security Council measures (http://www.consilium.europa.eu/en/policies/fight-against-terrorism/ terrorist-list/).

Ease of navigability and efficiency of the regulatory system: 10 out of 10 (see methodology section).

Initial research suggests that the relevant portions of the regulatory system are relatively easy to navigate and efficient (http://ec.europa.eu/citizenship/pdf/national_report_se_en.pdf).

Explicit exemptions from counterterrorism measures of principle humanitarian action: 0 out of 10 (see methodology section).

Initial research suggests that the domestic legislation, if any, limiting travel to conflict zones involving terrorists does not exempt staff of principled humanitarian organizations (expressly or as a subset of non-profit organizations, automatically or potentially through a petition/license); that domestic legislation, if any, applicable within the territory of the state and/or extraterritorially restricting engagement with terrorists does not exempt impartial wartime medical care for terrorists; and that relevant domestic legislation, if any, does not exempt other forms of principled humanitarian action in conflict zones involving terrorists. See also Department for Development Policy and the Ministry of Foreign Affairs (2010): "Humanitarian organisations should always maintain a clear division of roles between themselves as civilians on the one hand and armed groups and other parties to the conflict on the other. This approach is particularly important in areas where military forces operate."

No reported legal proceedings on the basis of principled humanitarian action in conflict zones involving terrorists nor reported "chilling effect" (self-imposed curtailment) of principled humanitarian action due to state counterterrorism measures: 10 out of 10 (see methodology section).

Initial research did not uncover evidence that the state has instituted criminal or civil counterterrorism proceedings on the basis of engaging in principled humanitarian action in conflict zones involving terrorists. Nor did initial research uncover evidence that the state's domestic counterterrorism legislation had or has a reported "chilling effect" on principled humanitarian organizations. 
Financial support via designated channel to Iraq and Syria in 2015 (to date) as a percentage of GDP: 8 out of 10 (see methodology section).

0.00641\% (http://data.worldbank.org/indicator/NY.GDP.MKTP.CD and https://fts.unocha.org/ pageloader.aspx?page=search-customsearch).

\section{TUNISIA}

\section{Compliance with five key foreign terrorist fighter elements of Resolution 2178 (2014)}

\section{Points allocated: 8 out of $\mathbf{5 0}$ (see methodology section).}

Preventing and suppressing foreign terrorist fighter travel: 0 out of 10 (see methodology section).

Assessment criterion i: 0 out of 8. Assessment criteria ii and iii: 0 out of 2: "Tunisia has an Automated Fingerprint Identification System (AFIS) and maintains fingerprint records for identification cards, criminal records, and latent prints. Tunisia does not currently share AFIS or biometric data with other countries. The government has undertaken a 'sweeping study of its options to modernize and strengthen its border security capabilities.' Border security remained a priority in 2014 and Tunisia collaborated with Algeria to stem the flow of weapons and insurgents across their borders with Libya" (http://www.state.gov/documents/organization/239631.pdf).

Penalizing foreign terrorist fighter conduct: 2 out of 10 (see methodology section).

Tunisia's counterterrorism law was passed in 2003, and it criminalizes acts aimed at "disturbing international peace and security" (Kent Roach, Comparative Counter-Terrorism Law, at 36). As of March 26, 2015, the Tunisian Parliament began considering a new law, which, among other things, would allow police to hold suspects in detention (incommunicado and pre-charge) for up to 15 days (current law allows the government to hold terrorism suspects for six days). The new law would also permit the death penalty for anyone convicted of a terrorist act resulting in death. It contains a "broad and ambiguous definition of terrorist activity," according to Human Rights Watch, which could allow the government to infringe upon its citizens' freedoms (http://www.hrw.org/news/2015/04/08/tunisiaflaws-revised-counterterrorism-bill). The law passed on July 24, 2015 (http://www.nytimes.com/ aponline/2015/07/25/world/middleeast/ap-ml-tunisia-anti-terror-law.html). See also Roach for 2014 definition of terrorism, which includes acts that "harm[] public or private property..."

\section{Penalize funding to foreign terrorist fighters: 2 out of 10 (see methodology section).}

"Tunisia is a member of the Middle East and North Africa FATF, a FATF-style regional body. Tunisia's financial intelligence unit has worked effectively over the past year to gather information to improve its efforts to combat money laundering and terrorist financing. The Tunisian Penal Code provides for the seizure of assets and property related to terrorist activities. While it freezes and confiscates assets, the timeframe varies depending on the case" (http://www.state.gov/documents/organization/239631.pdf). 
Penalize the facilitation of (including organization and recruitment of) foreign terrorist fighters: 2 out of 10 (see methodology section).

Initial research did not uncover evidence that the state has ensured that domestic laws and regulations establish serious criminal offenses sufficient to provide the ability to prosecute and penalize the willful organization, or other facilitation, including acts of recruitment, by their nationals or in their territories, of the travel of individuals who travel to a state other than their states of residence or nationality for the purpose of the perpetration, planning, preparation of, or participation in, terrorist acts or the provide or receiving of terrorist training.

Bring foreign terrorist fighters to "justice": 2 out of 10 (see methodology section).

According to the U.S. State Department, Tunisian security forces are "inexperienced in tackling terrorist threats," although the Ministries of Interior and Defense reportedly work well together, coordinating their efforts within Counterterrorism Task Forces established in the military exclusion zones (http:// www.state.gov/documents/organization/239631.pdf).

\section{Support of five key aspects of principled humanitarian action in counterterrorism contexts}

\section{Points allocated: 22 out of 50 (see methodology section).}

Knowability of anti-terrorism lists: 0 out of 10 (see methodology section).

Initial research did not uncover evidence that the state has established a domestic anti-terrorism list (at a minimum, a list implementing binding Security Council-imposed al-Qaeda-related sanctions) and/or made the requisite measures relating to that list publicly available.

Ease of navigability and efficiency of the regulatory system: 10 out of 10 (see methodology section).

Initial research suggests that the relevant portions of the regulatory system are relatively easy to navigate and efficient (http://www.icnl.org/research/library/files/Tunisia/88-2011-Eng.pdf; http://www. icnl.org/research/trends/trends3-1.html).

Explicit exemptions from counterterrorism measures of principled humanitarian action: 0 out of 10 (see methodology section).

Initial research suggests that the domestic legislation, if any, limiting travel to conflict zones involving terrorists does not exempt staff of principled humanitarian organizations (expressly or as a subset of non-profit organizations, automatically or potentially through a petition/license); that domestic legislation, if any, applicable within the territory of the state and/or extraterritorially restricting engagement with terrorists does not exempt impartial wartime medical care for terrorists; and that relevant domestic legislation, if any, does not exempt other forms of principled humanitarian action in conflict zones involving terrorists. 
No reported legal proceedings on the basis of principled humanitarian action in conflict zones involving terrorists nor reported "chilling effect" (self-imposed curtailment) of principled humanitarian action due to state counterterrorism measures: 10 out of 10 (see methodology section).

Initial research did not uncover evidence that the state has instituted criminal or civil counterterrorism proceedings on the basis of engaging in principled humanitarian action in conflict zones involving terrorists. Nor did initial research uncover evidence that the state's domestic counterterrorism legislation had or has a reported "chilling effect" on principled humanitarian organizations.

Financial support via designated channel to Iraq and Syria in 2015 (to date) as a percentage of GDP: 2 out of 10 (see methodology section).

0\% (no financial assistance reportedly provided via the designated funding channel) (http://data. worldbank.org/indicator/NY.GDP.MKTP.CD and https://fts.unocha.org/pageloader.aspx?page=searchcustomsearch).

\section{TURKEY}

\section{Compliance with five key foreign terrorist fighter elements of Resolution 2178 (2014)}

\section{Points allocated: 21 out of 50 (see methodology section).}

Preventing and suppressing foreign terrorist fighter travel: 5 out of 10 (see methodology section).

Assessment criterion i: 4 out of 8. Assessment criteria ii and iii: 1 out of 2: As of 2014, the Turkish government is considering how to implement UNSCR 2178. Currently, Turkish counterterrorism law remains focused on domestic threats posed by terrorist groups such as the PKK. Terrorism, under Turkish law, is relatively narrowly defined as a crime targeting the Turkish state or Turkish citizens (http://www.state.gov/j/ct/rls/crt/2014/239406.htm). "In 2014, Turkish officials intensified efforts to interdict the travel of suspected foreign terrorist fighters through Turkey to and from Syria and Iraq, including the development and implementation of a 'banned from entry list,' which aims to prevent travel into Turkey by individuals identified by foreign governments and internal security units as potential foreign terrorist fighters; and the deployment of 'Risk Analysis Units' to detect suspected foreign terrorist fighters at airports, land border crossings, and border cities. Risk Analysis Units exist at 11 major ports of entry, including international and domestic airports, land border crossings, and border cities...Turkey's border security challenges, however, continued to be aggravated by its failure to impose visa requirements for certain major foreign terrorist fighter source countries such as Libya." (http://www.state.gov/j/ct/rls/crt/2014/239406.htm).

Penalizing foreign terrorist fighter conduct: 2 out of 10 (see methodology section).

Initial research did not uncover evidence that the state ensures that domestic laws and regulations establish serious criminal offenses sufficient to provide the ability to prosecute and penalize their nationals and other individuals who travel or attempt to travel to a state other than their states of 
residence or nationality, for the purpose of perpetration, planning, or preparation of, or participation in, terrorist acts, or providing or receiving terrorist training. Turkish counterterrorism law remains focused on domestic threats posed by terrorist groups such as the PKK. Terrorism, under Turkish law, is relatively narrowly defined as a crime targeting the Turkish state or Turkish citizens (http://www.state. gov/j/ct/rls/crt/2014/239406.htm).

Penalize funding to foreign terrorist fighters: 2 out of 10 (see methodology section).

"Turkey is a member of the FATF and an observer of a FATF-style regional body. No terrorist finance cases were prosecuted in 2014. While Turkey may freeze assets of organizations, it remains unknown whether any assets have actually been frozen. The nonprofit sector is not audited on a regular basis for terrorist financing vulnerabilities." (http://www.state.gov/j/ct/rls/crt/2014/239406.htm). Turkey is an active member of the Global Coalition to Counter ISIL, and it co-chairs the Global Counterterrorism Forum along with the United States. According to the U.S. State Department, cooperation with other source countries increased during 2014 in response to the foreign terrorist fighter threat, with both Turkey and source countries seeking improvements in information sharing (http://www.state.gov/j/ct/ $\mathrm{rls} / \mathrm{crt} / 2014 / 239406 . \mathrm{htm})$.

Penalize the facilitation of (including organization and recruitment of) foreign terrorist fighters: 2 out of 10 (see methodology section).

Initial research did not uncover evidence that the state has ensured that domestic laws and regulations establish serious criminal offenses sufficient to provide the ability to prosecute and penalize the willful organization, or other facilitation, including acts of recruitment, by their nationals or in their territories, of the travel of individuals who travel to a state other than their states of residence or nationality for the purpose of the perpetration, planning, preparation of, or participation in, terrorist acts or the provide or receiving of terrorist training.

Bring foreign terrorist fighters to "justice": 10 out of 10 (see methodology section).

Three individuals identified as members of ISIL killed a police officer, and were subsequently captured and remained in custody at the end of 2014 (http://www.state.gov/j/ct/rls/crt/2014/239406.htm).

\section{Support of five key aspects of principled humanitarian action in counterterrorism contexts}

\section{Points allocated: 27 out of $\mathbf{5 0}$ (see methodology section).}

Knowability of anti-terrorism lists: 10 out of 10 (see methodology section).

The Turkish government does maintain a publicly available list of terrorist organizations (http://www. egm.gov.tr/en/pages/terrorist_organizations.aspx).

Ease of navigability and efficiency of the regulatory system: 5 out of 10 (see methodology section).

Initial research suggests that the relevant portions of the regulatory system are relatively challenging to navigate and/or relatively inefficient. For instance, NGOs have "cumbersome" reporting requirements, and must notify the government when they use foreign funding or receive grants from international organizations (http://www.icnl.org/research/monitor/turkey.html). 
Explicit exemptions from counterterrorism measures of principled humanitarian action: 0 out of 10 (see methodology section).

Initial research suggests that the domestic legislation, if any, limiting travel to conflict zones involving terrorists does not exempt staff of principled humanitarian organizations (expressly or as a subset of non-profit organizations, automatically or potentially through a petition/license); that domestic legislation, if any, applicable within the territory of the state and/or extraterritorially restricting engagement with terrorists does not exempt impartial wartime medical care for terrorists; and that relevant domestic legislation, if any, does not exempt other forms of principled humanitarian action in conflict zones involving terrorists.

No reported legal proceedings on the basis of principled humanitarian action in conflict zones involving terrorists nor reported "chilling effect" (self-imposed curtailment) of principled humanitarian action due to state counterterrorism measures: 10 out of 10 (see methodology section).

Initial research did not uncover evidence that the state has instituted criminal or civil counterterrorism proceedings on the basis of engaging in principled humanitarian action in conflict zones involving terrorists. Nor did initial research uncover evidence that the state's domestic counterterrorism legislation had or has a reported "chilling effect" on principled humanitarian organizations.

Financial support via designated channel to Iraq and Syria in 2015 (to date) as a percentage of GDP: 2 out of 10 (see methodology section).

0\% (no financial assistance reportedly provided via the designated funding channel) (http://data. worldbank.org/indicator/NY.GDP.MKTP.CD and https://fts.unocha.org/pageloader.aspx?page=searchcustomsearch).

\section{United Arab Emirates}

\section{Compliance with five key foreign terrorist fighter elements of Resolution 2178 (2014)}

\section{Points allocated: 24 out of $\mathbf{5 0}$ (see methodology section).}

Preventing and suppressing foreign terrorist fighter travel: 8 out of 10 (see methodology section).

Assessment criterion i: 8 out of 8. Assessment criteria ii and iii: 0 out of 2: Initial research did not uncover evidence that the state prevents entry or transit through their territory of FTFs, nor did our initial research uncover evidence that the state prevents the movement of terrorists or terrorist groups by effective border controls and controls on issuance of identity papers and travel documents.

\section{Penalizing foreign terrorist fighter conduct: 10 out of 10 (see methodology section).}

Under Article 10 of UAE Law 1 of 2004, amended in 2014, individuals cooperating with or joining organizations located outside the UAE that use terrorism to achieve their goals are punishable with up to life imprisonment. If an individual receives military training by this kind of organization, they would 
be punished by a minimum ten-year prison sentence. If the individual participates in any terrorist activities, they would be punished with life imprisonment (http://www.loc.gov/law/help/foreignfighters/country-surveys.php).

Penalize funding to foreign terrorist fighters: 2 out of 10 (see methodology section).

Initial research did not uncover evidence that the state has ensured that domestic laws and regulations establish serious criminal offenses sufficient to provide the ability to prosecute and penalize the willful provision or collection of funds by their nationals or in their territories.

Penalize the facilitation of (including organization and recruitment of) foreign terrorist fighters: 2 out of 10 (see methodology section).

Initial research did not uncover evidence that the state has ensured that domestic laws and regulations establish serious criminal offenses sufficient to provide the ability to prosecute and penalize the willful organization, or other facilitation, including acts of recruitment, by their nationals or in their territories, of the travel of individuals who travel to a state other than their states of residence or nationality for the purpose of the perpetration, planning, preparation of, or participation in, terrorist acts or the provide or receiving of terrorist training.

Bring foreign terrorist fighters to "justice": 2 out of 10 (see methodology section).

Initial research did not uncover evidence that the state has ensured that any person who participates in the financing, planning, preparation, or perpetration of terrorist acts or in supporting terrorist acts is brought to justice.

\section{Support of five key aspects of principled humanitarian action in counterterrorism contexts}

\section{Points allocated: $\mathbf{3 5}$ out of $\mathbf{5 0}$ (see methodology section).}

Knowability of anti-terrorism lists: 10 out of 10 (see methodology section).

The UAE maintains a publicly available list of terrorist groups and organizations (http://www. thenational.ae/uae/government/list-of-groups-designated-terrorist-organisations-by-the-uae).

Ease of navigability and efficiency of the regulatory system: 5 out of 10 (see methodology section).

Initial research suggests that the relevant portions of the regulatory system are relatively challenging to navigate and/or relatively inefficient. For instance, news reports indicate that the UAE has previously taken steps to limit the travel and registration of individuals affiliated with foreign NGOs (http:// foreignpolicy.com/2012/04/05/exclusive-uae-detains-foreign-ngo-workers/).

Explicit exemptions from counterterrorism measures of principled humanitarian action: 0 out of 10 (see methodology section).

Initial research suggests that the domestic legislation, if any, limiting travel to conflict zones involving terrorists does not exempt staff of principled humanitarian organizations (expressly or as a subset of non-profit organizations, automatically or potentially through a petition/license); that domestic 
legislation, if any, applicable within the territory of the state and/or extraterritorially restricting engagement with terrorists does not exempt impartial wartime medical care for terrorists; and that relevant domestic legislation, if any, does not exempt other forms of principled humanitarian action in conflict zones involving terrorists.

No reported legal proceedings on the basis of principled humanitarian action in conflict zones involving terrorists nor reported "chilling effect" (self-imposed curtailment) of principled humanitarian action due to state counterterrorism measures: 10 out of 10 (see methodology section).

Initial research did not uncover evidence that the state has instituted criminal or civil counterterrorism proceedings on the basis of engaging in principled humanitarian action in conflict zones involving terrorists. Nor did initial research uncover evidence that the state's domestic counterterrorism legislation had or has a reported "chilling effect" on principled humanitarian organizations.

Financial support via designated channel to Iraq and Syria in 2015 (to date) as a percentage of GDP: 10 out of 10 (see methodology section).

0.01317\% (http://data.worldbank.org/indicator/NY.GDP.MKTP.CD and https://fts.unocha.org/ pageloader.aspx?page=search-customsearch).

\section{UNITED KINGDOM}

\section{Compliance with five key foreign terrorist fighter elements of Resolution 2178 (2014)}

\section{Points allocated: $\mathbf{4 3}$ out of $\mathbf{5 0}$ (see methodology section).}

Preventing and suppressing foreign terrorist fighter travel: 7 out of 10 (see methodology section).

Assessment criterion i: 6 out of 8. Assessment criteria ii and iii: 1 out of 2: Under the Terrorism Act, the police may take terrorism prevention and investigation measures, which are restrictive measures imposed on individuals, and can include the requirement to reside at a specific property and limitations on travel (http://www.loc.gov/law/help/foreign-fighters/country-surveys.php). In 2015, a new law obliges teachers, health care workers, and local government employees to inform law enforcement agencies if they suspect a young person is being radicalized (http://www. washingtonpost.com/world/europe/ten-years-after-77-bombings-britain-is-split-over-how-to-fightextremism/2015/07/03/html). In July 2014, the UK enacted the Antisocial Behavior Crime and Policing Act, which amended the port and border security powers of the Terrorism Act 2000, increasing the protection of individual freedoms during counterterrorism-related border stops. (http://www.state. $\mathrm{gov} / \mathrm{j} / \mathrm{ct} / \mathrm{rls} / \mathrm{crt} / 2014 / 239406 . \mathrm{htm})$. The police have the authority to stop and question individuals they suspect of being terrorists at ports and borders. The Home Secretary can reportedly use the Royal Prerogative to strip a person of their passport and thereby disrupt any overseas travel. News sources report that the Home Secretary has 23 passports under this power. The Secretary of State, under the British Nationality Act, can deprive a person of their British citizenship, unless it would render them stateless (http://www.loc.gov/law/help/foreign-fighters/country-surveys.php). The Counter-Terrorism and Security Act 2015 allows for, among other enhanced counterterrorism powers, the seizure and 
temporary retention of travel documents if a person is suspected of leaving the country "in connection with terrorism-related activity." (http://www.legislation.gov.uk/ukpga/2015/6/section/1/enacted).

Penalizing foreign terrorist fighter conduct: 10 out of 10 (see methodology section).

British law prohibits any British national to travel abroad to commit or prepare a terrorist offense, or to obtain training in terrorism, and suspects may be prosecuted for other terrorist acts, even if committed overseas. Any acts to prepare, or to assist others to prepare for acts of terrorism are also criminal offenses, punishable by up to life imprisonment (http://www.loc.gov/law/help/foreign-fighters/ country-surveys.php). Under Section 54 of the Terrorism Act 2000, weapons training is punishable by a maximum of ten years' imprisonment, a fine, or both.

Penalize funding to foreign terrorist fighters: 10 out of 10 (see methodology section).

"The UK is an active member of the FATF, and has observer or cooperating status with five regional FATF bodies. The UK amended its Terrorism Act 2000 in December 2014, to implement the freezing of assets in relation to terrorist offenses. The Protection of Charities Bill, introduced in 2014, would enable the Charities Commission to 'more effectively counter terrorist financing in the nonprofit sector.'The UK seizes assets, freezes assets, as well as prosecutes individuals involved in the financing of terrorism: since 2001, 48 individuals have been charged, and 17 have been convicted. It has placed asset freezes on individuals (including six ISIL-affiliated individuals in 2014). The UK Charities Commission also works to counter terrorist financing, and of the regulator's 85 open compliance cases as of October 2014, 37 are Syria-related investigations. Charities have a duty to report suspicious activities under Section 19 of the Terrorism Act 2000" (http://www.state.gov/j/ct/rls/crt/2014/239406.htm). "The UK is an active member of the Global Coalition to Counter ISIL. In September 2014, the UK ordered the extradition of a UK resident to the United States to face terrorism charges. This case provides one example of the cooperation between the U.S. Department of Justice and the Metropolitan Police Extradition Unit. The UK distributes a list of all UK-designated terrorists and terrorist entities to 15,000 institution subscribers, mainly in the UK and its territories overseas" (http://www.state.gov/j/ct/rls/ crt/2014/239406.htm).

Penalize the facilitation of (including organization and recruitment of) foreign terrorist fighters: 6 out of 10 (see methodology section).

The Terrorism Act 2000 prohibits the direction of terrorist organizations, which is punishable by life imprisonment (Section 56). The Terrorism Act 2000 also prohibits the provision of support for proscribed organizations, to include actions other than the provision of money or other property (1)(b). A person who arranges, manages, or assists with arranging or managing meetings to support or further the activities of a proscribed organization may be punished by a maximum of ten years' imprisonment, a fine, or both.

Bring foreign terrorist fighters to "justice": 10 out of 10 (see methodology section).

"In 2014, police charged at least 16 people with terrorism-related offenses after they had returned from either Syria or Iraq. In October 2014, two individuals were arrested related to violent extremism in Syria, one of them having been suspected of attending a terrorist training camp, and in November, police arrested four men for suspected terrorism as part of 'an ongoing investigation into Islamistrelated terrorism.' Additionally, two individuals were imprisoned for three and four and a half years, respectively, for conspiring to attend a terrorist training camp in Syria (these were the first Britons imprisoned after returning from Syria or Iraq)" (http://www.state.gov/j/ct/rls/crt/2014/239406.htm). 


\section{Support of five key aspects of principled humanitarian action in counterterrorism contexts}

\section{Points allocated: 35 out of 50 (see methodology section).}

Knowability of anti-terrorism lists: 10 out of 10 (see methodology section).

The UK maintains a publicly available list of proscribed terrorist groups and organizations (https:// www.gov.uk/government/publications/current-list-of-designated-persons-terrorism-and-terroristfinancing).

Ease of navigability and efficiency of the regulatory system: 10 out of 10 (see methodology section).

The Charity Commission oversees the operation and registration of most charities operating in the UK (some charities are exempt from registration) (https://www.gov.uk/topic/running-charity/setting-up, https://www.gov.uk/government/organisations/charity-commission/about).

Explicit exemptions from counterterrorism measures of principled humanitarian action: 0 out of 10 (see methodology section).

Initial research suggests that the domestic legislation, if any, limiting travel to conflict zones involving terrorists does not exempt staff of principled humanitarian organizations (expressly or as a subset of non-profit organizations, automatically or potentially through a petition/license); that domestic legislation, if any, applicable within the territory of the state and/or extraterritorially restricting engagement with terrorists does not exempt impartial wartime medical care for terrorists; and that relevant domestic legislation, if any, does not exempt other forms of principled humanitarian action in conflict zones involving terrorists.

No reported legal proceedings on the basis of principled humanitarian action in conflict zones involving terrorists nor reported "chilling effect" (self-imposed curtailment) of principled humanitarian action due to state counterterrorism measures: 5 out of 10 (see methodology section).

Initial research did not uncover evidence that the state has instituted criminal or civil counterterrorism proceedings on the basis of engaging in principled humanitarian action in conflict zones involving terrorists. Yet "[s]ome humanitarian actors reported that counter-terrorism legislation in countries such as ... the [United Kingdom] ... as well as restrictions in funding agreements, had a 'chilling effect."' (https://docs.unocha.org/sites/dms/documents/ct_study_full_report.pdf).

Financial support via designated channel to Iraq and Syria in 2015 (to date) as a percentage of GDP: 10 out of 10 (see methodology section).

0.01254\% (http://data.worldbank.org/indicator/NY.GDP.MKTP.CD and https://fts.unocha.org/ pageloader.aspx?page=search-customsearch). 


\section{United States}

\section{Compliance with five key foreign terrorist fighter elements of Resolution 2178 (2014)}

\section{Points allocated: 46 out of 50 (see methodology section).}

Preventing and suppressing foreign terrorist fighter travel: 10 out of 10 (see methodology section).

Assessment criterion i: 8 out of 8. Assessment criteria ii and iii: 2 out of 2: The U.S. State Department hosts the interagency Center for Strategic Counterterrorism Communications (CSCC) to counter recruitment and radicalization online through counter-messaging. CSCC currently works on a campaign against Syria and Iraq-based terrorists' online messaging to affect their ability to recruit foreign terrorist fighters (https://www.whitehouse.gov/the-press-office/2014/09/24/fact-sheet-comprehensiveus-government-approach-foreign-terrorist-fighte). The U.S. Department of Homeland Security has mandated advanced screening measures at certain overseas airports, and it has strengthened other measures to prevent and ensure lawful travel, including enhancing the security of the Visa Waiver Program by making changes to the Electronic System for Travel Authorization (ESTA). DHS now requires additional data to improve its ability to screen prospective visa waiver program travelers (https:// www.washingtoninstitute.org/uploads/Documents/other/AlphaStatement20150202.pdf). The FBI's Terrorist Screening Center has information sharing agreements with over 40 international partners, which helps identify and share terrorist activity. The U.S. Department of Homeland Security uses travel information like Advance Passenger Information and Passenger Name Record data to identify known and previously unknown foreign terrorist fighters (https://www.whitehouse.gov/the-pressoffice/2014/09/24/fact-sheet-comprehensive-us-government-approach-foreign-terrorist-fighte).

Penalizing foreign terrorist fighter conduct: 10 out of 10 (see methodology section).

U.S. law criminalizes the provision of material support or resources to terrorists, to include any tangible or intangible property; service, including currency or monetary instruments or financial securities; lodging; training; expert advice or assistance; safehouses; false documentation or identification; communications equipment; facilities; weapons; lethal substances; explosives; personnel (one or more individuals who may be or include oneself); and transportation. The only exceptions to this prohibition are medicine and religious materials. Persons convicted of material support to a terrorist organization may be punished with 15 years' imprisonment. (18 U.S.C. 2339A and B).

Penalize funding to foreign terrorist fighters: 10 out of 10 (see methodology section).

U.S. law criminalizes the provision of material support or resources to terrorists, to include any tangible or intangible property; service, including currency or monetary instruments or financial securities; lodging; training; expert advice or assistance; safehouses; false documentation or identification; communications equipment; facilities; weapons; lethal substances; explosives; personnel (one or more individuals who may be or include oneself); and transportation. The only exceptions to this prohibition are medicine and religious materials. Persons convicted of material support to a terrorist organization 
may be punished with 15 years' imprisonment. (18 U.S.C. 2339A and B). The United States provided evidentiary support and expert testimony in the German trial of four members of an al-Qaida terrorist cell (http://www.state.gov/j/ct/rls/crt/2014/239406.htm). The United States also states that it employs a "whole-of-government outreach effort with foreign partners to highlight the threat posed by foreign terrorist fighters." The U.S. State Department appointed a senior adviser for partner engagement on Syria foreign fighters to engage with other nations to "prioritize the threat, address vulnerabilities, and adapt to prevent and interdict foreign terrorist fighters" (https://www.whitehouse.gov/the-pressoffice/2014/09/24/fact-sheet-comprehensive-us-government-approach-foreign-terrorist-fighte).

Penalize the facilitation of (including organization and recruitment of) foreign terrorist fighters: 6 out of 10 (see methodology section).

The United States bans foreign military recruitment (18 U.S.C. 959); however, the statute does not specifically mention FTFs (at least as FTFs are defined in Security Council Resolution 2178).

Bring foreign terrorist fighters to "justice": 10 out of 10 (see methodology section).

The United States has prosecuted many individuals under the material support law (see, e.g., http:// foreignpolicy.com/2015/01/14/jihadi_love_does_us_law_prohibit_marrying_an_isis_fighter/).

\section{Support of five key aspects of principled humanitarian action in counterterrorism contexts}

\section{Points allocated: $\mathbf{3 7 . 5}$ out of 50 (see methodology section).}

Knowability of anti-terrorism lists: 10 out of 10 (see methodology section).

The United States maintains several publicly available domestic terrorist lists through various government agencies (see, e.g., http://www.state.gov/j/ct/list/ and http://www.treasury.gov/resourcecenter/sanctions/SDN-List/Pages/default.aspx).

Ease of navigability and efficiency of the regulatory system: 10 out of 10 (see methodology section).

NGOs seeking to operate in areas that may also be the target of U.S. sanctions must apply for a license to operate in those areas. As part of the review of the license application, OFAC may conduct background investigations of key personnel. (http://blogs.law.harvard.edu/cheproject/files/2012/10/ CHE-Project-OFAC-Licensing.pdf).

Explicit exemptions from counterterrorism measures of principled humanitarian action: 4.5 out of 10 (see methodology section).

The U.S. material support law exempts only the provision of "medicine and religious materials" (18 U.S.C. 2339 A and B). Also, as noted above, NGOs seeking to operate in areas that may also be the target of U.S. sanctions (including certain terrorism-related sanctions) must apply for a license to operate in those areas. 
No reported legal proceedings on the basis of principled humanitarian action in conflict zones involving terrorists nor reported "chilling effect" (self-imposed curtailment) of principled humanitarian action due to state counterterrorism measures: 5 out of 10 (see methodology section).

Initial research did not uncover evidence that the state has instituted criminal or civil counterterrorism proceedings on the basis of engaging in principled humanitarian action in conflict zones involving terrorists; while a number of counterterrorism prosecutions of and civil proceedings against (putative) "humanitarian" organizations and their personnel have occurred, an initial assessment of the available evidence does not confirm (or disconfirm) whether those organizations necessarily comported with the humanitarian principles of humanity, neutrality, independence, and impartiality. Further research in this area would be desirable. "Chilling effects" from the state's counterterrorism measures on humanitarian assistance have been reported (see, e.g., "The Chilling Effect of the 'Material Support' Law on Humanitarian Aid: Causes, Consequences, and Reforms," http://harvardnsj.org/wp-content/ uploads/2013/01/Vol-4-Adelsberg-Pitts-Shebaya.pdf; https://docs.unocha.org/sites/dms/documents/ ct_study_full_report.pdf).

Financial support via designated channel to Iraq and Syria in 2015 (to date) as a percentage of GDP: 8 out of 10 (see methodology section).

0.00483\% (http://data.worldbank.org/indicator/NY.GDP.MKTP.CD and https://fts.unocha.org/ pageloader.aspx?page=search-customsearch).

\section{UZBEKISTAN}

\section{Compliance with five key foreign terrorist fighter elements of Resolution 2178 (2014)}

\section{Points allocated: 16 out of 50 (see methodology section).}

Preventing and suppressing foreign terrorist fighter travel: 4 out of 10 (see methodology section).

Assessment criterion i: 4 out of 8. Assessment criteria ii and iii: 0 out of 2: Initial research did not uncover evidence that the state prevents entry or transit through their territory of FTFs, nor did our research uncover evidence that the state prevents the movement of terrorists or terrorist groups by effective border controls and controls on issuance of identity papers and travel documents.

Penalizing foreign terrorist fighter conduct: 6 out of 10 (see methodology section).

Uzbekistan's president has warned citizens who leave the country to join Islamic extremist groups and train at terrorist camps that if they return home, they will be imprisoned for five to seven years (http:// www.rferl.org/content/uzbekistan-imu-terrorism/25241539.html).

Penalize funding to foreign terrorist fighters: 2 out of 10 (see methodology section).

Initial research did not uncover evidence that the state has ensured that domestic laws and regulations establish serious criminal offenses sufficient to provide the ability to prosecute and penalize the willful 
provision or collection of funds by their nationals or in their territories.

Penalize the facilitation of (including organization and recruitment of) foreign terrorist fighters: 2 out of 10 (see methodology section).

Initial research did not uncover evidence that the state has ensured that domestic laws and regulations establish serious criminal offenses sufficient to provide the ability to prosecute and penalize the willful organization, or other facilitation, including acts of recruitment, by their nationals or in their territories, of the travel of individuals who travel to a state other than their states of residence or nationality for the purpose of the perpetration, planning, preparation of, or participation in, terrorist acts or the provide or receiving of terrorist training.

Bring foreign terrorist fighters to "justice": 2 out of 10 (see methodology section).

Individuals who know about potential terrorist activities and do not inform authorities may be imprisoned (http://www.loc.gov/law/help/foreign-fighters/country-surveys.php\#Uzbekistan).

\section{Support of five key aspects of principled humanitarian action in counterterrorism contexts}

\section{Points allocated: 17 out of $\mathbf{5 0}$ (see methodology section).}

Knowability of anti-terrorism lists: 0 out of 10 (see methodology section).

Initial research did not uncover evidence that the state has established a domestic anti-terrorism list (at a minimum, a list implementing binding Security Council-imposed al-Qaeda-related sanctions) and/or made the requisite measures relating to that list publicly available..

Ease of navigability and efficiency of the regulatory system: 5 out of 10 (see methodology section).

"NGOs are required to register with the Uzbek government, and the registration process and associated fees can be lengthy, cost-prohibitive, and opaque. On March 10, 2014, the Government approved the new Regulation on Procedure on State Registration of Non-Governmental and Non-Commercial Organizations (CSO Regulation). The CSO Regulation establishes a simplified registration procedure for non-governmental and non-commercial organizations (CSOs) and makes reports to the Ministry of Justice (MoJ) annual instead of quarterly, further simplifying reporting for Uzbek CSOs. The government also places limitations on NGOs, including foreign funding" (http://www.icnl.org/research/ monitor/uzbekistan.html).

Explicit exemptions from counterterrorism measures of principled humanitarian action: 0 out of 10 (see methodology section).

Initial research suggests that the domestic legislation, if any, limiting travel to conflict zones involving terrorists does not exempt staff of principled humanitarian organizations (expressly or as a subset of non-profit organizations, automatically or potentially through a petition/license); that domestic legislation, if any, applicable within the territory of the state and/or extraterritorially restricting engagement with terrorists does not exempt impartial wartime medical care for terrorists; and that 
relevant domestic legislation, if any, does not exempt other forms of principled humanitarian action in conflict zones involving terrorists.

No reported legal proceedings on the basis of principled humanitarian action in conflict zones involving terrorists nor reported "chilling effect" (self-imposed curtailment) of principled humanitarian action due to state counterterrorism measures: 10 out of 10 (see methodology section).

Initial research did not uncover evidence that the state has instituted criminal or civil counterterrorism proceedings on the basis of engaging in principled humanitarian action in conflict zones involving terrorists. Nor did initial research uncover evidence that the state's domestic counterterrorism legislation had or has a reported "chilling effect" on principled humanitarian organizations.

Financial support via designated channel to Iraq and Syria in 2015 (to date) as a percentage of GDP: 2 out of 10 (see methodology section).

$0 \%$ (no financial assistance reportedly provided via the designated funding channel) (http://data. worldbank.org/indicator/NY.GDP.MKTP.CD and https://fts.unocha.org/pageloader.aspx?page=searchcustomsearch). 


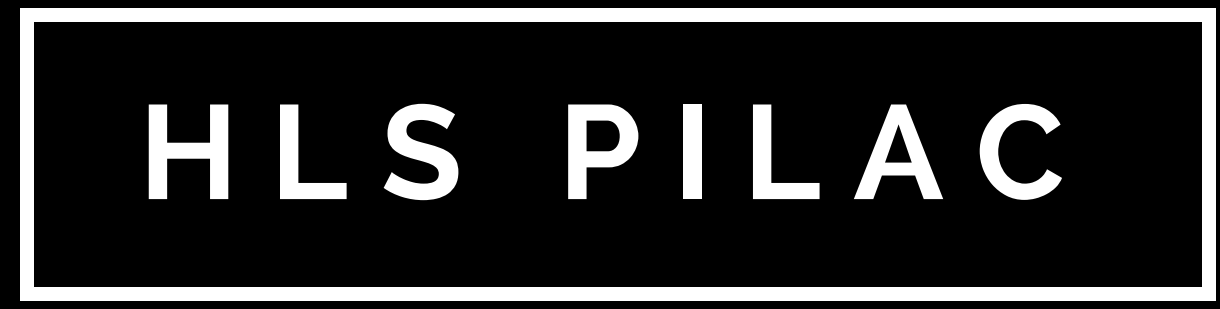

PILAC.LAW.HARVARD.EDU 